Food and Agriculture
Organization of the
United Nations

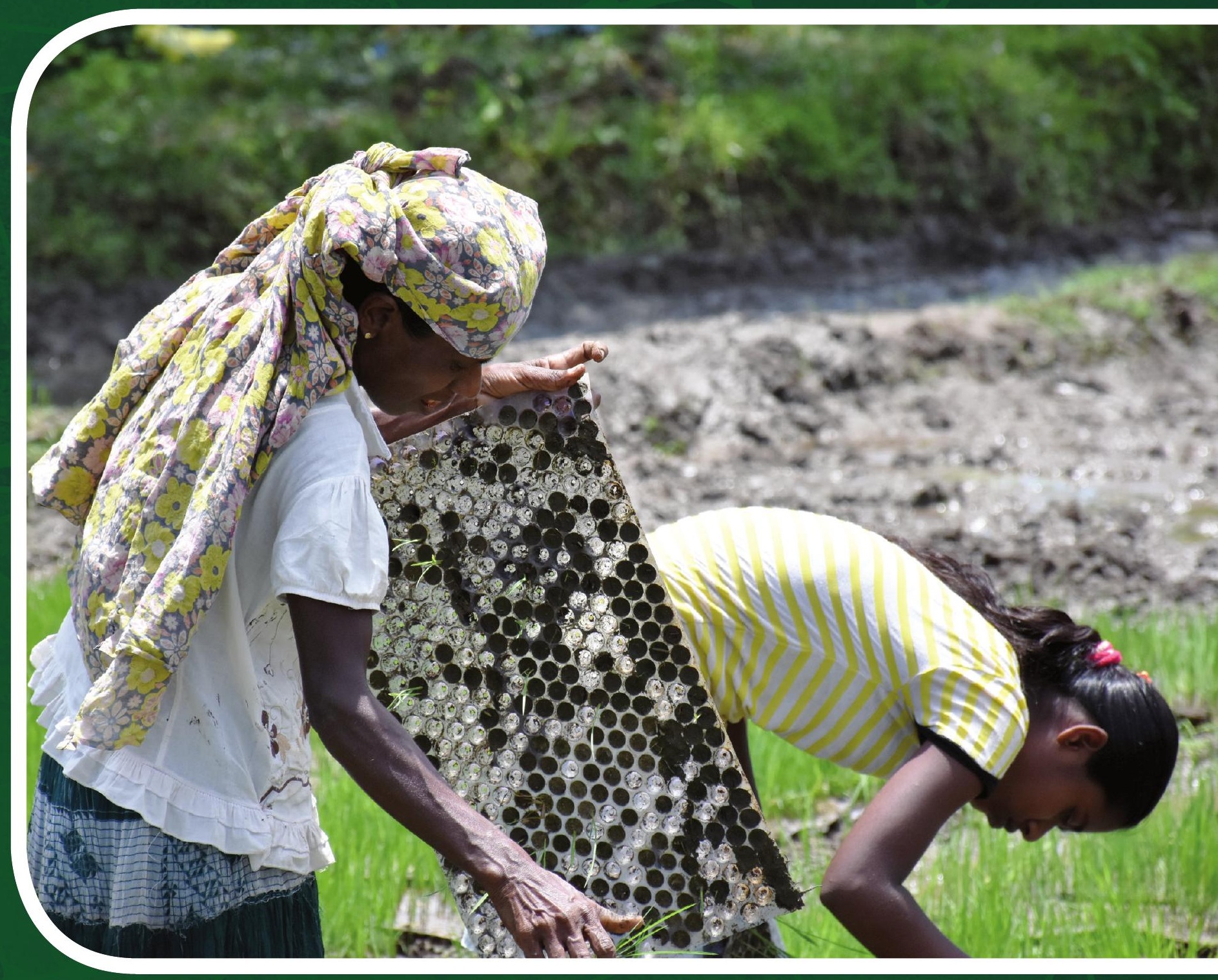

\title{
Olimate change impacts on crops in Sri Lanka
}





\section{Climate change impacts on crops in Sri Lanka}

Prepared by

Ruwanga Amarasingha, Buddhi Marambe and Lalith Suriyagoda

Faculty of Agriculture, University of Peradeniya, Sri Lanka

Ranjith Punyawardena

Natural Resources Management Centre

Department of Agriculture, Sri Lanka

Rasanayake Herath

Socio Economics and Planning Centre

Department of Agriculture, Sri Lanka

Shiromani Jayawardena, Preethika Jayakody

Department of Meteorology, Sri Lanka

Maria Raffaella Vuolo, Mariko Fujisawa, Ana Heureux, Jorge Alvar-Beltrán and Hideki Kanamaru

Food and Agriculture Organization of the United Nations, Italy

Rodrigo Manzanas

Department of Applied Mathematics and Computer Science,

University of Cantabria, Spain

Marco Acutis

University of Milan, Italy

Olivier Crespo

University of Cape Town, South Africa

Food and Agriculture Organization of the United Nations

Rome, 2021 



\section{Contents}

Authors

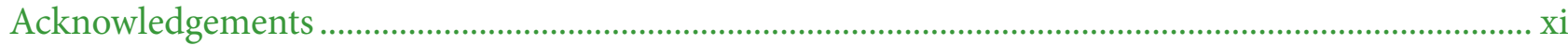

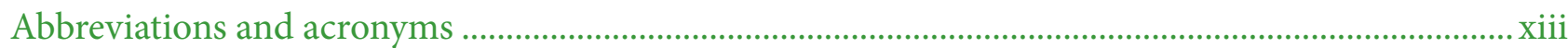

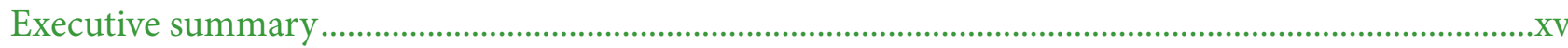

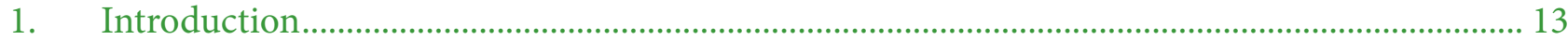

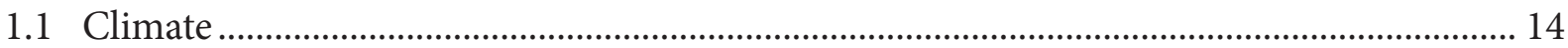

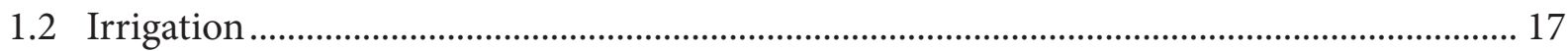

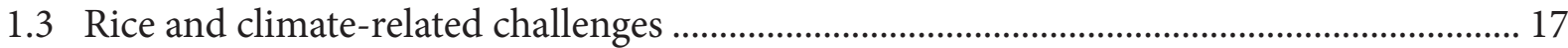

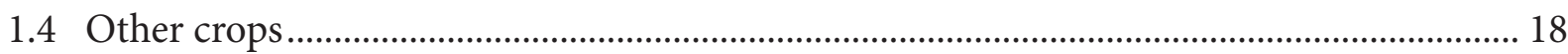

2. Assessing climate impacts on crop yields in Sri Lanka:methodology......................................... 19

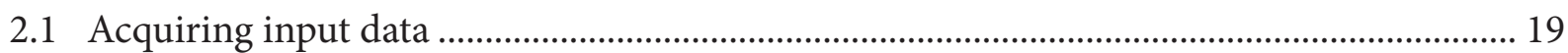

2.2 Selecting the most relevant crops and districts....................................................................... 21

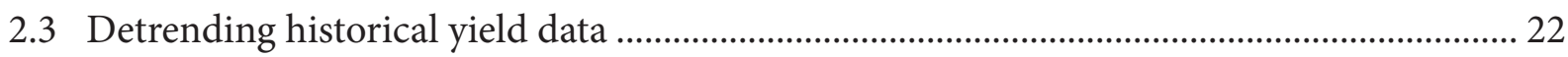

2.4 Modelling soil water balance ................................................................................................ 24

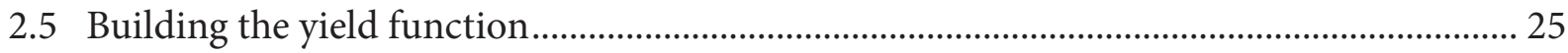

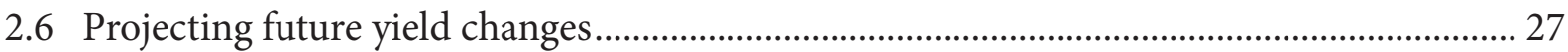

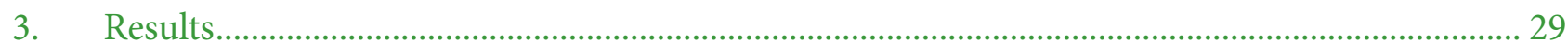

3.1 Cultivated area and yield trends at the national level ..........................................................29

3.2 Cultivated area, yield trend and anomaly at the district level............................................. 33

3.3 Regression models (yield functions) ...................................................................................... 35

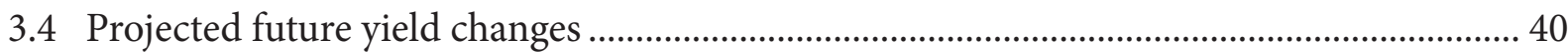

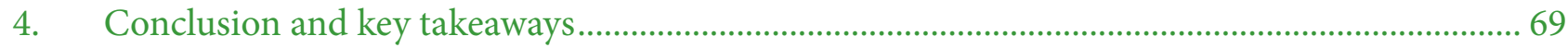

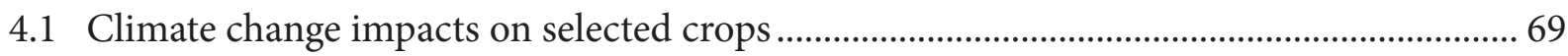

4.2 Extended benefits of the MOSAICC approach......................................................................... 72

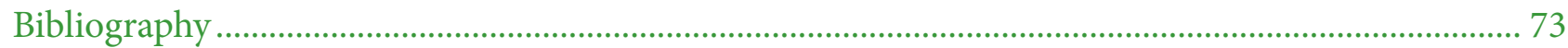

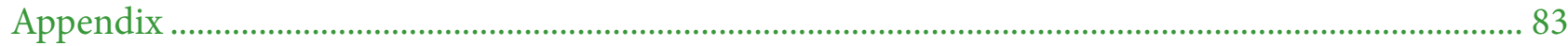




\section{Figures}

1 Agro-ecological regions of Sri Lanka .........................................................................................

2 Annual rainfall in Sri Lanka ................................................................................................

3 Sri Lanka districts per climatic zone ……………………………………………………... 11

4 Generalized crop coefficient curve forthe single crop coefficient approach ............................... 13

$5 \quad$ National cultivated area for Maha season................................................................................... 17

$6 \quad$ National cultivated area for the Yala season ............................................................................ 18

$7 \quad$ Average national yields for the Maha season ............................................................................. 19

$8 \quad$ Average national yields for the Yala season .............................................................................. 20

9 Projected changes in selected climate and water balance parameters averaged overthe Maha growing season, according to the CanESM2 model ................................ 30

10 Projected rice yield changes for the Maha season, rainfed regime,according to MPI-ESM-MR and CanESM2 climate models............................... 32

11 Projected rice yield changes for the Maha season, rainfed regime, accordingto CNRM-CM5 and GFDL-ESM2M models ......................................33

12 Projected rice yield changes for the Maha season, rainfed regime,according to IPSL-CM5A-MR and MIROC-ESM models ................................... 33

13 Projected rice yield changes for the Maha season, irrigated regime,according to MPI-ESM-MR and CanESM2 climate models ........................... 34

14 Projected rice yield changes for the Maha season, irrigated regime,according to CNRM-CM5 and GFDL-ESM2M models

15 Projected rice yield changes for the Maha season, irrigated regime,according to IPSL-CM5A-MR and MIROC-ESM models.................................. 35

16 Projected rice yield changes for the Yala season, irrigated regime,according to MPI-ESM-MR and CanESM2 climate models ............................. 36

17 Projected rice yield changes for the Yala season, irrigated regime,according to CNRM-CM5 and GFDL-ESM2M models.

18 Projected rice yield changes for the Yala season, irrigated regime,according to IPSL-CM5A-MR and MIROC-ESM models.................................. 37

19 Projected maize yield changes for the Maha season, irrigated regime,according to MPI-ESM-MR and CanESM2 climate models

20 Projected maize yield changes for the Maha season, irrigated regime,according to CNRM-CM5 and GFDL-ESM2M models

21 Projected maize yield changes for the Maha season, irrigated regime,according to IPSL-CM5A-MR and MIROC-ESM models.................................. 39

22 Projected maize yield changes for the Yala season, irrigated regime,according to MPI-ESM-MR and CanESM2 climate models ............................. 40

23 Projected maize yield changes for the Yala season, irrigated regime,according to CNRM-CM5 and GFDL-ESM2M models.

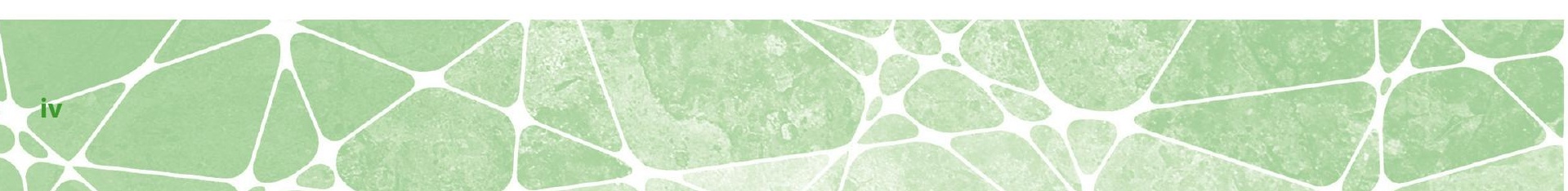


24 Projected maize yield changes for the Yala season,

irrigated regime,according to IPSL-CM5A-MR and MIROC-ESM models................................ 41

25 Projected big onion yield changes for the Yala season,

irrigated regime,according to MPI-ESM-MR and CanESM2 climate models ........................... 42

26 Projected big onion yield changes for the Yala season,

irrigated regime,according to CNRM-CM5 and GFDL-ESM2M models

27 Projected big onion yield changes for the Yala season,

irrigated regime,according to IPSL-CM5A-MR and MIROC-ESM models

28 Projected green gram yield changes for the Maha season,

irrigated regime, according to MPI-ESM-MR and CanESM2 climate models

29 Projected green gram yield changes for the Maha season,

irrigated regime, according to CNRM-CM5 and GFDL-ESM2M models

30 Projected green gram yield changes for the Maha season,

irrigated regime, according to IPSL-CM5A-MR and MIROC-ESM models.

31 Projected green gram yield changes for the Yala season,

irrigated regime,according to MPI-ESM-MR and CanESM2 climate models

32 Projected green gram yield changes for the Yala season,

irrigated regime, according to CNRM-CM5 and GFDL-ESM2M models.

33 Projected green gram yield changes for the Yala season,

irrigated regime,according to IPSL-CM5A-MR and MIROC-ESM models

34 Projected potato yield changes for the Maha season,

irrigated regime, according to MPI-ESM-MR and CanESM2 climate models

35 Projected potato yield changes for the Maha season,

irrigated regime, according to CNRM-CM5 and GFDL-ESM2M models

36 Projected potato yield changes for the Maha season,

irrigated regime,according to IPSL-CM5A-MR and MIROC-ESM models.

37 Projected potato yield changes for the Yala season,

irrigated regime, according to MPI-ESM-MR and CanESM2 climate models

38 Projected potato yield changes for the Yala season,

irrigated regime,according to CNRM-CM5 and GFDL-ESM2M models

39 Projected potato yield changes for the Yala season,

irrigated regime, according to IPSL-CM5A-MR and MIROC-ESM models

40 Projected chilli yield changes for the Maha season,

irrigated regime, according to MPI-ESM-MR and CanESM2 climate models

41 Projected chilli yield changes for the Maha season,

irrigated regime, according to CNRM-CM5 and GFDL-ESM2M models

42 Projected chilli yield changes for the Maha season,

irrigated regime,according to IPSL-CM5A-MR and MIROC-ESM models.

43 Projected chilli yield changes for the Yala season, irrigated regime,according to MPI-ESM-MR and CanESM2 climate models 
44 Projected chilli yield changes for the Yala season,

irrigated regime,according to CNRM-CM5 and GFDL-ESM2M models.................................... 55

45 Projected chilli yield changes for the Yala season,

irrigated regime, according to IPSL-CM5A-MR and MIROC-ESM models................................ 55

A1 Rice cultivatd extent - Maha season - Rainfed.......................................................................... 71

A2 Rice cultivated area - Maha season - Irrigated......................................................................... 72

A3 Rice cultivated area- Yala season - irrigated.......................................................................... 73

A4 Rice yield and trend line - Maha season - Rainfed................................................................... 74

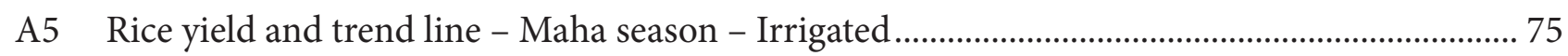

A6 Rice yield and trend line - Yala season - Irrigated................................................................. 76

A7 Rice yield anomaly - Maha season - Rainfed ........................................................................ 77

A8 Rice yield anomaly - Maha season - Irrigated ...................................................................... 78

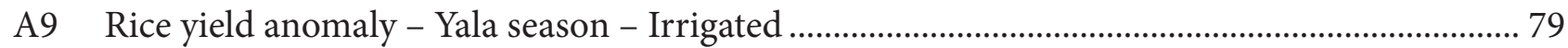

A10 Maize cultivated area - Maha season - Irrigated.................................................................... 80

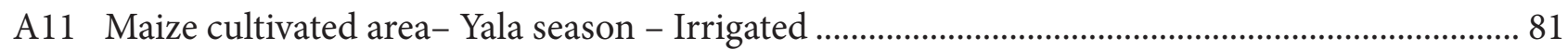

A12 Maize yield and trend line - Maha season - Irrigated ............................................................ 82

A13 Maize yield and trend line - Yala season - Irrigated.................................................................... 83

A14 Maize yield anomaly - Maha season - Irrigated ................................................................. 84

A15 Maize yield anomaly - Yala season - Irrigated ……….................................................................. 85

A16 Big onion cultivated area - Yala season - Irrigated................................................................. 85

A17 Big onion yield and trend line - Yala season - Irrigated ......................................................... 86

A18 Big onion yield anomaly - Yala season - irrigated ........................................................................ 86

A19 Green gram cultivated area - Maha season - Irrigated ............................................................... 87

A20 Green gram cultivated area - Yala season - irrigated ............................................................. 87

A21 Green gram yield and trend line - Maha season - Irrigated......................................................... 88

A22 Green gram yield and trend line - Yala season - Irrigated .................................................... 88

A23 Green gram yield anomaly - Maha season - Irrigated ............................................................. 89

A24 Green gram yield anomaly - Yala season - Irrigated ....................................................................... 89

A25 Potato cultivated area - Maha season - Irrigated .................................................................. 90

A26 Potato cultivated area - Yala season - Irrigated.......................................................................... 90

A27 Potato yield and trend line - Maha season - Irrigated ............................................................ 90

A28 Potato yield and trend line - Yala season - Irrigated …........................................................... 91

A29 Potato yield anomaly - Maha season - Irrigated............................................................................. 91

A30 Potato yield anomaly - Yala season - Irrigated...................................................................... 91

A31 Chilli cultivated area - Maha season - Irrigated ...................................................................... 92

A32 Chilli cultivated area - Yala season - Irrigated ...................................................................... 93

A33 Chilli yield and trend line - Maha season - Irrigated..................................................................... 94

A34 Chilli yield and trend line - Yala season - Irrigated .................................................................. 95

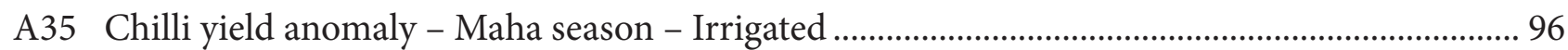

A36 Chilli yield anomaly - Yala season - Irrigated .................................................................................... 97 


\section{Tables}

1. Rainfall seasons in Sri Lanka 2

2. Approximate start, length and end of cropping seasons...............................................................

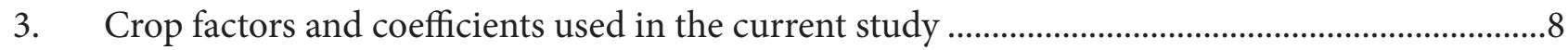

4. Relevant districts for the six selected crops in the Maha and Yala seasons................................ 10

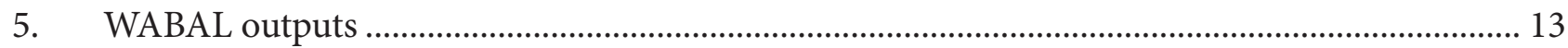

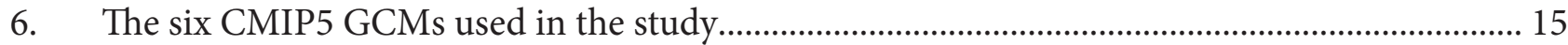

7. Yield functions for rice per season, irrigation regime and district............................................... 25

8. Yield functions for maize per season and district.................................................................. 26

9. Yield functions for big onion per season and district ............................................................... 26

10. Yield functions for green gram per season and district ............................................................ 27

11. Yield functions for potato per season and district....................................................................... 27

12. Yield functions for chilli per season and district ...................................................................... 28 


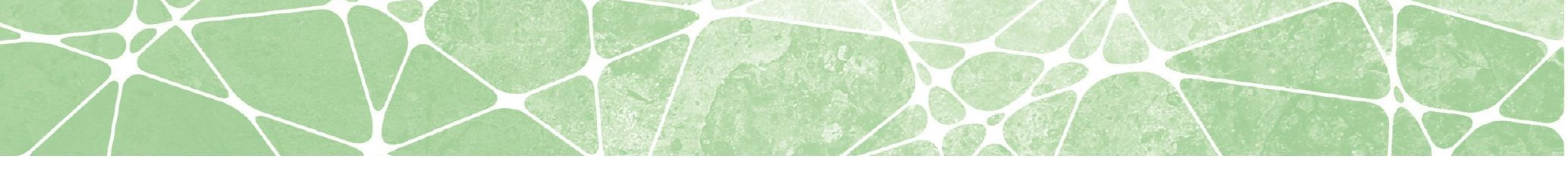




\section{Authors}

Ruwanga Amarasingha

Buddhi Marambe

Lalith Suriyagoda

Ranjith Punyawardena

Rasanayake Herath

Shiromani Jayawardena

Preethika Jayakody

Maria Raffaella Vuolo

Mariko Fujisawa

Ana Heureux

Jorge Alvar-Beltrán

Rodrigo Manzanas

Marco Acutis

Olivier Crespo

Hideki Kanamaru

Sandra Corsi
(Faculty of Agriculture, University of Peradeniya, Sri Lanka)

(Faculty of Agriculture, University of Peradeniya, Sri Lanka)

(Faculty of Agriculture, University of Peradeniya, Sri Lanka)

(Natural Resources Management Centre, Department of

Agriculture, Sri Lanka)

(Socio Economics and Planning Centre, Department of Agriculture, Sri Lanka)

(Department of Meteorology, Sri Lanka)

(Department of Meteorology, Sri Lanka)

(Food and Agriculture Organization of the United Nations

[FAO], Rome)

(FAO, Rome)

(FAO, Rome)

(FAO, Rome)

(Department of Applied Mathematics and Computer Science, University of Cantabria, Spain)

(University of Milan, Italy)

(University of Cape Town, South Africa)

(FAO, Regional Office for Asia and the Pacific, Bangkok)

(FAO, Rome) 


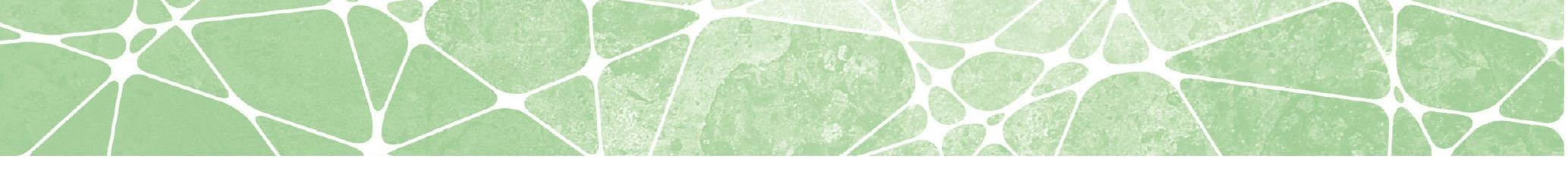




\section{Acknowledgements}

This publication was produced as a collaboration between FAO, the Department of Agriculture of Sri Lanka, the Department of Meteorology of Sri Lanka, the University of Peradeniya in Sri Lanka, the University of Cantabria in Spain and the University of Milan in Italy.

The authors wish to express their gratitude to Jingyuan Xia (Director, Plant Production and Protection), Rémi Nono Womdim (Deputy Director, Plant Production and Protection), Fenton Beed (Team Leader, Rural and Urban Crop and Mechanization Systems), Lev Neretin (Team Leader for Safeguards, Climate Risk and Bioeconomy), Josef Kienzle (Agricultural Engineer, FAO) for their invaluable support in the implementation of the German-funded FAO project "Building the basis for implementing the Save and Grow approach - Regional strategies on sustainable and climate-resilient intensification of crop systems" that led to the development of this publication.

The editing was undertaken by Ruth Duffy, and the layout was designed and implemented by Timour Madibaev. 


\section{Abbreviations and acronyms}

$\begin{array}{ll}\text { AER } & \text { Agro-ecological region } \\ \text { AIC } & \text { Akaike information criterion } \\ \text { DoA } & \text { Department of Agriculture } \\ \text { DZ } & \text { Dry zone } \\ \text { ETa } & \text { Actual evapotranspiration } \\ \text { ETc } & \text { Crop evapotranspiration } \\ \text { ETo } & \text { Reference evapotranspiration } \\ \text { EXC } & \text { Water excess } \\ \text { FAO } & \text { Food and Agriculture Organization of the United Nations } \\ \text { FIM } & \text { First inter-monsoon } \\ \text { GDP } & \text { Gross domestic product } \\ \text { GCM } & \text { General circulation model } \\ \text { IZ } & \text { Intermediate zone } \\ \text { Kc } & \text { Crop coefficient } \\ \text { MOSAICC } & \text { Modelling System for Agricultural Impacts of Climate Change } \\ \text { NEM } & \text { Northeast monsoon } \\ \text { RCP } & \text { Representative concentration pathway } \\ \text { SIM } & \text { Second inter-monsoon } \\ \text { SWM } & \text { Southwest monsoon } \\ \text { Wa } & \text { Available water } \\ \text { WHC } & \text { Water holding capacity } \\ \text { WZ } & \text { Wet zone }\end{array}$




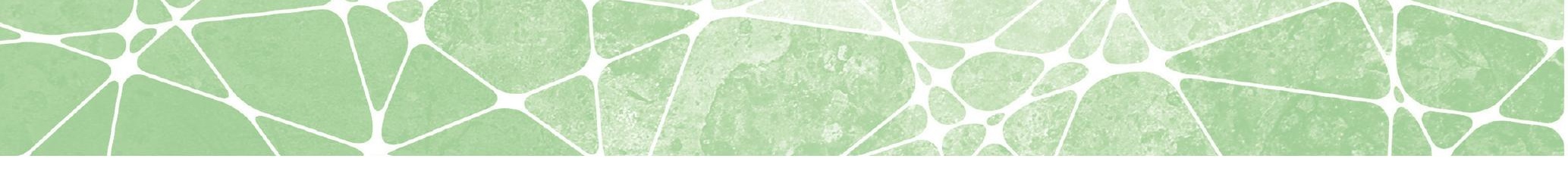




\section{Executive summary}

Agriculture is one of the most important economic sectors of Sri Lanka and is key to the livelihood of its population. As agriculture is one of the sectors most vulnerable to climate change, a thorough understanding of its impact is critical for formulating informed and effective adaptation strategies.

Climate change challenges agriculture in many ways and affects - directly or indirectly - the economy, productivity, employment and food security. Assessing the impacts of climate change on crops is fundamental for elaborating evidence-based adaptation policies and strategies, guaranteeing sustainable pathways towards intensification and adopting climate-smart agricultural practices.

This report presents insights about future climate change impacts on six crops (rice, maize, green gram, big onion, chilli and potato), selected according to a wide range of criteria: contribution to gross domestic product, relevance to food security and role as staple food, importance for farming systems, social impact, effect on employment, role as animal feed, consumer preferences, contribution to the export market, climatic vulnerability/resilience, market prices and price fluctuations, and farming input requirements. Future climate change impacts on these crops were evaluated using the Modelling System for Agricultural Impacts of Climate Change (MOSAICC) of the Food and Agriculture Organization of the United Nations (FAO) (FAO, 2020a). The assessment was carried out for the two major agricultural growing seasons of Sri Lanka, namely "Maha" (October-February) and "Yala" (March-September). For all six crops, irrigated cultivation in both seasons (Maha and Yala) was considered; for rice, a third regime - rainfed cultivation in the Maha season - was also taken into account. The districts for the cultivation of the selected crops are located in the three major climatic zones of the country: wet zone (WZ), intermediate zone (IZ) and dry zone (DZ). The yield functions were constructed per crop, district and season, using the observed yield responses to past climate and simulated water balance conditions. The projected future changes for the six crops were calculated as the yield difference between future and historical yields for each combination of climate data modelled with six general circulation models (GCMs), two representative concentration pathways (RCP4.5 and RCP8.5) and two future periods (middle and far future, until 2100).

The response to climate change of the six selected crops is highly variable depending on the season and climatic zone.

For Yala rice production under the irrigated regime, future projected yield change is positive in wet, intermediate and dry zones, while for Maha rice production, both rainfed and irrigated regimes present negative impacts, especially in the lowlands (Anuradhapura district). As the negative impact may be due to floods, policies oriented towards adaptation to floods and mitigation of their effects for those districts could be advantageous in terms of food security in Sri Lanka. 
For maize, negative yield changes are projected in the Maha season in both the dry and the intermediate zone, while both negative and positive yield changes are projected in the Yala season.

The projected yield of green gram is negative throughout Sri Lanka, irrespective of the season, with yield functions suggesting this crop is particularly sensitive to temperature increase. Therefore, adoption of varieties resistant to high temperatures could be a beneficial adaptation measure for green gram.

Climate change impact on big onion is projected to be positive in the Yala season. However, this result needs to be validated with more data and modelling, as there is no national reference about big onion projections with climate change. If the results are confirmed, big onion could be a promising crop in a context of rising temperatures.

Potato yields are projected to be negative in Nuwara Eliya district, in both Yala and Maha seasons, but positive in Jaffna district during the Maha season, probably due to the positive effect of the projected rainfall increase in the dry zone. This result warrants further investigation and points towards the potential appeal of cultivating potato in the dry zone in the future.

The results of this study are conditioned by a range of uncertainties, as acknowledged in the methodology section, but they are generally consistent with previous studies and represent a highquality source of information for formulating adaptation strategies. These strategies should be oriented in part to promote and fund similar research studies to gain a deeper understanding of the conclusions drawn from MOSAICC. This is particularly important for crops and zones for which there are no - or only limited - past studies to assess the potential impacts of climate change (i.e. big onion, chilli, potato). In-depth investigations should be promoted through long-term research projects and programmes, with the generation, collection and analysis of high-quality data on agriculture and climate.

The MOSAICC process should be further promoted in new projects and programmes, as the modelling system and platform is now at the disposal of the country's institutions (hosted by the Department of Agriculture, Sri Lanka). The modelling exercise can be carried out at any given time by national experts - as new data become available, when interest in new crops emerge, or if other modelling options of MOSAICC (e.g. modelling impacts on hydrology and economy) become desirable. The MOSAICC methodology is indeed flexible and presents great potential for improving and enriching results by refining the modelling/analysis choices, and integrating new data sets and information into the MOSAICC database.

The activities were carried out in the framework of the project "Building the basis for implementing the Save and Grow approach - regional strategies on sustainable and climate-resilient intensification of cropping systems" (FAO, 2021), funded by the Government of Germany, with the involvement of FAO in Sri Lanka and four country institutions, both academic and governmental: the Faculty of 
Agriculture of the University of Peradeniya, the Department of Meteorology, the Natural Resources Management Centre of the Department of Agriculture (DoA), and the Socio Economics and Planning Centre of the DoA.

In addition to the scientific results that have provided high-quality, evidence-based support for informed policy formulation, the project and the MOSAICC approach have strengthened interinstitutional collaboration and created a cooperative working framework among national and international institutions. This achievement goes beyond the results of the modelling exercise itself, creating the basis for a sustainable, evidence-based and multidisciplinary path for the formulation of climate change adaptation strategies. 


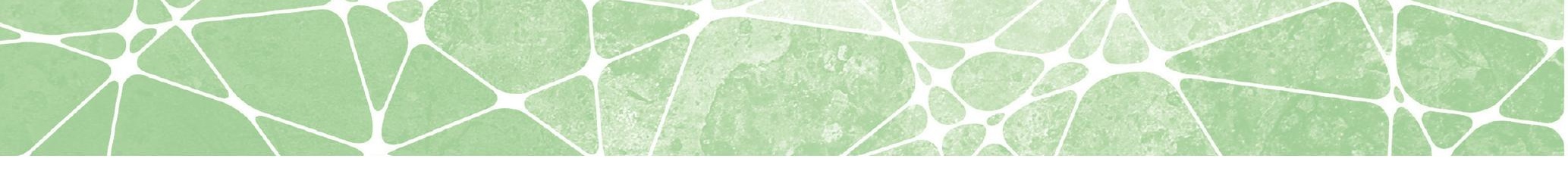




\section{Introduction}

Sri Lanka is an island located in the Indian Ocean between $5^{\circ} 55^{\prime}-9^{\circ} 50^{\prime}$ north latitude and $79^{\circ} 42^{\prime}-$ $81^{\circ} 53^{\prime}$ east longitude.

Agriculture is one of the most important sectors of the economy of Sri Lanka and is key to the livelihood of its population. In 2019, the contribution of the agriculture sector to the gross domestic product (GDP) was about 7 percent - a growth rate of 6.5 percent compared to 2018. Moreover, 72 percent of the population are indirectly involved in agriculture-related activities for their livelihood (Gunasena, 2008), and the sector provided direct employment to about 25.3 percent of the total workforce in 2018 (CBSL, 2018).

In this context, it is crucial to consider the future impacts of climate change on the country's agriculture, economy, employment and food security in order to support informed adaptation planning and policies. This report presents insights about future impacts of climate change on six selected crops, based on the country's climate and agriculture observed data and the use of the Modelling System for Agricultural Impacts of Climate Change (MOSAICC) of the Food and Agriculture Organization of the United Nations (FAO).

The MOSAICC approach combines the advantages of statistical models for ease of use over large areas and a relatively wide range of agroecological conditions, as it does not need the extensive input data (e.g. cultivars, management and soil conditions) and in situ calibration required by process-based models, while there is the option of taking into account some of the crop-specific responses to the environmental conditions (as with process-based models) the approach is particularly suitable when long historical time series of both climate and yields are available. It has successfully been applied in several countries at the national and subnational levels, such as regional, provincial and agro-ecological zone. See FAO (2020b, 2020c, 2020d) and Balaghi et al. (2016) for MOSAICC applications in Paraguay, Uruguay and Morocco.

MOSAICC is a multi-model, multi-user approach for climate change assessment on crops, hydrology, forestry and economy (in this work, only climate and crop components were used). The system builds on multi-user technology and a common database, and the users are typically experts in their respective fields, from various institutions in the country (both governmental and academic). The approach is highly participatory, country driven and multidisciplinary. Interinstitutional exchanges and collaboration are fostered throughout the process, from data collection to formulation of policy recommendations. The activities were carried out in the framework of the project "Building the basis for implementing the Save and Grow approach - regional strategies on sustainable and climate-resilient intensification of cropping systems" (FAO, 2021), funded by the Government of Germany, with the involvement of FAO in Sri Lanka and four country institutions, both academic and governmental: the Faculty of Agriculture of the University of Peradeniya, 
the Department of Meteorology, the Natural Resources Management Centre of the Department of Agriculture (DoA), and the Socio Economics and Planning Centre of the DoA.

\subsection{Climate}

The climates of Sri Lanka belong to the Aw, Am, Af and Cfb Köppen-Geiger climatic zones. The country is divided into 46 agro-ecological regions (AERs) (Figure 1) spread over three major climatic zones: wet zone (WZ), intermediate zone (IZ) and dry zone (DZ). The AERs are characterized by unique climate, soil and terrain conditions, and each AER exhibits different attributes in terms of natural vegetation. The optimal conditions of a specific land-use and farming system vary significantly depending on the AER (Punyawardena et al., 2003).

Detailed studies on the climatology of Sri Lanka have identified the start of the "climatic year" or "hydrological year" as March; the seasonal weather cycle punctuated by the rainfall seasons lasts until February the following year (Punyawardena, Dissanayake and Mallawathanthri, 2013). It is generally accepted that there are four rainfall seasons in Sri Lanka (Table 1 and Figure 2).

Rainfall is heterogeneous across the island, resulting in high agro-ecological diversity despite the relatively small aerial extent. Of the four rainfall seasons, two consecutive rainy seasons comprise the major agricultural growing seasons of Sri Lanka, namely "Yala" and "Maha". Generally, the Yala season is the combination of the first inter-monsoon (FIM) and southwest monsoon (SWM) rains. However, since the SWM rains do not fall in the dry zone, the DZ Yala season only benefits from the FIM rains from mid-March to early May. The major agricultural growing season nationwide, Maha, begins with arrival of the second inter-monsoon (SIM) rains in mid-September/October and continues until late January/February with the northeast monsoon (NEM) rains (Punyawardena, Dissanayake and Mallawathanthri, 2013).

The main factor influencing the geographical distribution of rainfall is the orographic nature of the island. The central part of Sri Lanka is characterized by the Central Highlands - a series of well-defined high plains and plateaus rimmed by high mountain peaks and ridges reaching elevations of 910-2 $524 \mathrm{~m}$ (Chandrajith, 2020). Almost all river networks in Sri Lanka originate from the highlands and radiate to the Indian Ocean. According to the direction of the monsoon, the Central Highlands act as a climatic divide, presenting a windward and a

Table 1. Rainfall seasons in Sri Lanka

\begin{tabular}{|l|l|}
\hline \multicolumn{1}{|c|}{ Months } & \multicolumn{1}{c|}{ Rainfall } \\
\hline March-April & First inter-monsoon (FIM) \\
\hline May-September & Southwest monsoon (SWM) \\
\hline October-November & Second inter-monsoon (SIM) \\
\hline December-February & Northeast monsoon (NEM) \\
\hline
\end{tabular}

Source: DoA, 2018. leeward side. During each monsoon season, the moisture-laden air is orographically lifted along the windward slopes producing heavy rain exceeding $4000 \mathrm{~mm}$ annually. However, on the leeward side, which forms a rain shadow within the highlands, the monsoon wing is warm and dry bringing around $2000 \mathrm{~mm}$ of rain a year. 


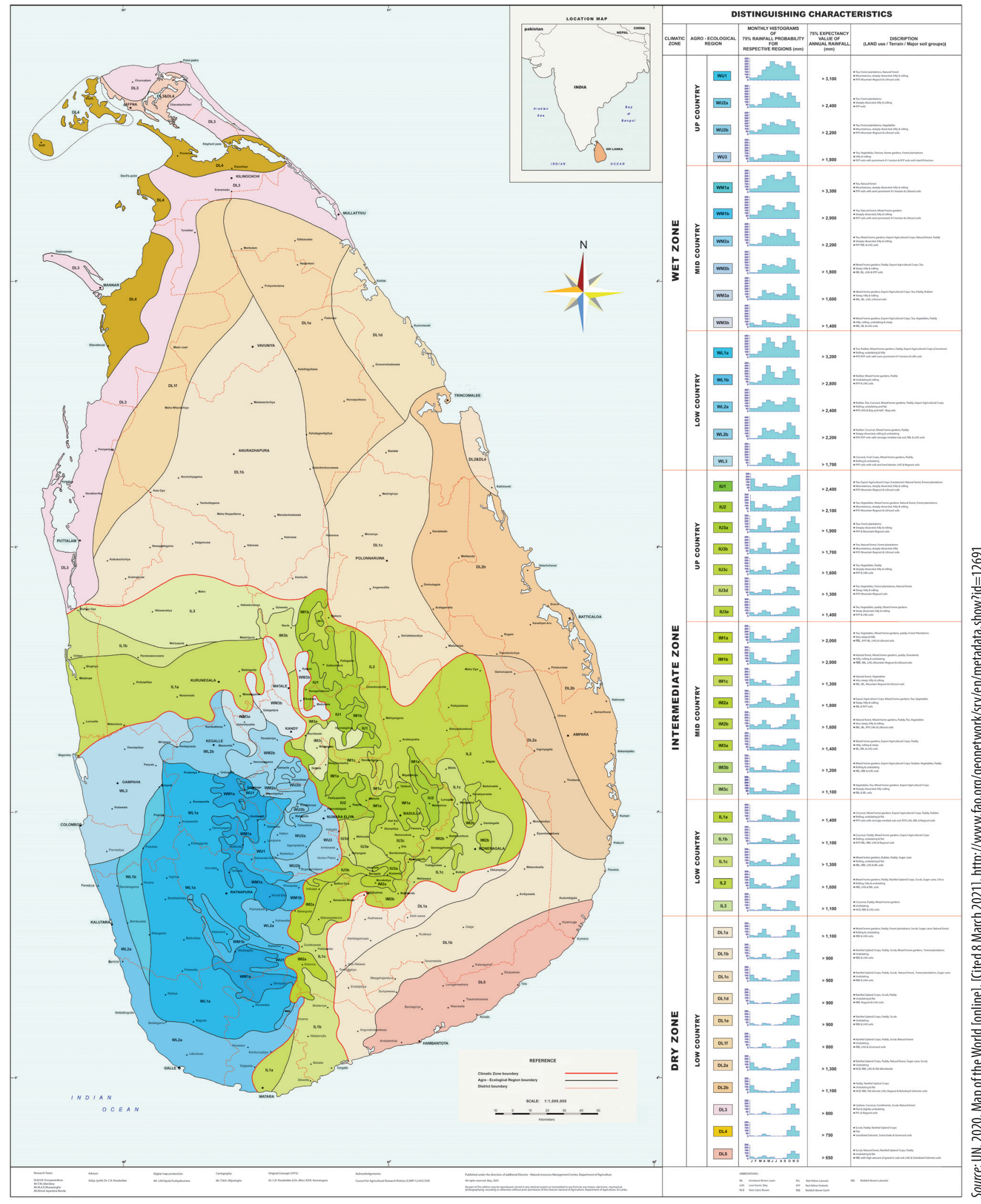

Figure 1. Agro-ecological regions of Sri Lanka 


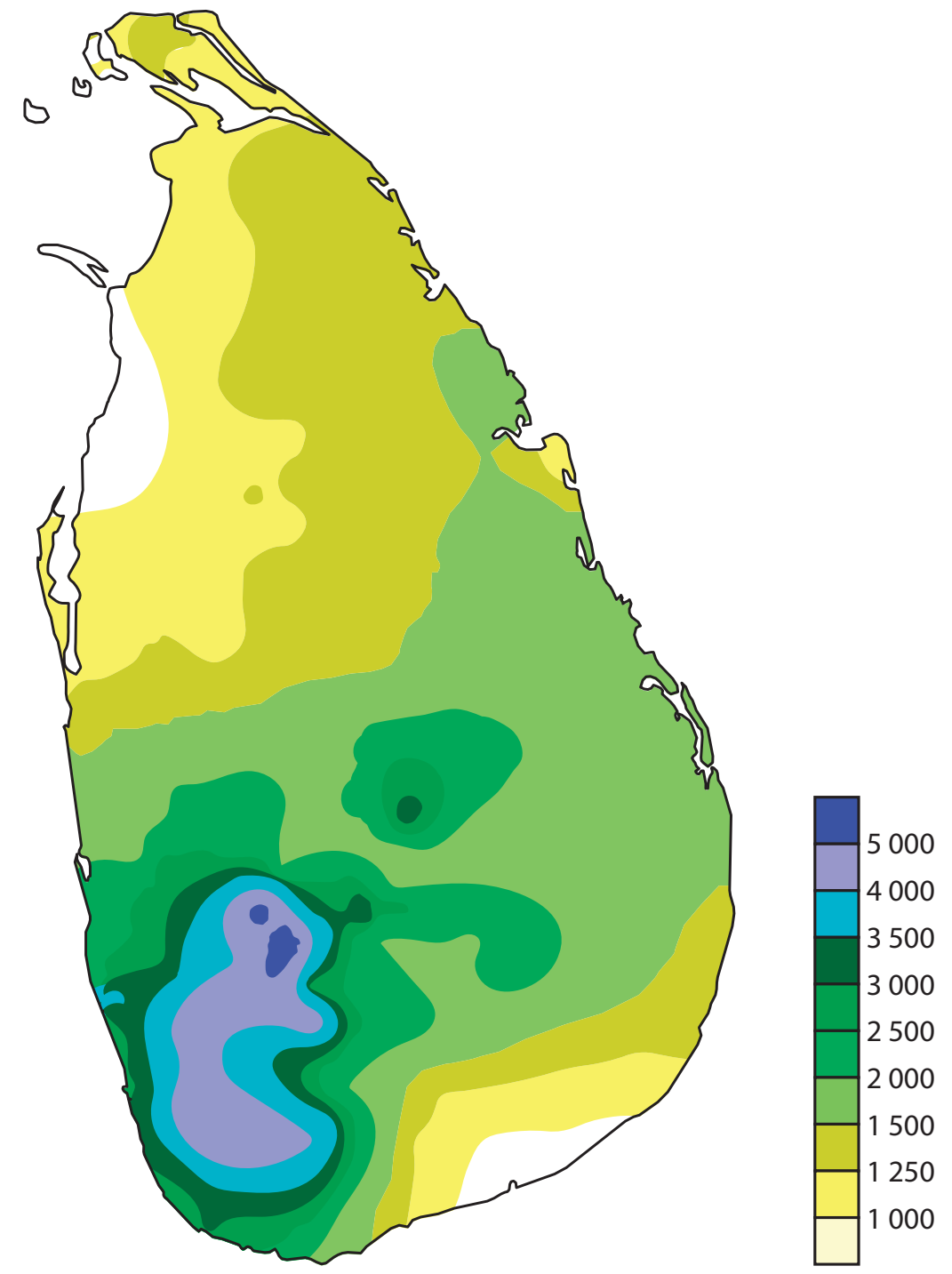

Season Rainfall
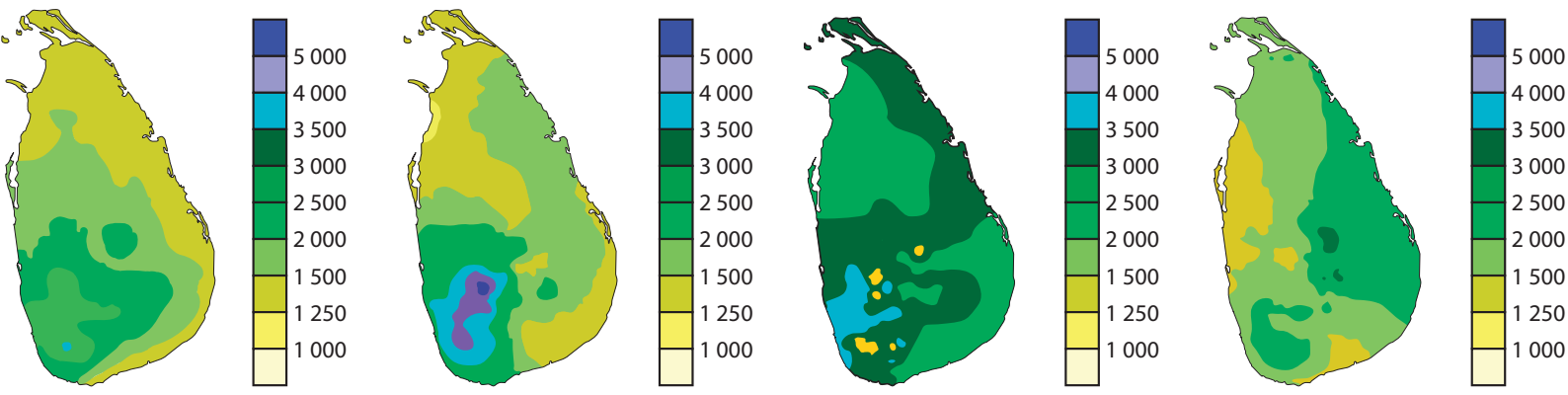

IMI (Mar-Apr)

SWM (May-Sep)

IM2 (Oct-Nov)

NEM (Dec-Feb) 


\subsection{Irrigation}

Irrigation schemes in Sri Lanka are divided into major and minor based on the command area. Major irrigation schemes have a command area of $>80$ ha, and minor irrigation schemes systems $<80$ ha. Paddy is grown under both major and minor irrigation schemes in the Yala season and also under rainfed conditions during the Maha season (with the water supply coming only from incidental rainfall and phreatic water). Seventy percent of the lowlands in the dry zone are cultivated with rice during the Maha season, compared with around 50 percent in the Yala season due to water scarcity. Apart from rice, other field crops such as maize, green gram, soybean and vegetables are also grown annually, particularly when there is insufficient water for rice cultivation.

\subsection{Rice and climate-related challenges}

Rice, as the staple food in the country, accounts for about 37 percent of per capita calories and 30 percent of per capita protein in the average diet (Department of Census and Statistics, 2019). Paddy cultivation in Sri Lanka is strongly influenced by landscape and climate, leading to considerable variation across the country. Most of the paddy cultivation in the dry and intermediate zones is irrigated, while a significant area is rainfed during the Maha season in the intermediate zone.

The impacts of climate change on rice have been studied extensively compared to other crops, especially with regard to crop development and growth. The suitable temperature range for the vegetative growth of rice is $12-35^{\circ} \mathrm{C}$ with optimum temperature around $25-30^{\circ} \mathrm{C}$ (Yoshida, 1978). The most dangerous effect of increasing temperature is rice grain sterility. A very brief high temperature event (1-2 hours) at anthesis (flowering) can result in a large number of sterile pollen grains. Rice grain sterility increases when the spikelet temperature rises above $30{ }^{\circ} \mathrm{C}$ and complete sterility is reached at $36^{\circ} \mathrm{C}$, especially under high relative humidity (Abeysiriwardena, Ohba and Maruyama, 2002; Weerakoon, Maruyama and Ohba, 2008).

Thus, even though increasing atmospheric $\mathrm{CO}_{2}$ concentration can have a positive impact on yields, both real-scale agronomical limitation and the negative effects of high temperature may result in lower rice yields (De Costa, 2000; Delpitiya et al., 2014). Indeed, Delpitiya et al. (2014) estimated that a temperature increase of $2{ }^{\circ} \mathrm{C}$ (both maximum and minimum temperature) would result in a rice yield reduction of 12 percent. Moreover, a study conducted in one of the major rice-growing districts of Sri Lanka (Kurunegala) predicted a reduction in grain yield of 20 percent under the RCP8.5 climate scenario (the worst case) by the middle of the century (Weerakoon, 2013).

Rice, a crop grown in standing water for most of its life cycle, usually requires 1 500-2 $000 \mathrm{~mm}$ of water per season for establishment, growth and weed control (Bouman, 2001). Variability in precipitation quantity and distribution, as well as in the onset of the rainy season, limits the yield of rainfed rice and leads to variation in farming operations. Punyawardena (2002) defines the onset of a 
rainy season as the first of the three consecutive weeks where there is a spell of at least $30 \mathrm{~mm}$ of rain per week after a pre-specified week of the year (i.e. for the Maha season standard week 35, and for the Yala season standard week 9).

Irrigated rice systems may also be affected if rainfall is low or delayed in the catchments of the respective reservoirs. As noted by Nguyen (2002), flood is the most important constraint to rice production in low-lying areas of Sri Lanka's Eastern and Western Provinces. In recent years, increasing weather extremes such as heavy rainfall and prolonged dry conditions have caused severe damage to rice production (Marambe et al., 2015). Rice grown near coastal regions will be more affected by increasing salinity in paddies due to saline water intrusion associated with sea level rise (De Costa, 2010).

\subsection{Other crops}

In addition to rice, most other crops such as coarse grains, legumes, fruits, vegetables and tuber crops are also adversely affected by the impacts of climate change (Titumil and Basak, 2010). Yield reductions are evident for maize (Amarasingha et al., 2018; Malaviarachchi et al., 2015) and green gram (Malaviarachchi et al., 2015, 2016) with increasing temperatures during the growing season; on the other hand, chilli yield responds positively to increasing temperatures (Abhayapala et al., 2018). Droughts and floods significantly impact fruit and vegetable production mainly in the dry zone. Increasing temperature will increase evapotranspiration rates and losses, resulting in greater soil moisture deficits and temporal evolution of soil salinity in upland cropping systems. Moreover, rising ambient temperatures could increase the field heat and respiration rates of perishable horticultural products, thereby increasing post-harvest losses and storage costs. In recent decades, the increase in minimum or night-time temperatures has been more significant than the increase in maximum temperature, with a consequent reduction in night-day thermal amplitude (Marambe et al., 2015). This has negatively affected the yield of tuber crops (e.g. potato) as assimilation and tuber bulking narrow down. 


\section{Assessing climate impacts on crop yields in Sri Lanka: methodology}

The MOSAICC methodology for assessing impacts of climate change on crops is based on a six-step process:

1. Acquiring input data (subsection 2.1).

2. Selecting the most relevant crops and districts (subsection 2.2), based mainly on expert judgement according to both quantitative and qualitative criteria.

3. Detrending historical yield data (subsection 2.3). Widely used assumptions and statistical tools are adopted in order to remove most of the non-climatic components of the variation of the historical crop yields.

4. Modelling soil-crop water balance (subsection 2.4). Potential predictors are calculated for the statistical models built in the subsequent step (the yield function). This is achieved with the use of WABAL, the water balance model implemented in MOSAICC, with observed climate variables as input.

5. Building the yield function (subsection 2.5). Both water balance parameters (modelled as described in the previous subsection) and observed climate variables are used to build up a pool of potential predictors for the agricultural yields. The actual predictors are then selected by means of widely used statistical methods.

6. Projecting future yield changes (subsection 2.6). In the last step of the modelling chain, the water balance model and yield functions with modelled climate data are used to estimate future yield changes (difference between modelled future and modelled historical). These yield changes will be calculated separately for the different climate change scenarios, future periods (middle and far future), and districts, crops and irrigation modes.

\subsection{Acquiring input data}

The MOSAICC approach is based on a sequence of steps including both statistical and process-based modelling methods. The input data of the first modelling steps comprise observed climate data from weather stations, as well as crop data averaged at the spatial scale of interest. The output data of each modelling step constitute the input data of the subsequent steps, through to the final results (future projected yield changes).

\section{Climate data}

Daily precipitation, and maximum and minimum temperature data from more than 50 weather stations managed by the Sri Lanka Department of Meteorology were initially available. Following a rigorous quality control process, 33 stations were selected for climate downscaling and crop modelling tasks. The quality control procedure checked for outliers, continuity and consistency in the observed time series, as well as the percentage of missing data. In addition, the Sri Lanka 
Department of Meteorology and the University of Cantabria conducted a comprehensive comparison study between these 33 stations and the nearest grid box in the EWEMBI data set (Lange, 2016), which is increasingly used in climate-related impact studies. The 33 local weather stations were preferred for the climate change impact assessment performed here, as EWEMBI was found to exhibit critical biases at the local level (e.g. seasonal variability is not properly represented).

\section{Soil data}

The Harmonized World Soil Database (HWSD) was used for water-holding capacity of the soil (Fischer et al., 2008).

\section{Crop yield data}

The production, cultivated area and yield data for the six crops used in the study were provided by the Department of Agriculture. The selected crops were paddy, green gram, maize, big onion, chilli and potato, and the data were considered at the national and district levels, for the Maha and Yala seasons, and under different irrigation regimes.

\section{Crop calendars and phenology}

The analysis relies on the approximation of the start and end of the two main cropping seasons, Maha and Yala (Table 2). In the present study, these dates are considered fixed and eventual shifts

Table 2. Approximate start, length and end of cropping seasons

\begin{tabular}{|l|l|l|l|}
\hline & Start & Length & End \\
\hline Maha & 1 September & 17 dekads & 20 February \\
\hline Yala & 1 March & 17 dekads & 20 August \\
\hline
\end{tabular}

Source: National Agriculture Information and Communication Centre, Department of Agriculture, Sri Lanka. in the crop calendar under future climate conditions are not taken into account. For the crop factors and coefficients, the values used are from FAO Irrigation and Drainage Paper No. 56 (FAO, 1998) or from crop-specific literature for the country or similar climate regions where available. Crop factors and coefficients considered for this analysis are shown in Table 3.

Table 3. Crop factors and coefficients used in the current study

\begin{tabular}{|l|c|c|c|c|c|c|}
\hline \multicolumn{1}{|c|}{ Crop } & F1 & F2 & F3 & K1 & K2 & K3 \\
\hline Rice & 0.17 & 0.42 & 0.75 & 0.50 & 1.05 & 0.70 \\
\hline Maize & 0.09 & 0.46 & 0.84 & 0.30 & 1.20 & 0.35 \\
\hline Big onion & 0.29 & 0.54 & 0.92 & 0.70 & 1.50 & 0.75 \\
\hline Chilli & 0.25 & 0.46 & 0.79 & 0.30 & 0.95 & 0.85 \\
\hline Green gram & 0.13 & 0.47 & 0.73 & 0.40 & 1.05 & 0.35 \\
\hline Potato & 0.15 & 0.46 & 0.77 & 0.50 & 1.15 & 0.75 \\
\hline
\end{tabular}

Note: $F_{1}, F_{2}$ and $F_{3}$ represent the ratio between the period from the beginning of the growing cycle to the end of the growing stage "i" and the duration of the whole growing cycle. $\mathrm{K}_{1}, \mathrm{~K}_{2}$ and $\mathrm{K}_{3}$ are the crop coefficients at initial, mid and late development stages and measure the ratio between maximum crop evapotranspiration (ETc) and reference evapotranspiration (ETo). 


\subsection{Selecting the most relevant crops and districts}

Rice, maize, green gram, big onion, chilli and potato crops were selected for the study according to a wide range of criteria, including: contribution to GDP, relevance to food security and role as staple food, importance for farming systems, social impact, effect on employment, role as animal feed, consumer preferences, contribution to the export market, climatic vulnerability/resilience, market prices and price fluctuations, and farming input requirements (water, fertilizers). For all six crops, irrigated cultivation in both seasons (Maha and Yala) was considered; for rice, a third regime rainfed cultivation in the Maha season - was also taken into account.

Rice (Oryza sativa) is the staple food of the inhabitants of Sri Lanka, with an annual per capita consumption of about $107 \mathrm{~kg}$. Rice is the most important commercial crop in the country, with a total land area of 980000 ha (DoA, 2018). Rice is cultivated in both Maha and Yala seasons, across dry, intermediate and wet zones.

Maize (Zea mays) is the most important coarse grain cultivated in Sri Lanka, with demand for cultivation increasing among farmers in recent years. It is mainly cultivated in the Maha season under rainfed conditions in the highlands; in the Yala season, it is cultivated in both the highlands and the lowlands with supplementary irrigation.

Green gram (Vigna radiata) is an important pulse crop grown in Sri Lanka under traditional farming systems mainly in dry and intermediate zones. A component of the traditional diet of Sri Lanka, it has over the years provided both household income and employment opportunities to rural farmers.

Big onion (Allium cepa) is an important cash crop cultivated in Sri Lanka. In 2018, local annual production was 28057 tonnes from a cultivated area of 1448 ha (DoA, 2018), while the estimated annual demand in 2020 is approximately 290000 tonnes. It is mainly cultivated in dry and intermediate zones.

Chilli (Capsicum annuum) is one of the most important cash crops grown in Sri Lanka. It is an essential ingredient in meals. In 2018, per capita annual consumption of chilli in the form of dry chilli was around $2.43 \mathrm{~kg}$; the demand for dry chilli is around 57400 tonnes. Chilli contributes an average of LKR 500 million (USD 2.7 million) to GDP. The average cultivated area for chilli is approximately 13553 ha (DoA, 2018), two-thirds of which is cultivated in the Maha season. Chilli is cultivated on a large scale in dry and intermediate zones.

Potato (Solanum tuberosum) had a total national production of 88897 tonnes in 2018 and the cultivated area was 5174 ha. At present, potato is extensively cultivated in the highlands in the district of Nuwara Eliya in the upcountry wet zone during both the Maha and the Yala season. In Badulla, in the upcountry intermediate zone, potato cultivation during the Maha season is limited to the highlands (Kandu Kannaya), while during the Yala season cultivation shifts to the lowlands 
to replace paddy. Potato can be successfully grown in upcountry, wet, intermediate and dry zones at temperatures ranging from $24^{\circ} \mathrm{C}$ to $32^{\circ} \mathrm{C}$, as well as in Jaffna district during the Maha season when temperatures are cooler. The optimum day temperature is $20-25^{\circ} \mathrm{C}$ with a night/daytime temperature difference of $10^{\circ} \mathrm{C}$. The districts relevant for production of the six selected crops depend on the season; Table 4 shows the average cultivation area over the last 10 years, taking into account both the Maha and the Yala season. Of the selected districts, some are located in the dry zone, some in the intermediate zone and some in the wet zone (Figure 3).

Table 4. Relevant districts for the six selected crops in the Maha and Yala seasons

\begin{tabular}{|c|c|c|}
\hline \multirow[t]{2}{*}{ Crop } & \multicolumn{2}{|l|}{ Season } \\
\hline & Maha & Yala \\
\hline Rice $>10000$ ha & $\begin{array}{l}\text { Rainfed - Batticaloa, Kurunegala, Moneragala, Galle, Ampara, } \\
\text { Kilinochchi, Kalutara, Anuradhapura } \\
\text { Irrigated - Ampara, Polonnaruwa, Anuradhapura, Hambantota, } \\
\text { Batticaloa, Trincomalee, Kurunegala, Kilinochchi, Badulla, Mannar }\end{array}$ & $\begin{array}{l}\text { Ampara, Polonnaruwa, Batticaloa, Hambantota, } \\
\text { Anuradhapura, Trincomalee, Kurunegala }\end{array}$ \\
\hline Maize $>350$ ha & $\begin{array}{l}\text { Anuradhapura, Moneragala, Ampara, Badulla, Kurunegala, Matale, } \\
\text { Hambantota, Polonnaruwa, Trincomalee, Puttalam, Batticaloa }\end{array}$ & $\begin{array}{l}\text { Badulla, Anuradhapura, Moneragala, Kurunegala, } \\
\text { Polonnaruwa }\end{array}$ \\
\hline Green gram $>250$ ha & Moneragala, Hambantota, Kurunegala, Anuradhapura, Ampara, Puttalam & Moneragala, Hambantota, Kurunegala \\
\hline Big onion $>100$ ha & & Matale, Anuradhapura, Polonnaruwa, Kurunegala \\
\hline Potato $>50$ ha & Badulla, Nuwara Eliya, Jaffna & Badulla, Nuwara Eliya \\
\hline Chilli > 250 ha & $\begin{array}{l}\text { Anuradhapura, Moneragala, Puttalam, Hambantota, Kurunegala, Badulla, } \\
\text { Jaffna, Matale, Ampara, }\end{array}$ & $\begin{array}{l}\text { Puttalam, Kurunegala, Anuradhapura, Jaffna, } \\
\text { Hambantota, Badulla, Matale, Kandy }\end{array}$ \\
\hline
\end{tabular}

\subsection{Detrending historical yield data}

While observed yields depend on both climatic and non-climatic factors (e.g. improved technology, better management, changes in varieties, change in policy), the MOSAICC methodology only considers climatic factors.

Therefore, it is important to remove the effects of non-climatic factors from the observed yield data. It is assumed that short-term (annual) changes in yield vary mostly and most consistently in response to climatic factors, while observed long-term trends (on a time scale of the order of 20 years or more) incorporate non-climatic factors to a larger extent. This can be justified by the fact that non-climatic variables refer to the adoption of technologies that countries generally do not discontinue and therefore result in impacts on yields that have a smoother trend over time.

Thus, it is assumed that in the observed yields, the effects on trends due to non-climatic factors are greater than the effects of climate change, and that the effects of climate variables can be captured mostly by year-to-year variations.

Several studies outline the various detrending methodologies, their assumptions and potential impacts on the final modelling results (Kruse, 1999; Shi, Tao and Zhang, 2013; Ye et al., 2014). 


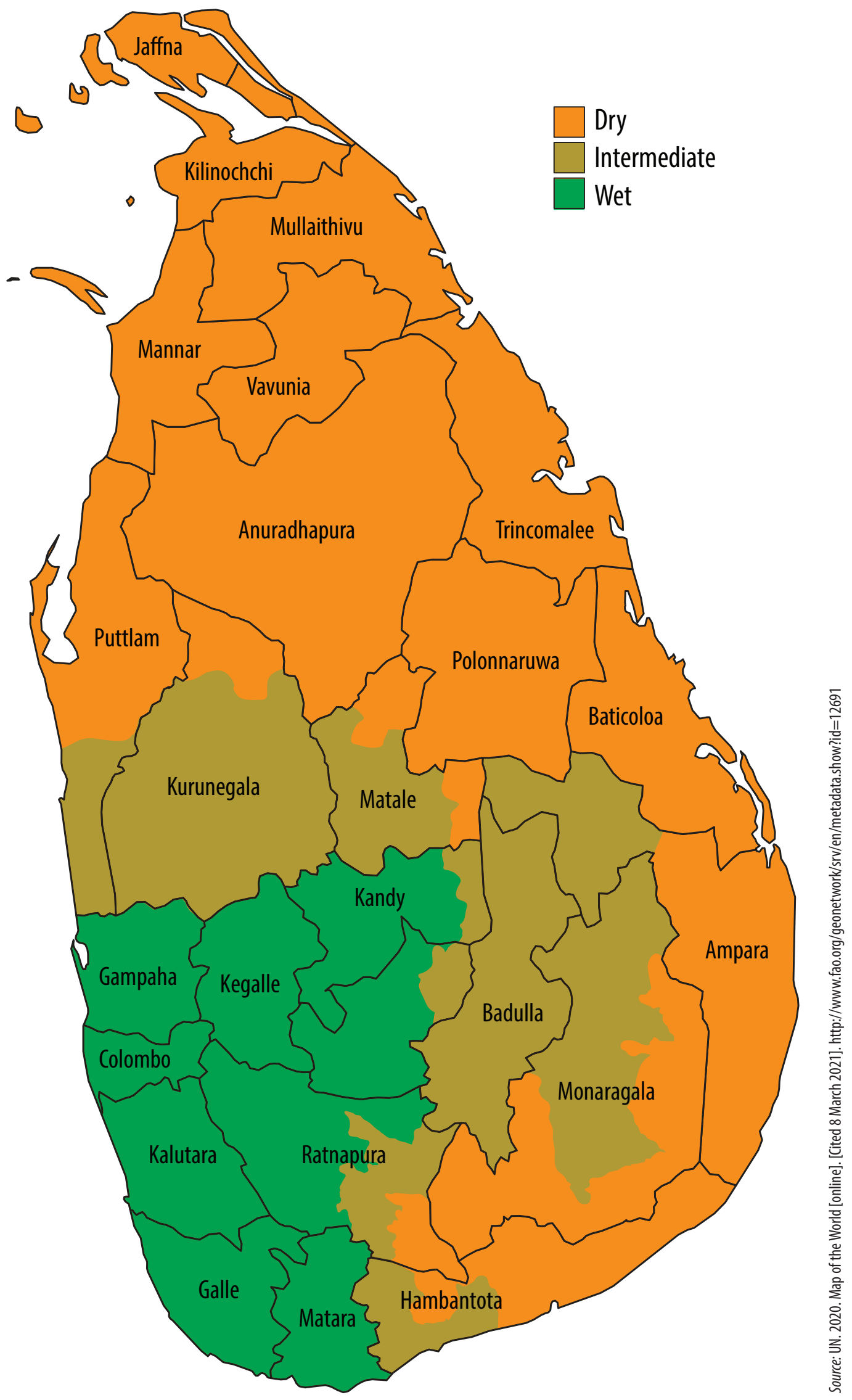

Figure 3. Sri Lanka districts per climatic zone 
Here, for each yield data set, four of the most frequently used methods are compared:
1) Linear
2) Polynomial (up to order 3)
3) Log-linear (logarithmic transformation of yields)
4) Linear-log (logarithmic transformation of years)

A threshold is imposed on the adjusted $\mathrm{R}^{2}$ of the fit of 0.2 , and - from the models meeting this preliminary condition - the one that produces the minimum autocorrelation of residuals, as measured by the Durbin-Watson test, is selected. The trend is then subtracted from the actual yield, in order to obtain the anomaly, which is assumed to capture most of the crop response to climate and soil water balance variables.

\subsection{Modelling soil water balance}

The crop-specific soil water balance model embedded in MOSAICC is WABAL (WAter BALance). A tool for evaluating water requirements and satisfaction at various growth stages for a specific crop, at a given location characterized by climate and soil, WABAL is also the water balance component of the crop model FAO-AgroMetShell (Mukhala and Hoefsloot, 2004).

WABAL uses a 10-day interval to solve the water balance equation for the soil-crop system. The interval of 10 days is termed "dekad" in FAO Drainage and Irrigation Papers, where it is preferred to daily or monthly intervals, as it provides sufficient time resolution while reducing the highly fluctuating effects of daily data. Given the soil water holding capacity (WHC), the available water stored in the soil (Wa) is calculated as:

$$
W a=W p+R a+I r r-E T a-\text { Losses }
$$

Wa is the amount of available soil water at the end of each dekad, calculated as the sum of the available soil water stored in the soil at the end of the previous dekad (Wp), rainfall ( $\mathrm{Ra}$ ) and (where appropriate) irrigation (Irr), minus the amount evaporated and transpired by the crop (ETa: crop actual evapotranspiration) and water losses related to surface runoff and/or deep infiltration. Each time Wa falls below a certain user-defined threshold, it is set to that threshold and water deficit is recorded; when Wa exceeds WHC, it is set to WHC and water excess is recorded (Table 5).

The calculation of ETa requires rainfall data, reference evapotranspiration ETo (calculated through the Hargreaves and Samani equation within MOSAICC), crop planting and harvesting dates, and phenology data. Without water limitation, ETa equals the maximum crop evapotranspiration (ETc) calculated according to FAO Irrigation and Drainage Paper No. 56 (FAO, 1998) as:

$$
E T c=K c \cdot E T o
$$


Table 5. WABAL outputs

\begin{tabular}{|l|l|}
\hline Variable & Definition \\
\hline ETa $_{\mathbf{i}}$ & Actual evapotranspiration $(\mathrm{mm})$ \\
\hline DEF $_{\mathbf{i}}$ & Water deficit $(\mathrm{mm})$ \\
\hline EXC $_{\mathbf{i}}$ & Water excess $(\mathrm{mm})$ \\
\hline TWR & Total water requirement (mm) \\
\hline WSI (raw) & Water satisfaction index (\%) \\
\hline WSI (corr) & WSI corrected to account for water excess (\%) \\
\hline
\end{tabular}

Note: The subscript i denotes: 1-initial, 2-development, 3-mid-season, 4-late-season and $\mathrm{t}$-total, for each variable in the table indicated with the subscript $\mathrm{i}\left(\mathrm{ETa}_{\mathrm{i}^{\prime \prime}}, \mathrm{DEF}_{\mathrm{i}^{\prime}} \mathrm{EXC}\right.$ ), resulting in 15 outputs. The remaining three variables (TWR, WSI [raw], WSI [corr]) without subscript $\mathrm{i}$, refer to the whole growing cycle. The overall sum is $15+3=18$ outputs. with the crop coefficient $(\mathrm{Kc})$ varying along the growing cycle. MOSAICC adopts the four-phase, single crop coefficient approach, where the growing cycle is divided into initial, development, mid and late development stages, and the water balance equation is solved subsequently for each phase. Each of the four phases is characterized by the crop coefficient $\mathrm{Kc}_{\mathrm{i}}$ (i.e. the ratio between maximum crop evapotranspiration $[\mathrm{ETc}]$ and reference evapotranspiration [ETo]) and a crop factor that quantifies the duration of growth stage

(see subsection 2.1). Both the crop factors $\left(\mathrm{F}_{\mathrm{i}}\right)$ and crop coefficients $\left(\mathrm{Kc}_{\mathrm{i}}\right)$ are provided as input data to WABAL for calculating the water balance along the whole growing cycle (Table 3). Figure 4 illustrates the crop development curve according to this approach: WABAL outputs are synthetically defined in Table 5. They describe water balance conditions at four growth stages and during the whole growing cycle, "i” being: 1-initial, 2-development, 3-mid-season, 4-late-season or t-total. As the analysis is carried out at the district level, the WABAL model needs climate data as input at this spatial level in order to make consistent regression between climate, water balance and yield variables. For this reason, local observations for the period 1994-2016 were interpolated using the AURELHY method (Bénichou and Le Breton, 1987).

Climate data at 33 stations for the period 1994-2016 were selected for the interpolation and the analysis because the AURELHY method requires both a long historical period of observations (temporal criteria) and a dense network of measurements (spatial criteria).

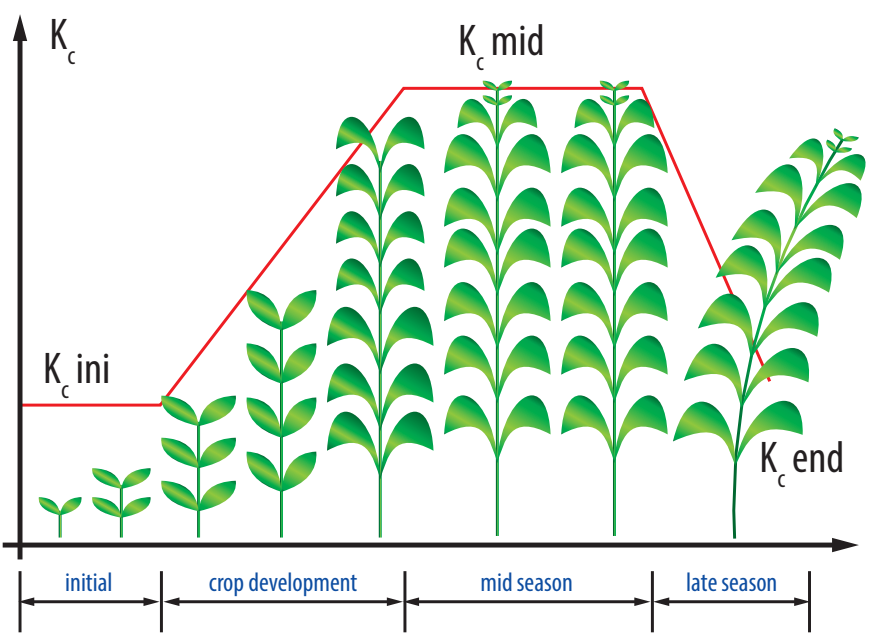

Figure 4. Generalized crop coefficient curve for the single crop coefficient approach

\subsection{Building the yield function}

MOSAICC combines the water balance calculation at dekadal time resolution with a statistical approach to crop modelling. The relationship between the yield anomaly (Ym) and climate and soil water balance variables $\left(\mathrm{X}_{\mathrm{i}}\right)$ is investigated through correlation and regression analysis, with potential predictors among climate and water balance variables. This leads to the definition of a "yield function" as follows: 


$$
Y m=a_{1} X_{1}+\ldots+a_{i} X_{i}+\ldots+a_{n} X_{n}+b
$$

Variables $\mathrm{X}_{\mathrm{i}}$ can be climate (e.g. Tmin, Tmax, Prec) and/or WABAL output variables (e.g. ETa, WSI), either averaged at specific stages of the growing cycle or aggregated over the whole year/growing cycle.

This study considered as potential predictors $\mathrm{X}_{\mathrm{i}}$ both the water balance WABAL parameters (18 water balance variables - see Table 5) and the climate variables (Tmax, Tmin, Prec) averaged over the four growing stages (see subsection 2.4) and over the whole growing season: $\operatorname{Tmax}_{\mathrm{i}}$, $\operatorname{Tm}_{\mathrm{in}}$, Prec $_{i}$ where the subscript i denotes 1-initial, 2-development, 3-mid-season, 4-late-season and t-total (15 climate variables in total).

This gives a total of 33 potential predictors: 18 WABAL outputs (Table 5) plus 15 climate variables. Yield functions can be affected by several sources of uncertainty (Yao et al., 2011), including:

1) measurement uncertainties in climate data;

2) length and completeness of historical climate data set;

3) accuracy and completeness of yield data;

4) reliability of "detrending hypothesis" (non-climatic factors removed by detrending);

5) quality of trend model;

6) accuracy and completeness of crop phenology and calendar information;

7) accuracy of models for crop evapotranspiration and water balance calculation; and

8) collinearity among regressors.

Acknowledging the above-mentioned limitations, statistical crop models remain a valuable tool for understanding and estimating crop yields, with both advantages and drawbacks when compared to more complex "crop growth" or "process-based" models. In their multiple variants (time series, panel, random coefficient models etc.) with a variety of criteria in the pool and a choice of predictors, they have been successfully applied in long-term analysis of past climate, future longterm projections and seasonal forecasts (Genovese et al., 2004; Lobell and Burke, 2010; Shi, Tao and Zhang, 2013; van der Velde and Nisini, 2019; Vogel et al., 2019).

As a specific feature of statistical crop models, the most crucial aspect is the selection of potential predictors (or regressors/explanatory variables) and the statistical criteria adopted to assess the quality of the regression. To select the explanatory variables in the yield functions, the stepwise AIC (Akaike information criterion) method is adopted, implemented in the R-package "MASS" (Venables and Ripley, 2002), combining forward and backward selection.

A total of 33 potential predictors is much higher than the number of observations (22 years of observations). This dimension difference could render unstable the result of a stepwise selection (George, 2000). Therefore, to reduce the initial pool of potential predictors, a preliminary selection is performed by keeping in the "full model" only the $\mathrm{n}_{\mathrm{obs}}-1=21$ among climate and water balance 
parameters mostly correlated with yield anomaly. If the number of predictors of the stepwiseselected model exceeds three, less-correlated potential predictors are recursively removed from the "full model" until a final model with a maximum of three independent variables is attained.

To deal with multicollinearity - i.e. predictors correlated between each other - another recursive process is applied in the case that the stepwise-selected regression model contains predictors with a variance inflation factor $>4$ (Hair et al., 1995). In this case, the predictor most highly correlated with yield anomaly is kept, while the predictor with the highest correlation with that one is removed; the stepwise method is then applied again with the reduced pool of potential predictors. There is seldom need for this further reduction (only 3 cases out of 73), meaning that the stepwise AIC method effectively gets rid of multicollinearity in most cases.

The quality of the model is evaluated in terms of adjusted $\mathrm{R}^{2}$, $\mathrm{p}$-value and cross-validation $\mathrm{R}^{2}$ (see Tables 7-12, last three columns). For validation of the models, considering the absence of independent data sets and the relatively limited number of observations (22 years), the leave-one-out cross-validation (LOOCV) option is selected, thus removing recursively one single year from the data set, using the remaining 21 years to fit the model and the single removed year for validation.

The cross-validation method implemented in the R library "caret" is used in this study. This approach has been adopted in other statistical crop modelling studies (Kern et al., 2018; Santos et al., 2010).

\subsection{Projecting future yield changes}

Future yield anomalies are the result of the yield function defined above (Ym) applied under future modelled climate and water balance conditions. As for the climate data (precipitation, maximum and minimum temperature), six different general circulation models (GCMs) from the Coupled Model Intercomparison Project Phase 5 (CMIP5 - Taylor, Stouffer and Meehl [2012]), which have been extensively used in climate change impact assessments, were available for this study. Apart from particular parameterization schemes, they differ mainly in their spatial resolution. Allowing for a good characterization of the uncertainty that typically arises in climate change studies associated with the choice of GCM (Chen, Xu and Guo, 2012; Dibike and Coulibaly, 2005), daily precipitation, maximum and minimum temperature provided by these GCMs were downscaled by means of statistical techniques in order to provide daily downscaled precipitation, and maximum and minimum temperatures for the country's 33 weather stations until 2100 under two representative concentration pathways: RCP4.5 and RCP8.5. RCPs provide

Table 6. The six CMIP5 GCMs used in the study

\begin{tabular}{|l|l|l|}
\hline \multicolumn{1}{|c|}{ GCM label } & Institution acronym and country & \multicolumn{1}{c|}{ Reference } \\
\hline CanESM2 & CCCMA (Canada) & (Chylek et al., 2011) \\
\hline CNRM-CM5 & CNRM-CERFACS (France) & (Voldoire et al., 2013) \\
\hline GFDL-ESM2M & NOAA GFDL (USA) & (Dunne et al., 2012) \\
\hline IPSL-CM5A-MR & IPSL (USA) & (Dufresne et al., 2013) \\
\hline MIROC-ESM & MIROC (Japan) & (Watanabe et al., 2011) \\
\hline MPI-ESM-MR & MPI (Germany) & (Jungclaus et al., 2010) \\
\hline
\end{tabular}


one of the many possible scenarios that would lead to specific radiative forcing characteristics. In particular, while RCP4.5 (Thomson et al., 2011) is an intermediate pathway in which radiative forcing is expected to stabilize at approximately $4.5 \mathrm{~W} / \mathrm{m}^{2}$ after $2100, \mathrm{RCP} 8.5$ (Riahi et al., 2011) is a high pathway for which radiative forcing is expected to reach $>8.5 \mathrm{~W} / \mathrm{m}^{2}$ by 2100 and then continue to rise. Additionally, the six GCMs were also downscaled for their historical scenario, providing the baseline climate for the locations of interest (the 33 national weather station locations). For precipitation, the analogue technique was used (Lorenz, 1969), whereby the local downscaled values corresponding to a particular atmospheric configuration (as represented by the different GCMs in the future) were estimated on the basis of the local observations corresponding to the most similar atmospheric configurations, as given by reanalysis in a historical period (Zorita et al., 1995). On the other hand, for maximum and minimum temperature, multiple linear regression was conducted using predictor information at the nearest grid box.

Multiple linear regression attempts to model the relationship between two or more predictors and a response variable by minimizing the sum of the residuals between a fitted regression line and the observed data (Helsel and Hirsch, 2002). It should be noted that the analogue technique is not suitable for temperatures given its inability to extrapolate values out of the observed range, which may constitute an important issue in the context of a changing climate (Gutiérrez et al., 2013). In all cases, a common predictor set comprising temperature, relative humidity, zonal and meridional winds at $850 \mathrm{hPa}$ was used, maximizing the inter-variable consistency of downscaled future scenarios.

The local downscaled climate projections were subsequently interpolated using AURELHY (Bénichou and Le Breton, 1987) in order to obtain a regular grid of climate information suitable to be used at the geographic unit of the analysis (the districts).

Historical and future water balance conditions were then simulated with WABAL based on the downscaled and interpolated climate data at dekadal time resolution and district level, and the yield changes were calculated as the difference between simulated Ym for the future and baseline periods. These differences or "changes" are calculated for three different time frames (near, middle and far future, up to 2100). Note that the results of this study are limited to the middle and far future. 


\section{Results}

This section presents time series of cultivated areas, yields and yield anomalies (detrended yields) at both the country and the district level (subsections 3.1 and 3.2), and the results of the full analysis, with correlation, regression and future projections at the district level (subsections 3.3 and 3.4).

\subsection{Cultivated area and yield trends at the national level}

This section provides a country-level overview of the crop sector with time series of cultivated area and yield for the selected crops. Analyses are carried out at the district level to account for the heterogeneous

Rice

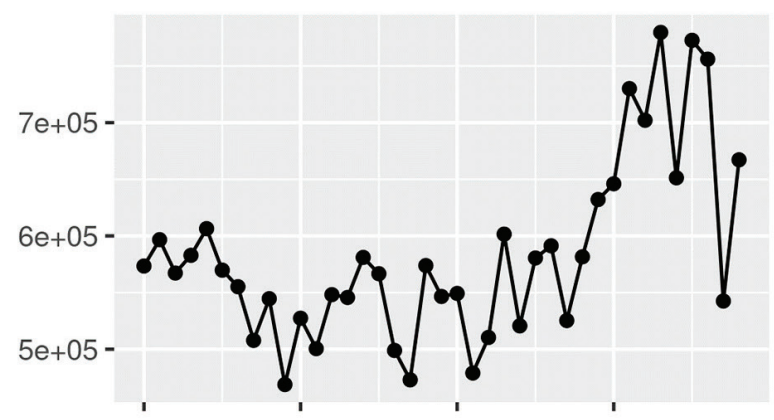

Green gram

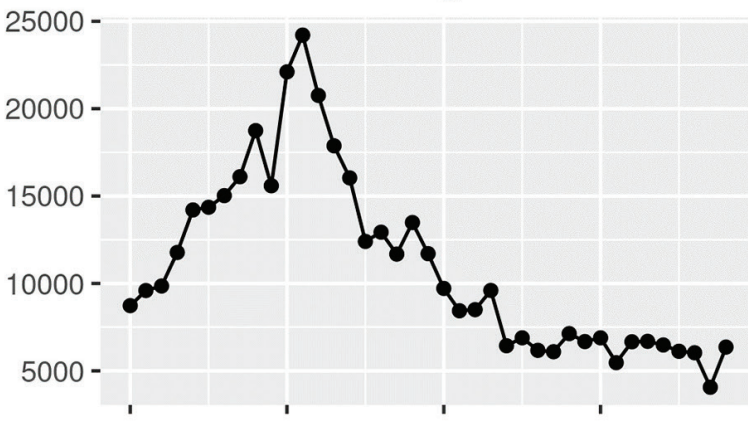

Big onion

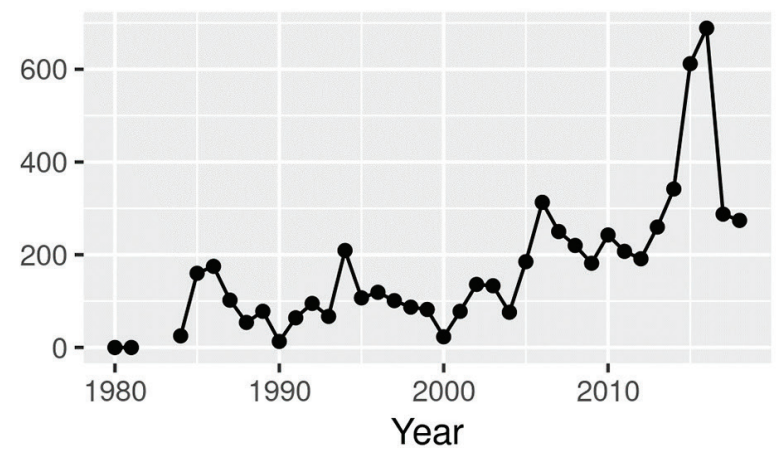

Maize

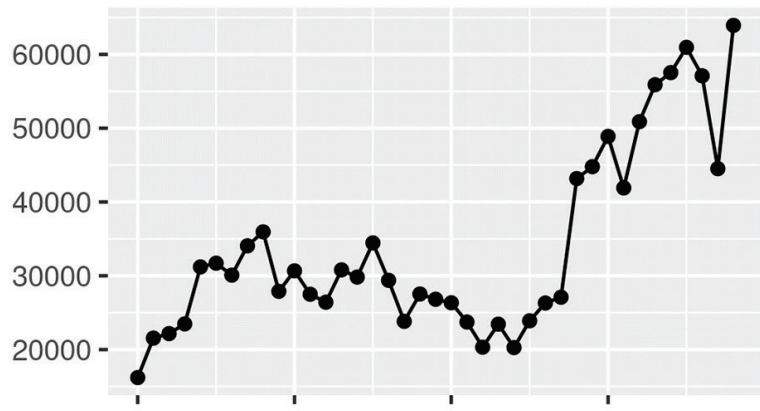

Potato

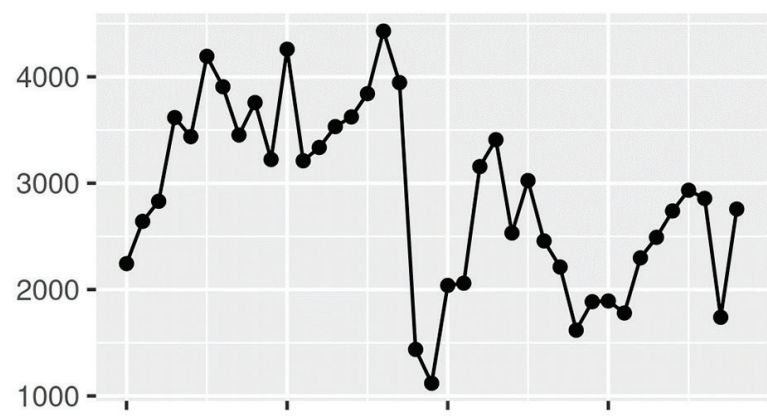

Chilli

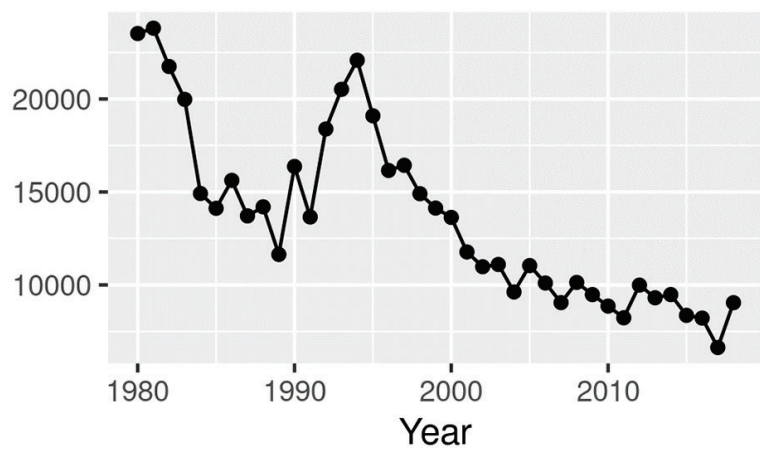


climate and agro-ecological characteristics of Sri Lanka (see Section 1). Figures 5 and 6 show the time series of cultivated area of the six crops from 1980 to 2018 for the Maha and Yala seasons, respectively. Trends and fluctuations likely reflect the variation in interest and investment (increasing/decreasing) in the specific crops for their changing role and importance, as well as changes in farmers' practices from less to more extensive and vice versa.

Rice

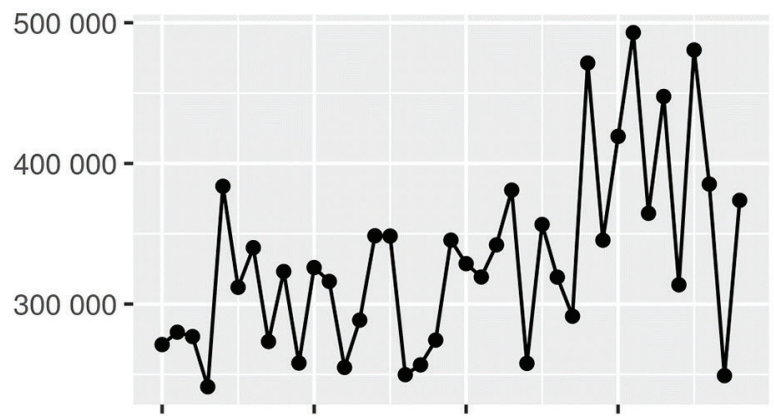

Green gram

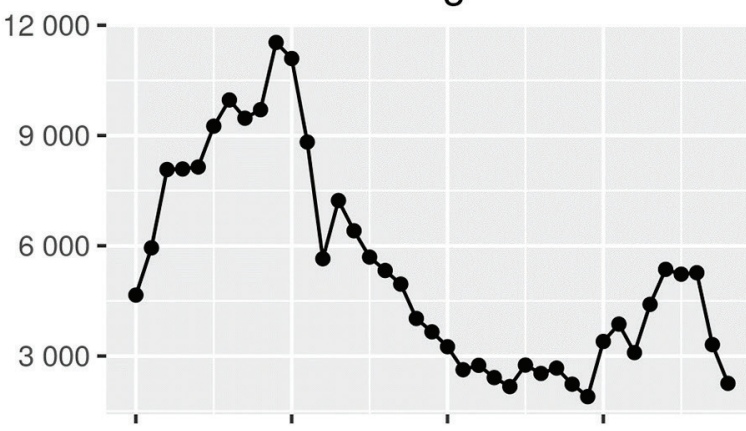

Big onion

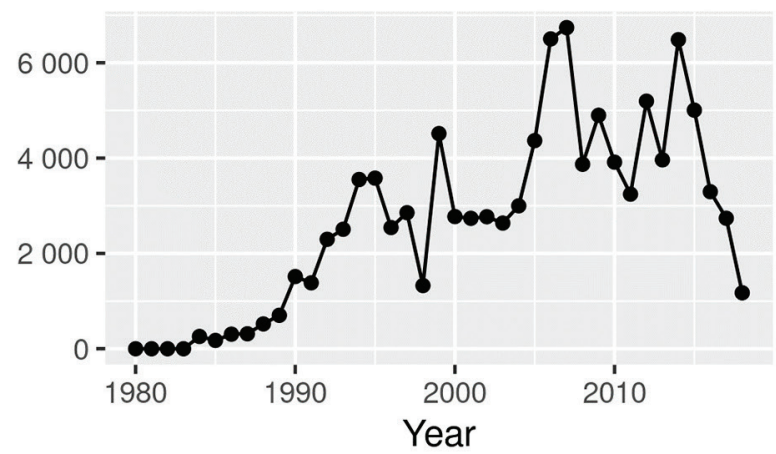

Maize

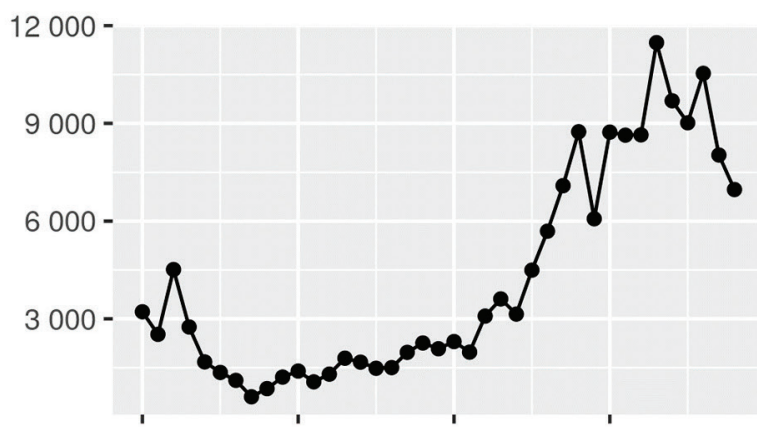

Potato

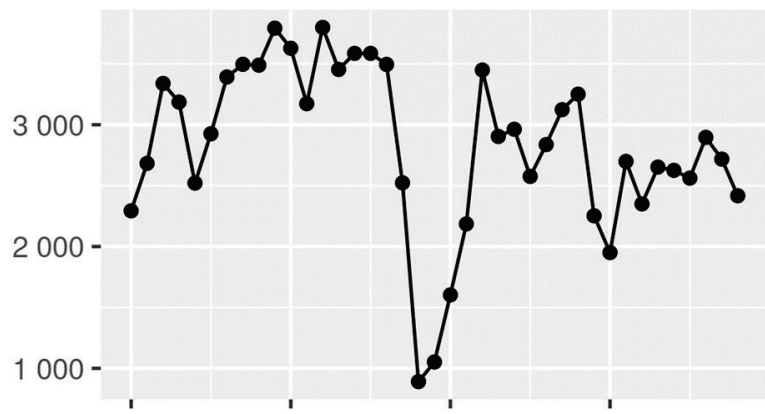

Chilli

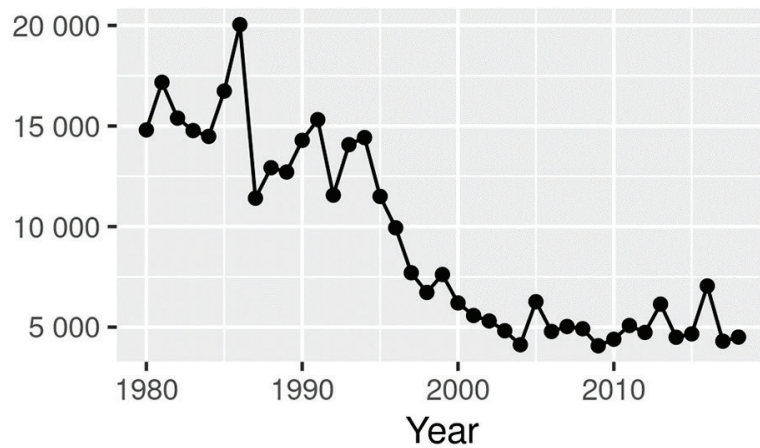

Figure 6. National cultivated area for the Yala season (ha)

Figures 7 and 8 show the average yields of the six crops at the national level for the same period (1980-2018) for the Maha and Yala seasons, respectively. Trends and fluctuations in yield mostly reflect the response of the crop to management, technology and climate variations. All the Maha crops (Figure 7) reveal an overall increasing trend in yields after the 1980s (2000 for big onion). 
Linear-log fit is the best fit for rice, while for the other crops, polynomial curves better represent the long-term trend of the yield over the last 25 years. For these crops, the last decade shows a strong increasing trend, while the earlier period is characterized by a less marked increase, or by a stagnating or decreasing trend.

Rice

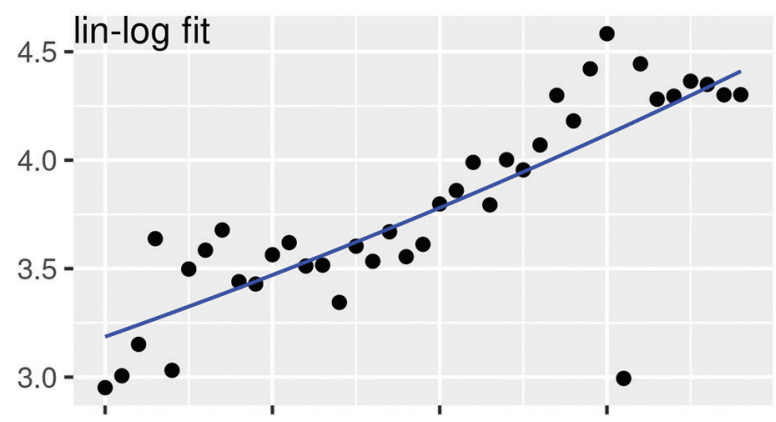

Green gram

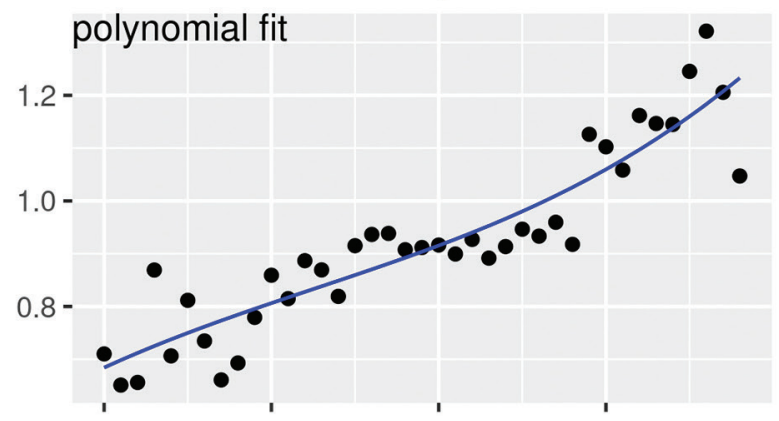

Big onion

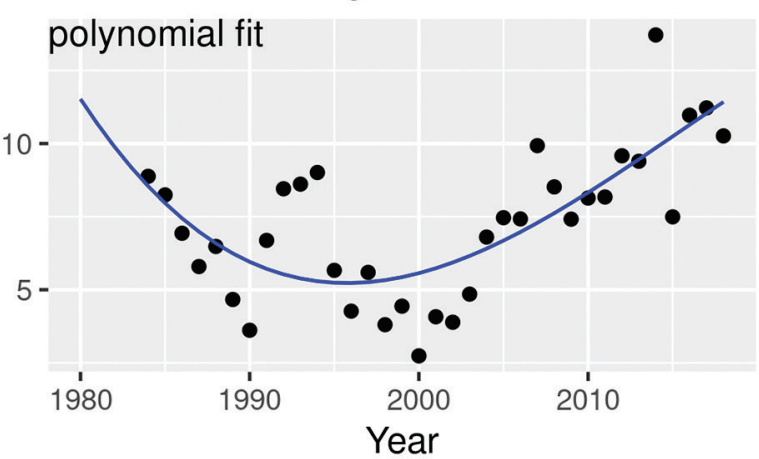

\section{Maize}

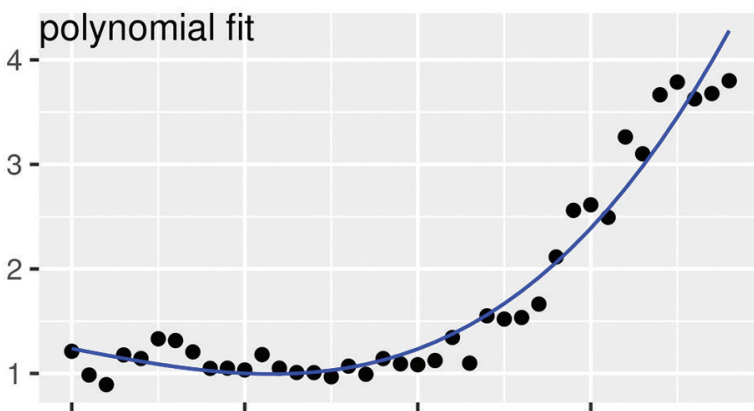

Potato

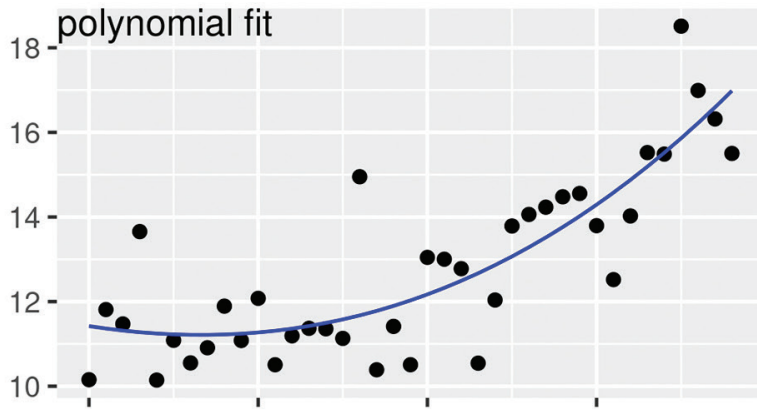

Chilli

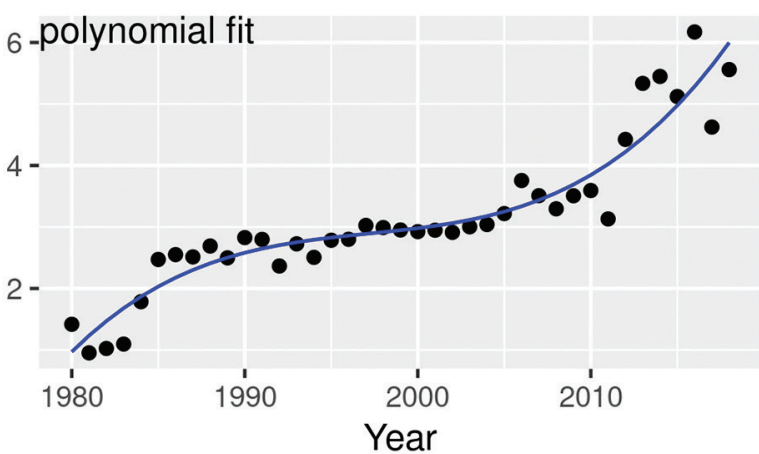

Figure 7. Average national yields for the Maha season (tonnes/ha)

For the Yala season (Figure 8), yield trends are generally more irregular, with all crops following a non-linear trend. Assuming that these long-term trends are not related to current climate variability, they could be the result of changes in plot/farm management, policies and technology. Results also suggest higher variability of these factors during the Yala season than in the Maha season. 
Rice

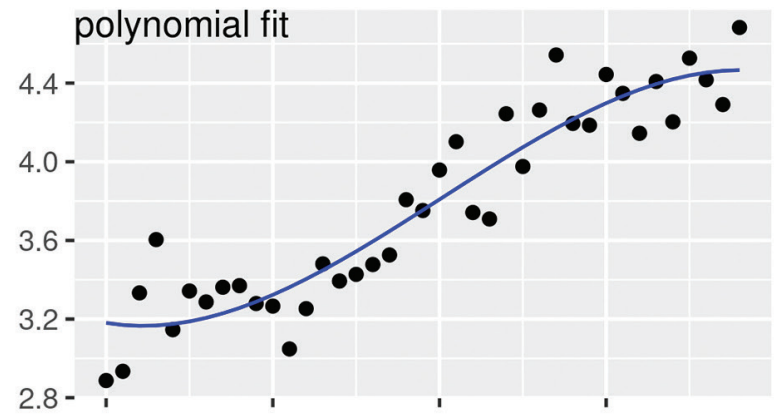

\section{Green gram}

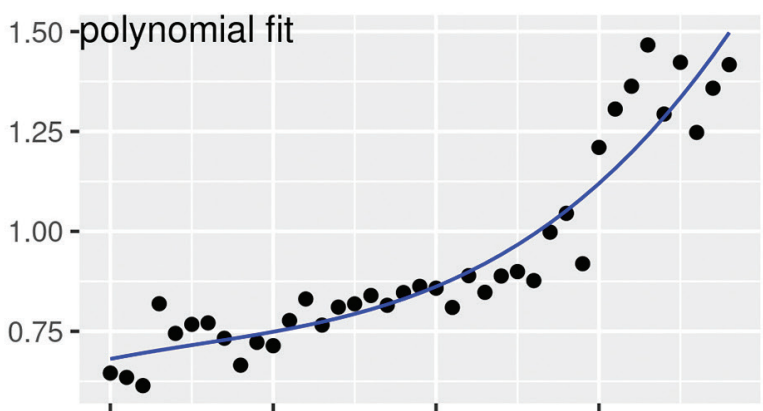

Big onion

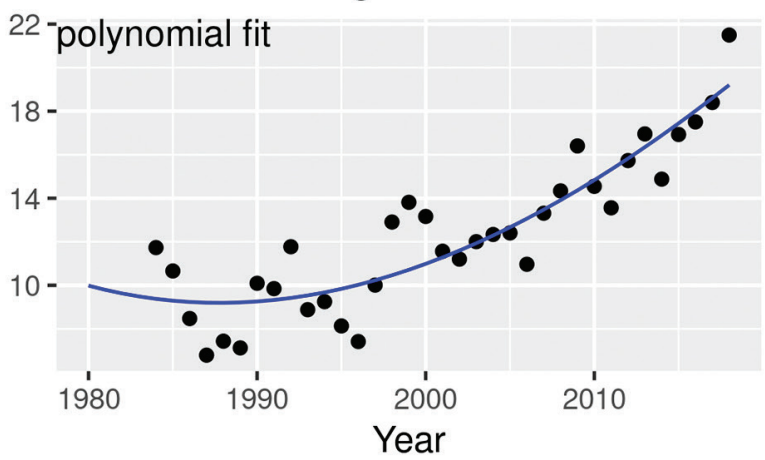

Maize

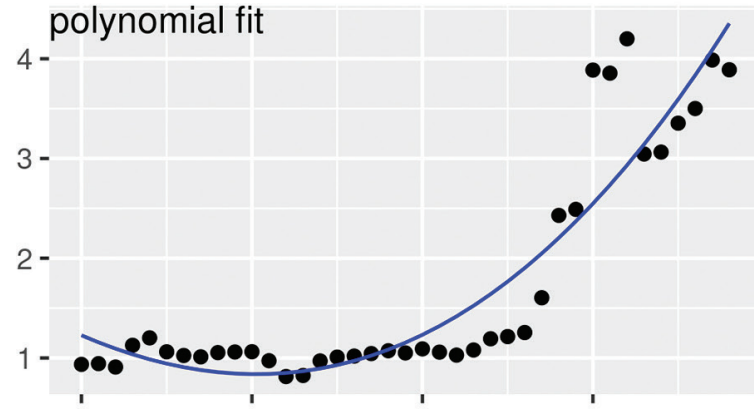

\section{Potato}

polynomial fit

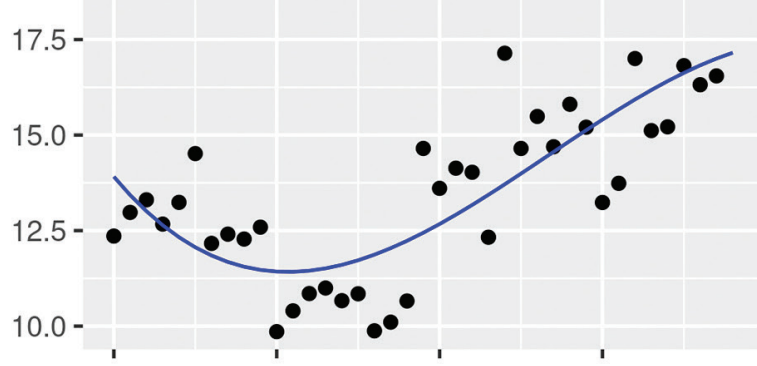

Chilli

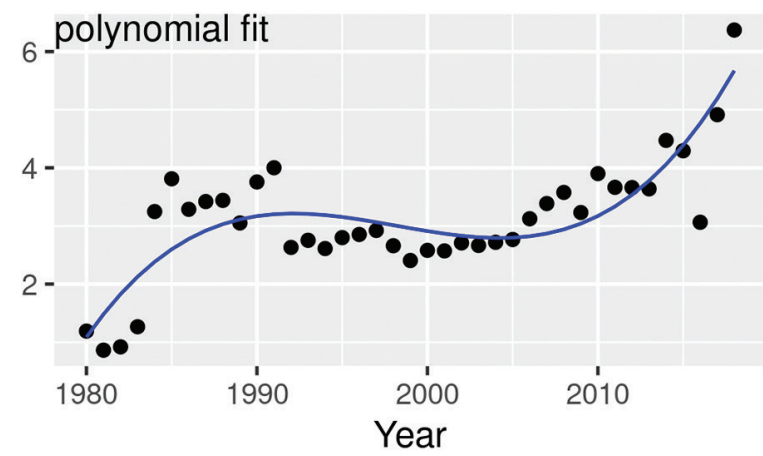

Figure 8. Average national yields for the Yala season (tonnes/ha) 


\subsection{Cultivated area, yield trend and anomaly at the district level}

Yield functions and yield change projections are carried out at the district level, because small-scale impact assessments allow to better identify the relationship between climate and crop yield since climate, soil characteristics and agricultural practices are more homogeneous across the study area. Figures A1-A34 in this subsection refer to the graphs of cultivated area, yield and anomalies found in the Appendix.

\section{Rice}

For both Maha and Yala seasons, the area under irrigation is higher than the rainfed area. The districts of Ampara and Polonnaruwa located in dry zone have the highest cultivated areas (> 50000 ha) in both Yala and Maha seasons with irrigation (Figures A1-A3).

The yields under rainfed conditions are smaller than the yields under irrigation in both seasons (Figures A4-A6). Indeed, given that water is a limiting factor, short-duration rice is generally cultivated under rainfed conditions and it provides lower yields than the medium- and longduration rice that tends to be cultivated under irrigated conditions.

During the last 30 years, all districts cultivated with rice have witnessed a continually increasing trend in yield, irrespective of the season and irrigation regime - albeit more pronounced and smoother in the Maha season. These increasing trends (at both the national and the district level) likely reflect the Government's supporting policies aimed at maintaining self-sufficiency in rice production and consumption, discouraging rice imports, promoting export and favouring initiatives such as donations (in 2011, Sri Lanka donated 7500 tonnes of rice to the World Food Programme).

\section{Maize}

Maize is mainly grown in the Maha season (Figures A10 and A11). In the Yala season, maize cultivation is practised in the lowlands (where rice is cultivated during the Maha season). Anuradhapura and Moneragala, located in the dry zone have the highest extent (>10 $000 \mathrm{ha}$ ) of maize cultivation in the Yala season, thanks to favourable climatic conditions and water availability (while the water requirement of maize is high, it is nevertheless less than for rice). In the Maha season, the lowlands are used mainly for rice and the remaining lowlands and uplands are used to cultivate the other field crops.

Yields and trends are shown in Figures A12 and A13 for the Maha and Yala seasons, respectively. In all maize districts, maize yield has shown an increasing trend in the last 30 years - prominent in both seasons. These increasing trends most likely reflect the supporting policies of the Government of Sri Lanka in maintaining maize production and consumption and promoting export. 


\section{Big onion}

Big onion is extensively cultivated only in the Yala season. Matale, Anuradhapura, Polonnaruwa and Kurunegala, located in the dry and intermediate zones, contribute the greatest extent of big onion cultivation due to the favourable climatic conditions (higher day length) and water availability.

A significant proportion of the total land area of Matale and Anuradhapura is dedicated to big onion cultivation, accounting for a considerable part of the total national cultivated area for this crop. There has been an increasing trend in the area under big onion in Matale and Anuradhapura during the last 30 years (Figure A16) - most likely a reflection of the supporting policies of the Government of Sri Lanka in maintaining big onion production and consumption, reducing big onion imports, and promoting production of seed onion.

Figure A17 presents yield and trend for big onion cultivation. Yield in Matale District shows an increasing trend, while in Polonnaruwa and Kurunegala the trend shows a parabolic shape, decreasing through to 2000 and then increasing.

\section{Green gram}

The extent of cultivated green gram during the Maha season is higher than in the Yala season (Figures A19 and A20). The districts of Moneragala and Hambantota, located in the dry and intermediate zones, contributed the highest extent of green gram cultivation with favourable climatic conditions and water availability (water requirement is less than for rice). In the Yala season, green gram is mainly cultivated in the lowlands. In the Maha season, priority is given to rice in the lowlands and the remaining lowlands and uplands are used to cultivate other field crops, including green gram.

The last 30 years have seen a decreasing trend in the area under green gram in Moneragala, Hambantota, Kurunegala and Puttalam in the Maha season and in Moneragala and Kurunegala in the Yala season. This decreasing trend is due in part to the law on market prices and in part to agronomic problems (pests and diseases, weeding) and socio-economic factors (labour, fertilizer and seed costs). However, in Hambantota District there has been an increasing trend in the Yala season - most likely a reflection of the government strategies to support green gram production as a new agronomic cultivation practice.

Yields and trends are shown in Figures A21 and A22 for the Maha and Yala seasons, respectively. Several districts present an oscillating behaviour from year to year, typical of green gram.

\section{Potato}

Potato cultivated areas are similar during the Yala and Maha seasons (Figures A25 and A26). Owing to a wider diurnal temperature regime, the districts of Badulla and Nuwara Eliya, located in the 
intermediate and wet zones, show the highest extent of potato cultivation, while in Jaffna, the crop is grown only during the Maha season.

The cultivated area in Nuwara Eliya and Badulla reveals an increasing or stagnating trend over the last 30 years, more pronounced in the Maha than in the Yala season. In contrast, there has been a decreasing trend in Jaffna District, due to the consequences of the civil war; nevertheless, also in this district the cultivated extent has revealed an increasing trend in recent years. These increasing trends most likely reflect the policies of the Government of Sri Lanka aimed at maintaining potato production and consumption and promoting production of potato seeds.

Yields and trends are shown in Figures A27 and A28 for the Maha and Yala seasons, respectively. All the districts show an overall increasing trend, with Nuwara Eliya presenting a decreasing trend (reaching a minimum in the 1990s) followed by an increasing trend.

\section{Chilli}

Figures A31 and A32 show that the Maha season contribute more than the Yala season to the total annual cultivation of chilli. Anuradhapura, Puttalam, Moneragala, Kurunegala and Badulla, located in the dry and intermediate zones, make a significant contribution due to the favourable climate conditions (greater day length) and water availability.

The cultivated area in Anuradhapura represents the highest fraction of district extent and of national cultivated area. In the Yala season, Puttalam has shown an increasing trend in the last 30 years, while the increasing trend in the other districts was more marked in the Maha season.

Yields and trends are shown in Figures A33 and A34 for the Maha and Yala seasons, respectively. All the chilli cultivated districts showed an increasing trend in both the Yala and the Maha seasons.

\subsection{Regression models (yield functions)}

This subsection reports the yield functions for the two seasons Yala and Maha. For rice, season regards both irrigated and rainfed rice, and the Yala season only irrigated rice.

The relevant districts vary according to season and irrigation (depending on water availability). Rice is grown under both irrigated and rainfed conditions, while other crops are cultivated only with supplemental irrigation. In general, more districts are cultivated during the Maha season, when a larger area in the dry zone becomes suitable for cultivation (see Table 4). This leads to the 73 different yield functions shown in Tables 7-12.

Tables 7-12 show that, for the different crops, districts, seasons and irrigation modes, the selected climate and water balance variables explain $0.06-0.9$ of the variance in yields, with $\mathrm{R}_{\text {adj }}^{2}$ mean and 
median values of 0.38 and 0.41 , respectively. Cross-validation $\mathrm{R}^{2}$ are generally 10 percent lower than the full model $\mathrm{R}_{\text {adj }}^{2}$ for the highest $\mathrm{R}_{\text {adj }}$ cases, showing generally a good explicative and predictive power of the yield functions.

When the $\mathrm{R}_{\text {adj }}$ of the yield function falls below 0.2, or the stepwise selection does not meet minimum quality criteria (high number of missing or repeated values in predictors), the yield function is not considered for future projections. This happens for 14 of the 73 yield functions, and the corresponding districts are indicated between square brackets in Tables 7-12. In all the other cases, the yield functions are significant to the 10 percent level, and in most cases to the 5 percent level ( $\mathrm{p}$-value column in Tables 7-12).

\section{Rice}

Rice is cultivated in both the Maha and Yala seasons, in different districts (see Table 4). During the Maha season, rainfall provides sufficient water to cultivate rice without irrigation, while during the Yala season, rice is irrigated. The districts relevant for rice production differ depending on the season and the irrigation regime, due to the differences in water availability.

Generally, water balance parameters appear slightly more frequently as predictors in the yield functions than do climate variables, especially in the Yala season (Table 7). Among these, water excess (EXC) generally shows a negative impact on yield during the last growing stage $\left(\mathrm{EXC}_{4}\right)$, while during the first and second stage $\left(\mathrm{EXC}_{1}\right.$ and $\left.\mathrm{EXC}_{2}\right)$, it can appear in the yield functions with positive coefficients.

During the Maha season (rainfed regime), water deficit generally presents negative coefficients as well as maximum and minimum temperatures, especially for the most significant models. Anuradhapura, in the dry zone, shows a yield function with negative coefficients for precipitation variables, most likely due to negative impacts of floods affecting this lowland area in the Maha season.

For the Maha season (irrigated regime), the water balance parameter EXC appears more frequently than under the rainfed regime. Usually, water excess has negative coefficients, suggesting that with irrigation, the intense rains characteristic of the northeast monsoon lead to more severe damage, generating yield losses. Actual evapotranspiration predictors under this regime appear with positive coefficients, suggesting that with irrigation, higher evapotranspiration is related to increased plant growth.

During the Yala season (irrigated regime), water balance parameters appear as predictors more frequently than do climate variables. Precipitation and water deficit appear with positive and negative coefficients respectively, suggesting that water scarcity can still lead to damage and yield losses during the Yala (drier) season, in spite of irrigation being in place. 
Table 7. Yield functions for rice per season, irrigation regime and district

\begin{tabular}{|c|c|c|c|c|c|c|}
\hline & & District & Yield function & $\mathbf{R}_{\text {adj }}^{2}$ & p-value & $\mathbf{R}_{c v}^{2}$ \\
\hline \multirow{8}{*}{ 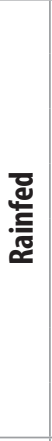 } & \multirow{8}{*}{ 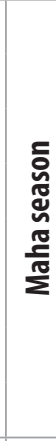 } & Batticaloa (DZ) & $\mathrm{Y}=5.869+0.028$ Prec $_{1}-0.001 \mathrm{DEF}_{\mathrm{t}}-0.167 \mathrm{Tmax}_{1}$ & 0.463 & 0.0034 & 0.307 \\
\hline & & Ampara (DZ, IZ) & $Y=-0.597-0.002 \mathrm{EXC}_{4}+0.022 \mathrm{WSI}$ (corr) $-0.001 \mathrm{DEF}_{\mathrm{t}}$ & 0.453 & 0.0039 & 0.355 \\
\hline & & Kurunegala $(\mathrm{IZ}, \mathrm{DZ})$ & $\mathrm{Y}=4.079-0.008 \mathrm{Prec}_{1}+0.004 \mathrm{ETA}_{4}-0.21 \mathrm{Tmin}_{2}$ & 0.445 & 0.0044 & 0.365 \\
\hline & & Anuradhapura (DZ) & $Y=1.264-0.01$ Prec $_{2}-0.004$ Prec $_{3}$ & 0.427 & 0.0034 & 0.205 \\
\hline & & Kalutara (WZ) & $Y=-5.02+0.002 \mathrm{EXC}_{1}+0.25 \mathrm{Tmin}_{3}-0.008 \mathrm{WSI}$ (corr) & 0.35 & 0.0158 & 0.197 \\
\hline & & Galle (WZ) & $\mathrm{Y}=-3.057-0.035 \mathrm{ETA}_{1}+0.024 \mathrm{ETA}_{2}+0.001 \mathrm{EXC}_{2}$ & 0.277 & 0.0366 & 0.161 \\
\hline & & Moneragala (IZ, DZ) & $\mathrm{Y}=-9.495-0.005 \mathrm{Prec}_{2}+0.289 \mathrm{Tmin}_{2}+0.016 \mathrm{ETA}_{3}$ & 0.25 & 0.0487 & 0.108 \\
\hline & & Kilinochchi (DZ)* & $\mathrm{Y}=-17.286+0.525 \operatorname{Tmax}_{2}+0.002 \mathrm{EXC}_{2}$ & 0.141 & 0.1597 & 0.004 \\
\hline \multirow{17}{*}{ 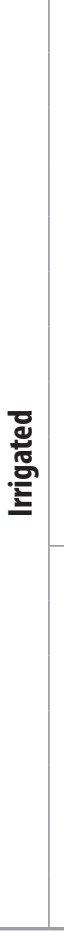 } & \multirow{10}{*}{ 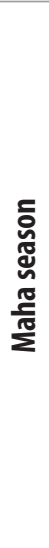 } & Trincomalee (DZ) & $Y=-5.567-0.003 \mathrm{EXC}_{4}+0.009 \mathrm{ETA}_{\mathrm{t}}+0.008$ Prec $_{1}$ & 0.906 & 0 & 0.833 \\
\hline & & Polonnaruwa (DZ) & $Y=4.474-0.001 \mathrm{EXC}_{4}-0.309 \mathrm{Tmax}_{4}+0.008 \mathrm{TWR}$ & 0.693 & 0 & 0.604 \\
\hline & & Mannar (DZ) & $\mathrm{Y}=-13.122-0.012 \mathrm{Prec}_{2}+0.037 \mathrm{ETA}_{2}+0.244 \operatorname{Tmax}_{2}$ & 0.687 & $2.00 \mathrm{E}-04$ & 0.559 \\
\hline & & Ampara $(I Z, D Z)$ & $Y=0.019-0.002 \mathrm{EXC}_{4}+0.016$ Prec $_{1}$ & 0.546 & $3.00 \mathrm{E}-04$ & 0.428 \\
\hline & & Hambantota (DZ, IZ) & $\mathrm{Y}=6.723+0.001 \mathrm{EXC}_{3}-0.01 \mathrm{TWR}-0.007$ Prec $_{1}$ & 0.507 & 0.0017 & 0.362 \\
\hline & & Kurunegala (IZ, DZ) & $\mathrm{Y}=-14.851+0.041 \mathrm{ETA}_{3}+0.025 \mathrm{ETA}_{2}$ & 0.504 & $7.00 \mathrm{E}-04$ & 0.41 \\
\hline & & Batticaloa (DZ) & $Y=-9.58+0.03$ Prec $_{1}+0.014$ ETA $_{t}$ & 0.49 & $9.00 \mathrm{E}-04$ & 0.383 \\
\hline & & Badulla $(I Z, D Z)$ & $Y=0.437-0.002 \mathrm{EXC}_{4}-0.002 \mathrm{EXC}_{2}+0.007 \mathrm{DEF}_{1}$ & 0.49 & 0.0022 & 0.28 \\
\hline & & Anuradhapura & $\mathrm{Y}=12.462-0.015 \mathrm{DEF}_{3}-0.358 \mathrm{Tmax}_{2}-0.004 \mathrm{Prec}_{\mathrm{t}}$ & 0.423 & 0.006 & 0.117 \\
\hline & & Kilinochchi (DZ)* & $Y=-16.025+0.494 \operatorname{Tmax}_{2}$ & 0.177 & 0.0663 & 0.082 \\
\hline & \multirow{7}{*}{ 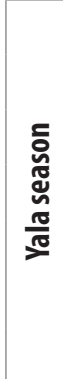 } & Ampara $(\mathbf{I Z}, \mathrm{DZ})$ & $Y=-1.933+0.02$ Prec $_{3}+0.002$ DEF $_{1}+0.002$ TWR & 0.408 & 0.0045 & 0.246 \\
\hline & & Polonnaruwa (DZ) & $\mathrm{Y}=-8.449-0.004 \mathrm{DEF}_{2}+0.306 \mathrm{Tmax}_{2}-0.011 \mathrm{ETA}_{4}$ & 0.304 & 0.0193 & 0.175 \\
\hline & & Batticaloa (DZ) & $\mathrm{Y}=-2.79+0.188 \mathrm{Tmin}_{4}-0.008 \mathrm{DEF}_{4}$ & 0.361 & 0.0043 & 0.298 \\
\hline & & Kurunegala (IZ, DZ) & $Y=-5.365+0.024 \mathrm{ETA}_{2}-0.001 \mathrm{EXC}_{\mathrm{t}}$ & 0.25 & 0.0217 & 0.159 \\
\hline & & Trincomalee (DZ)* & $Y=3.784-0.11 \operatorname{Tmax}_{3}$ & 0.17 & 0.0504 & 0.085 \\
\hline & & Hambantota $(\mathrm{DZ}, \mathrm{IZ})^{*}$ & $Y=3.525-0.005$ TWR & 0.041 & 0.1771 & 0.001 \\
\hline & & Anuradhapura (DZ)* & NA & NA & NA & NA \\
\hline
\end{tabular}

Notes: DZ - dry zone; IZ - intermediate zone; WZ - wet zone.

* indicates that the $\mathrm{R}_{\text {adj }}^{2}$ of the yield function falls below 0.2 , or the stepwise selection does not meet minimum quality criteria (high number of missing or repeated values in predictors). In these cases, the yield function is not considered for future projections.

\section{Maize}

For maize in the Maha season (supplementary irrigation), the climate variables (average maximum and minimum temperature and precipitation) appear as frequently as the water balance parameters (Table 8). Most of the time, maximum and minimum temperatures have negative coefficients, representing a negative impact of both day and night temperatures on yields. The precipitation appears with both negative and positive coefficients in DZ and IZ districts. Among water balance parameters, actual evapotranspiration is a common predictor in the various phases, usually with negative coefficients.

Water satisfaction index (WSI) and water excess $\left(\mathrm{EXC}_{\mathrm{i}}\right)$ appear with a positive impact, suggesting that maize, which has a high water requirement, can benefit most from water surplus (possibly stored in the soil), but suffer from water shortage. 
Table 8. Yield functions for maize per season and district

\begin{tabular}{|c|c|c|c|c|c|}
\hline & District & Yield function & $\mathbf{R}_{\text {adj }}^{2}$ & $\mathrm{p}$-value & $\mathbf{R}_{c v}^{2}$ \\
\hline \multirow{10}{*}{ 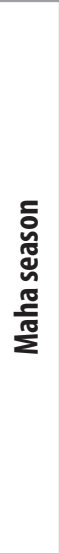 } & Anuradhapura (DZ) & $Y=-2.122+0.035$ WSI (corr) +0.039 ETA $_{2}-0.012$ TWR & 0.532 & 0.0011 & 0.398 \\
\hline & Moneragala $(\mathbf{I Z}, \mathrm{DZ})$ & $\mathrm{Y}=11.939-0.467 \mathrm{Tmin}_{2}+0.008$ Prec $_{3}-0.026 \mathrm{ETA}_{4}$ & 0.478 & 0.0026 & 0.334 \\
\hline & Kurunegala $(I Z, D Z)$ & $\mathrm{Y}=32.602+0.167 \mathrm{ETA}_{4}-0.078 \mathrm{ETA}_{2}-0.983 \operatorname{Tmax}_{2}$ & 0.428 & 0.0073 & 0.344 \\
\hline & Badulla $(\mathrm{IZ}, \mathrm{DZ})$ & $\mathrm{Y}=15.376-0.403 \operatorname{Tmax}_{3}+0.001 \mathrm{EXC}_{3}-0.115 \operatorname{Tmax}_{1}$ & 0.422 & 0.0061 & 0.264 \\
\hline & Polonnaruwa (DZ) & $\mathrm{Y}=3.868-0.039 \mathrm{ETA}_{4}-0.001 \mathrm{EXC}_{2}$ & 0.369 & 0.0061 & 0.301 \\
\hline & Batticaloa (DZ) & $Y=7.315+0.246 \operatorname{Tmin}_{2}-0.007$ Prec $_{t}-0.39 \operatorname{Tmax}_{3}$ & 0.31 & 0.0253 & 0.168 \\
\hline & Puttalam (DZ) & $Y=-11.745+0.527 \operatorname{Tmax}_{2}-0.248 \operatorname{Tmin}_{3}$ & 0.215 & 0.0439 & 0.103 \\
\hline & Hambantota (DZ,IZ) & $\mathrm{Y}=9.805+0.007 \mathrm{Prec}_{3}-0.3 \mathrm{Tmin}_{2}-0.017 \mathrm{ETA}_{2}$ & 0.214 & 0.0704 & 0.043 \\
\hline & Trincomalee (DZ)* & $\mathrm{Y}=4.717+0.342 \operatorname{Tmin}_{3}-0.358 \operatorname{Tmax}_{2}$ & 0.171 & 0.0713 & 0.02 \\
\hline & Ampara $(\mathrm{IZ}, \mathrm{DZ})^{*}$ & $Y=1.322-0.019$ Prec $_{t}$ & 0.151 & 0.0458 & 0.061 \\
\hline \multirow{5}{*}{$\frac{\pi}{\mathbb{N}}$} & Moneragala (IZ, DZ) & $\mathrm{Y}=18.278-0.037 \mathrm{ETA}_{2}-0.367 \mathrm{Tmin}_{2}-0.017 \mathrm{WSI}$ (corr) & 0.589 & $2.00 \mathrm{E}^{-04}$ & 0.499 \\
\hline & Badulla $(\mathbf{I Z}, \mathrm{DZ})$ & $Y=26.944-0.024 E_{E T}-0.522 \operatorname{Tmin}_{2}$ & 0.491 & $5.00 \mathrm{E}^{-04}$ & 0.345 \\
\hline & Polonnaruwa (DZ) & $Y=-19.767+0.838 \operatorname{Tmin}_{3}+0.008 \mathrm{EXC}_{t}$ & 0.407 & 0.0021 & 0.193 \\
\hline & Kurunegala $(\mathrm{IZ}, \mathrm{DZ})$ & $\mathrm{Y}=-10.726+0.438 \mathrm{Tmax}_{4}-0.003 \mathrm{DEF}_{3}-0.009 \mathrm{ETA}_{3}$ & 0.353 & 0.0101 & 0.184 \\
\hline & Anuradhapura (DZ)* & $\mathrm{Y}=3.273-0.007$ Prec $_{1}-0.005 \mathrm{ETA}_{\mathrm{t}}$ & 0.146 & 0.0794 & 0.057 \\
\hline
\end{tabular}

Notes: DZ - dry zone; IZ - intermediate zone; WZ - wet zone.

${ }^{*}$ indicates that the $\mathrm{R}^{2}$ ad of the yield function falls below 0.2 , or the stepwise selection does not meet minimum quality criteria (high number of missing or repeated values in predictors).

In these cases, the yield function is not considered for future projections.

During the Yala season (irrigated regime), yield in the districts of Badulla and Moneragala showed negative coefficients for minimum temperature, while Polonnaruwa and Kurunegala presented positive coefficients for $\operatorname{Tmin}_{3}$ and $\operatorname{Tmax}_{4}$, respectively. Evapotranspiration is also a common predictor in the Yala season, with negative coefficients, most likely due to unsatisfied water demand and plant stress.

\section{Big onion}

Big onion is cultivated mostly during the Yala season (supplementary irrigation). Maximum and minimum temperatures appear in all the yield functions with large and positive coefficients (Table 9). Big onion is indeed a crop that benefits from heat and high insolation, associated with high temperatures, and the Yala season is the most favourable season for its growth. Precipitation in the third stage of the crop appears with a positive coefficient in Polonnaruwa, while in Anuradhapura, precipitation during the early stage of the crop has a negative effect on yield, probably resulting in yield losses due to waterlogging.

Table 9. Yield functions for big onion per season and district

\begin{tabular}{|c|c|c|c|c|c|}
\hline & District & Yield function & $\mathbf{R}_{\text {adj }}^{2}$ & p-value & $\mathbf{R}_{\mathrm{c}}^{2}$ \\
\hline \multirow{4}{*}{$\frac{\pi}{\pi}$} & Polonnaruwa (DZ) & $Y=-34.545+0.017 \mathrm{DEF}_{\mathrm{t}}+0.219 \mathrm{Prec}_{3}+0.873 \mathrm{Tmin}_{1}$ & 0.413 & 0.0042 & 0.328 \\
\hline & Anuradhapura (DZ) & $\mathrm{Y}=-119.707+4.783 \mathrm{Tmin}_{\mathrm{t}}-0.071$ Prec $_{1}+0.018 \mathrm{ETA}_{\mathrm{t}}$ & 0.371 & 0.0078 & 0.226 \\
\hline & Matale $(\mathrm{IZ}, \mathrm{DZ})$ & $\mathrm{Y}=-57.486+0.063 \mathrm{EXC}_{1}+1.599 \operatorname{Tmax}_{2}$ & 0.323 & 0.0078 & 0.244 \\
\hline & Kurunegala $(\mathrm{IZ}, \mathrm{DZ})^{*}$ & NA & NA & NA & NA \\
\hline
\end{tabular}

Notes: DZ - dry zone; IZ - intermediate zone; WZ - wet zone.

* indicates that the $\mathrm{R}_{\text {adj }}$ of the yield function falls below 0.2 , or the stepwise selection does not meet minimum quality criteria (high number of missing or repeated values in predictors).

In these cases, the yield function is not considered for future projections. 


\section{Green gram}

For the Maha season (irrigated regime), the climate variables (precipitation and average maximum and minimum temperature) appear slightly less frequently than the water balance parameters as predictors (Table 10). Minimum and maximum temperatures most of the time show a negative relationship with yield. During the Yala season (irrigated regime), water balance parameters appear as climate variables, with minimum temperature having negative and positive coefficients for Moneragala and Kurunegala, respectively. Overall, for both the Maha and Yala seasons, relevant predictors are the temperatures, with increase having a negative impact on yield.

Table 10. Yield functions for green gram per season and district

\begin{tabular}{|c|c|c|c|c|c|}
\hline & District & Yield function & $\mathbf{R}_{\text {adj }}^{2}$ & p-value & $\mathbf{R}_{\mathrm{cv}}^{2}$ \\
\hline \multirow{6}{*}{ 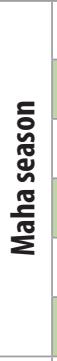 } & Puttalam (DZ) & $Y=6.177-0.276 \operatorname{Tmin}_{2}-0.002 \operatorname{Prec}_{3}+0.001 \mathrm{DEF}_{t}$ & 0.505 & 0.0017 & 0.396 \\
\hline & Ampara (IZ, DZ) & $\mathrm{Y}=1.296+0.004 \mathrm{Prec}_{3}+0.001 \mathrm{EXC}_{3}-0.014 \mathrm{ETA}_{4}$ & 0.49 & 0.0022 & 0.22 \\
\hline & Hambantota (DZ, IZ) & $Y=6.117-0.013 \mathrm{ETA}_{3}-0.003 \mathrm{DEF}_{1}-0.089 \operatorname{Tmax}_{4}$ & 0.481 & 0.0026 & 0.382 \\
\hline & Moneragala (IZ, DZ) & $Y=2.792-0.234 \operatorname{Tmin}_{2}+0.063 \operatorname{Tmax}_{1}+0.002 \mathrm{DEF}_{4}$ & 0.475 & 0.0028 & 0.277 \\
\hline & Anuradhapura (DZ) & $\mathrm{Y}=-2.774+0.003 \mathrm{WSI}$ (corr) $+0.014 \mathrm{ETA}_{2}+0.002 \mathrm{DEF}_{4}$ & 0.47 & 0.003 & 0.321 \\
\hline & Kurunegala (IZ, DZ) & $Y=-0.074-0.005 \mathrm{DEF}_{2}+0.002$ Prec $_{1}$ & 0.256 & 0.027 & 0.169 \\
\hline \multirow{3}{*}{ 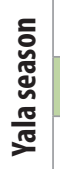 } & Moneragala (IZ, DZ) & $Y=1.093+0.002 \mathrm{EXC}_{1}+0.005 \mathrm{ETA}_{3}-0.098 \mathrm{Tmin}_{2}$ & 0.423 & 0.0036 & 0.207 \\
\hline & Kurunegala $(\mathbf{I Z , D Z})$ & $\mathrm{Y}=-3.759+0.158 \mathrm{Tmin}_{1}+0.016 \mathrm{Prec}_{3}-0.001 \mathrm{EXC}_{2}$ & 0.421 & 0.0037 & 0.224 \\
\hline & Hambantota (DZ, IZ)* & $Y=0.219-0.001 \mathrm{DEF}_{\mathrm{t}}$ & 0.087 & 0.0936 & 0.025 \\
\hline
\end{tabular}

Notes: DZ - dry zone; IZ - intermediate zone; WZ - wet zone.

${ }^{*}$ indicates that the $\mathrm{R}^{2}$ adj of the yield function falls below 0.2 , or the stepwise selection does not meet minimum quality criteria (high number of missing or repeated values in predictors). In these cases, the yield function is not considered for future projections.

\section{Potato}

For the Maha season (irrigated regime), the minimum temperature appears with positive and negative coefficients in Jaffna and Nuwara Eliya, respectively, and the maximum temperature in the third phase appears with a positive coefficient in Nuwara Eliya (Table 11). During the Yala season (irrigated regime), water balance predictors are more common than during the Maha season. Water deficit appears with a negative coefficient in the second phase and with a positive coefficient in the fourth phase, most likely because dry conditions are more suitable for maturity.

Table 11. Yield functions for potato per season and district

\begin{tabular}{|c|c|c|c|c|c|}
\hline & District & Yield function & $\mathbf{R}_{\text {adj }}^{2}$ & p-value & $\mathbf{R}_{\mathrm{c}}^{2}$ \\
\hline \multirow{3}{*}{$\frac{\frac{\pi}{0}}{\sum_{0}^{\pi}}$} & Jaffna (DZ) & $Y=-43.093-0.009 \mathrm{EXC}_{3}+2.065 \mathrm{Tmin}_{\mathrm{t}}$ & 0.415 & 0.0031 & 0.169 \\
\hline & Nuwara Eliya (WZ, IZ) & $\mathrm{Y}=-8.771-0.746 \operatorname{Tmin}_{1}-0.2 \mathrm{DEF}_{2}+0.806 \operatorname{Tmax}_{3}$ & 0.203 & 0.0785 & 0.049 \\
\hline & Badulla (IZ)* & $Y=-0.795+0.006 \operatorname{EXC}_{2}$ & 0.161 & 0.0404 & 0.043 \\
\hline \multirow{2}{*}{$\frac{\pi}{\frac{\pi}{\pi}}$} & Nuwara Eliya (WZ, IZ) & $\mathrm{Y}=5.348-0.024 \mathrm{ETA}_{3}-0.033 \mathrm{DEF}_{2}+0.012 \mathrm{Prec}_{3}$ & 0.53 & $5.00 \mathrm{E}-04$ & 0.415 \\
\hline & Badulla (IZ) & $\mathrm{Y}=-1.389-0.033 \mathrm{Prec}_{2}+0.026 \mathrm{DEF}_{4}+0.024 \mathrm{EXC}_{1}$ & 0.469 & 0.0017 & 0.264 \\
\hline
\end{tabular}

Notes: DZ - dry zone; IZ - intermediate zone; WZ - wet zone.

${ }^{*}$ indicates that the $\mathrm{R}^{2}$ ad of the yield function falls below 0.2 , or the stepwise selection does not meet minimum quality criteria (high number of missing or repeated values in predictors). In these cases, the yield function is not considered for future projections. 


\section{Chilli}

For the Maha season (irrigated regime), maximum and minimum temperatures in different phases of the growing period have negative impacts in Ampara, Anuradhapura and Badulla, while Tmin appears with a positive coefficient in Jaffna (Table 12). Water deficit, in the different growing stages, appears with negative coefficients (four times), while in Moneragala it appears with a positive coefficient. During the Yala season (irrigated regime), minimum and maximum temperatures and water excess are the most frequent predictors. Both maximum and minimum temperatures have negative impacts in most districts. Maximum and minimum temperatures are also common predictors (Maha and Yala seasons), generally presenting negative coefficients ( 6 out of 8 cases for Tmax, 4 out of 7 for Tmin). This suggests that in a climate change context, chillies are harmed by increased day and night temperatures.

Table 12. Yield functions for chilli per season and district

\begin{tabular}{|c|c|c|c|c|c|}
\hline & District & Yield function & $\mathbf{R}_{\text {adj }}^{2}$ & p-value & $\mathbf{R}_{\mathrm{cv}}^{2}$ \\
\hline \multirow{8}{*}{ 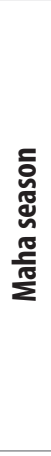 } & Ampara (IZ, DZ) & $\mathrm{Y}=15.682-0.01 \mathrm{DEF}_{1}-0.011 \mathrm{DEF}_{3}-0.487 \operatorname{Tmax}_{3}$ & 0.463 & 0.0033 & 0.345 \\
\hline & Anuradhapura (DZ) & $Y=9.667+0.02$ Prect $-0.005 \mathrm{EXC}_{4}-0.496 \mathrm{Tmin}_{2}$ & 0.46 & 0.0035 & 0.054 \\
\hline & Badulla (IZ) & $Y=3.301+0.001 \mathrm{EXC}_{3}-0.107 \operatorname{Tmax}_{1}-0.028 \mathrm{DEF}_{2}$ & 0.444 & 0.0044 & 0.322 \\
\hline & Jaffna (DZ) & $Y=-26.962+1.052 \operatorname{Tmin}_{t}+0.079 \mathrm{ETA}_{1}$ & 0.388 & 0.0047 & 0.047 \\
\hline & Hambantota (DZ, IZ) & $\mathrm{Y}=0.395-0.008 \mathrm{DEF}_{1}-0.003 \mathrm{EXC}_{1}-0.005 \mathrm{Prec}_{4}$ & 0.297 & 0.0293 & 0.199 \\
\hline & Moneragala (IZ, DZ) & $Y=-1.651+0.003 \mathrm{EXC}_{3}+0.021 \mathrm{DEF}_{1}$ & 0.281 & 0.02 & 0.032 \\
\hline & Puttalam (DZ)* & $Y=-1.427+0.031 \mathrm{Prec}_{3}$ & 0.17 & 0.036 & 0.009 \\
\hline & Kurunegala $(I Z, D Z)^{*}$ & $Y=-9.879+1.129 \operatorname{Tmax}_{1}-0.302 \mathrm{ETA}_{2}-0.008 \mathrm{EXC}_{1}$ & 0.148 & 0.1303 & 0.036 \\
\hline \multirow{7}{*}{ 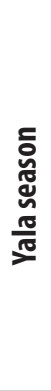 } & Badulla (IZ) & $Y=16.156-0.45 \operatorname{Tmin}_{t}-0.228 \operatorname{Tmax}_{2}-0.008 \mathrm{EXC}_{3}$ & 0.574 & $2.00 \mathrm{E}-04$ & 0.039 \\
\hline & Kurunegala (IZ, DZ) & $\mathrm{Y}=16.317+0.003 \mathrm{EXC}_{3}-0.713 \mathrm{Tmin}_{\mathrm{t}}-0.002 \mathrm{EXC}_{2}$ & 0.431 & 0.0031 & 0.192 \\
\hline & Hambantota (DZ, IZ) & $Y=24.743+0.013 \mathrm{EXC}_{3}-0.714 \operatorname{Tmax}_{1}-0.017 \mathrm{Prec}_{1}$ & 0.414 & 0.0041 & 0.121 \\
\hline & Matale (IZ, DZ) & $Y=7.058-0.037$ WSI (corr) $-0.184 \operatorname{Tmin} 1$ & 0.375 & 0.0035 & 0.25 \\
\hline & Anuradhapura (DZ) & $Y=6.528+0.005 \mathrm{EXC}_{1}-0.399 \operatorname{Tmax}_{4}+0.314 \operatorname{Tmin}_{3}$ & 0.308 & 0.0184 & 0.228 \\
\hline & Puttalam (DZ) & $Y=-6.186+0.757 \operatorname{Tmin}_{1}-0.31 \operatorname{Tmax}_{1}$ & 0.254 & 0.0205 & 0.191 \\
\hline & Jaffna (DZ)* & $Y=8.667-0.266 \operatorname{Tmax}_{4}+0.015 \mathrm{DEF}_{2}$ & 0.137 & 0.0878 & 0.019 \\
\hline
\end{tabular}

Notes: DZ - dry zone; IZ - intermediate zone; WZ - wet zone.

* indicates that the $\mathrm{R}_{\text {adj }}$ of the yield function falls below 0.2 , or the stepwise selection does not meet minimum quality criteria (high number of missing or repeated values in predictors).

In these cases, the yield function is not considered for future projections.

\subsection{Projected future yield changes}

Using the regression models obtained in the previous section, which take into account climate and water balance variables, the projected yield changes are estimated by running the WABAL model with the GCM downscaled data, which have been interpolated with AURHELY at a dekadal time resolution. Climate downscaled variables (Tmax, Tmin, Prec) are averaged over the four growing stages that are considered for the water balance parameters. The predictors identified in the previous section are thus calculated with the simulated climate data for both historical (1970-2000) and future periods (middle future [2040-2069]; far future [2070-2099]), to evaluate the projected yield changes with the yield functions. 
The projected yield changes are presented in Figures 10-35 for all crops, with climate data derived from GCMs and relative to both future periods and scenarios. Undefined yield functions ("NA" in Tables 7-12) or yield functions with $\mathrm{R}^{2}<0.2$ are not used for the projection and therefore yield changes corresponding to these do not appear in the maps.

To quantify the significance of the future-historical difference, an equivalence test (similar to the $\mathrm{t}$-test) is performed, where the difference between future and past mean values of anomaly are compared, in absolute value, to a certain threshold (Wellek, 2010). The threshold is set to the standard deviation of the historical anomaly $\left(\mathrm{SD}_{\text {hist }}\right)$, considered as the characteristic fluctuation of the yield, and to twice this standard deviation.

Thus, if the difference between the average modelled future anomaly and modelled historical anomaly is larger than this threshold (at the 5 percent significance level), the yield change is considered "significant", otherwise considered to be within the inherent variability of the historical yields. If the future-historical difference is twice the $\mathrm{SD}_{\text {hist }}$ (at the 5 percent significance level), the change is considered "very significant". The significant and very significant cases are represented with an overlay of vertical lines and cross-hatch, respectively, in Figures 10-35.

Conceptually, the future yield change assessment is based on the following assumption. As climate changes, water balance conditions also change. Climate affects crops in many ways, and the variation of water balance conditions is one of the most important, in addition to the changes in climate itself. Both historical and future yields are modelled by replacing the values of the predictors appearing in the yield function (see Tables 7-12) with the values derived from GCMs. This evaluation is done separately for each crop, district, season and irrigation mode. The disaggregated analysis allows to appreciate the impacts of climate change in different locations and under various conditions. 


\section{Growing season Maha (1 September to 20 February)}

To help interpret the yield changes in response to changes in climate and in water balance parameters, Figure 9 reports the projected changes for the selected climate variables (Tmax, Tmin, Prec) and the actual evapotranspiration of rice (ETa), averaged over the Maha growing season at the district level, from one climate model. While not the sole predictors used in the regression models, they provide some of the main features of climate change that are relevant for crops.

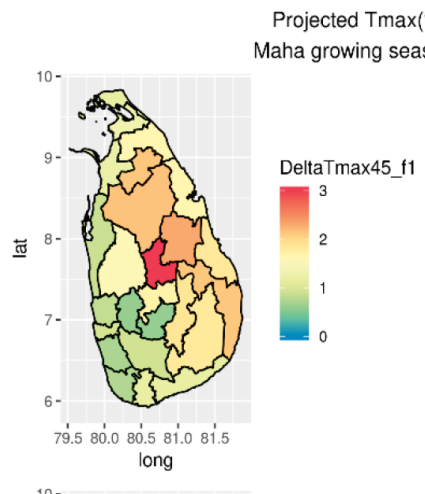

son - CANESM model
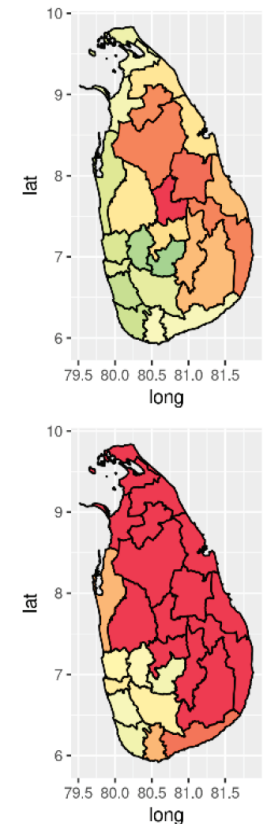

79.580 .080 .581 .081 .5

long

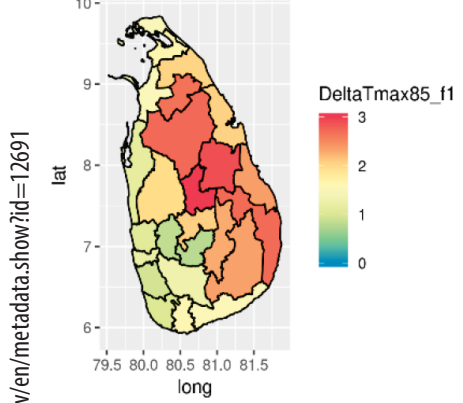

Projected Prec(mm/dek) change during Maha growing season - CANESM model

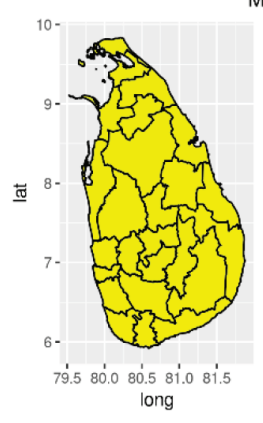

$$
10-
$$
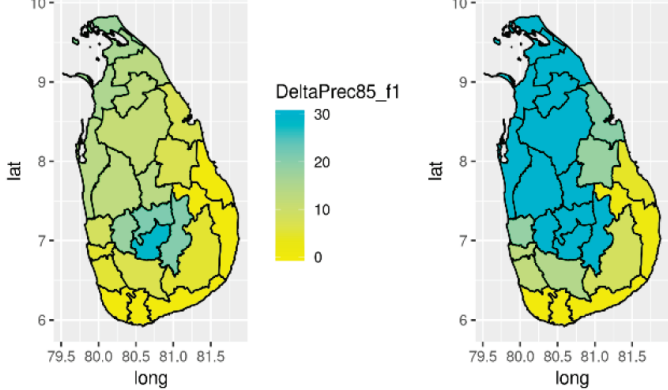
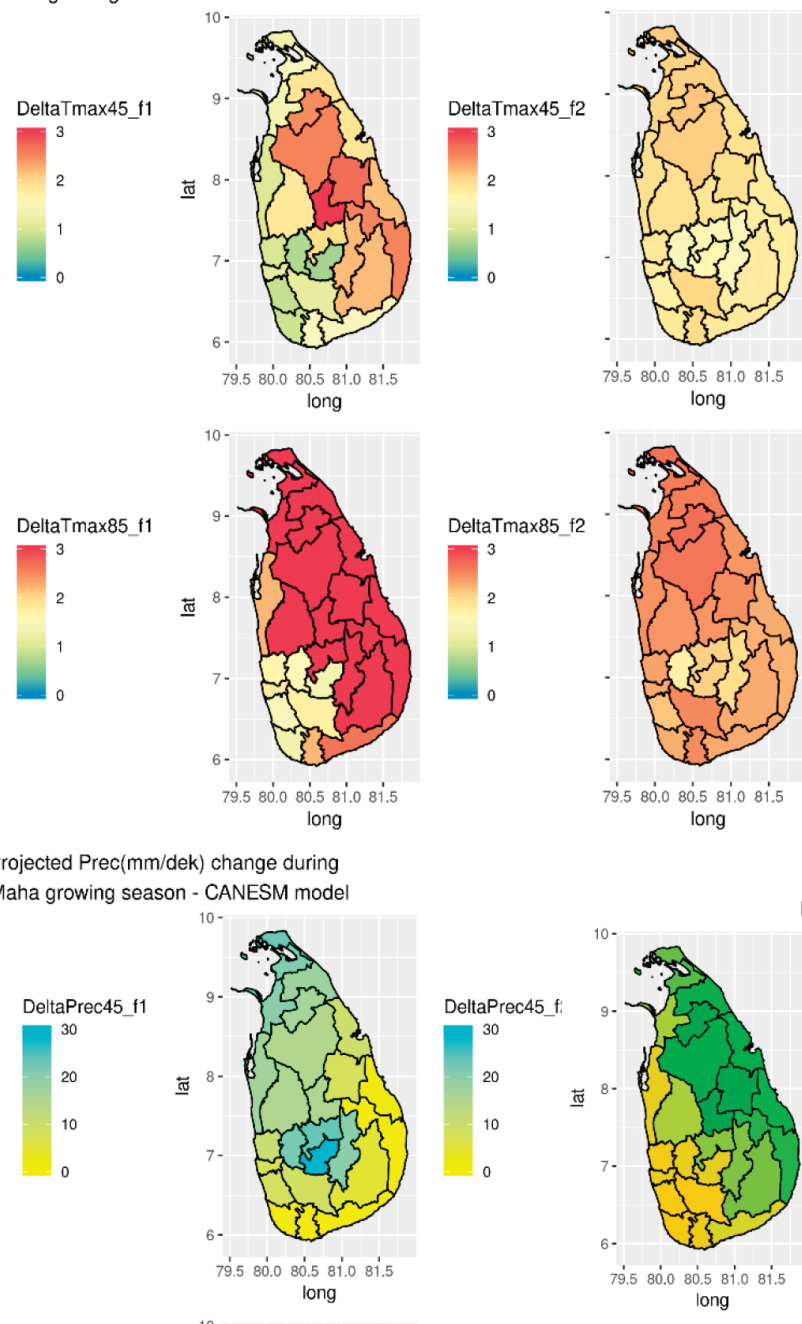

Projected $\operatorname{Tmin}\left({ }^{\circ} \mathrm{C}\right)$ change during

Maha growing season - CANESM model
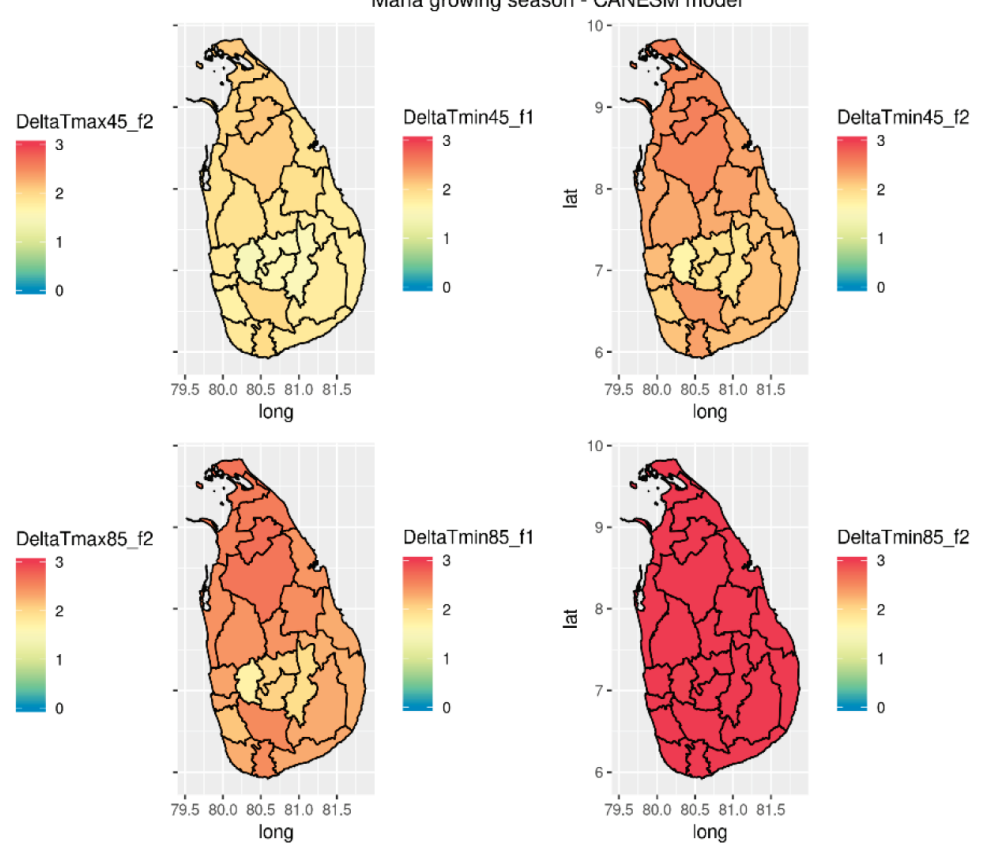

DeltaTmin85 $f 2$

Projected ETA(mm/dek) change during

Maha growing season - CANESM model
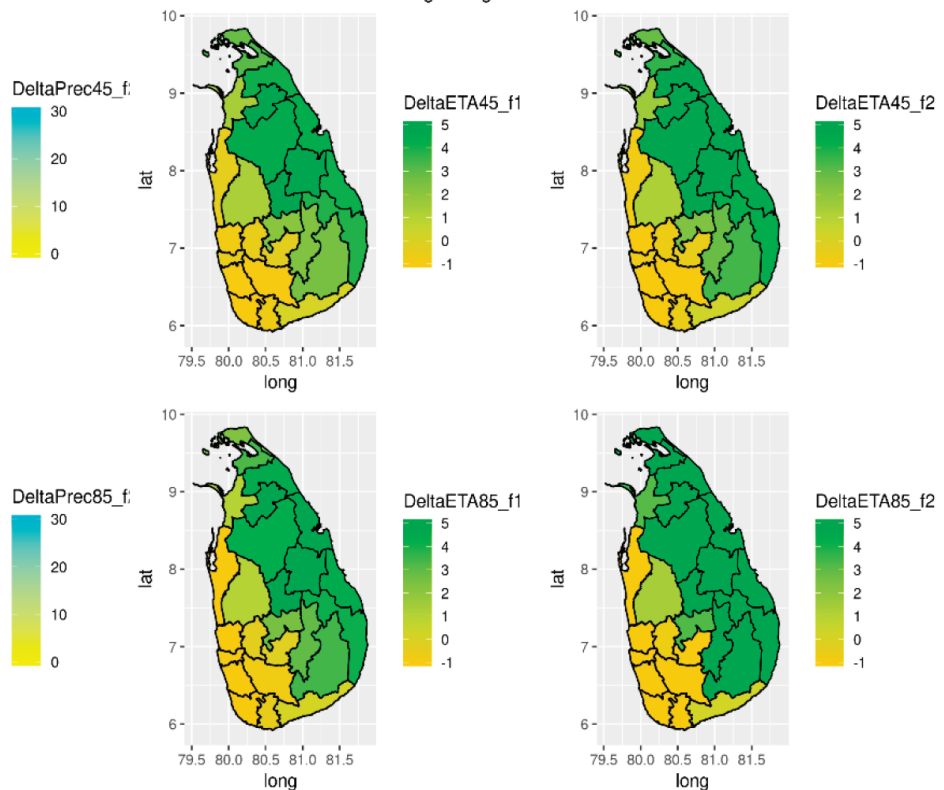

Figure 9. Projected changes in selected climate and water balance parameters averaged over the Maha growing season, according to the CanESM2 model 
In the modelling approach adopted, the start date and length of growing season are the same for all the crops, and the season averages of Tmax, Tmin and Prec are therefore the same for all the crops, while ETa changes according to the crop coefficients $\mathrm{Kc}_{\mathrm{i}}$.

Potential changes in future water availability for irrigation are not explicitly considered in the present modelling approach.

Both Tmax and Tmin are projected to increase by $0.5-3.0^{\circ} \mathrm{C}$ in both scenarios, both middle and far future, for all districts. The Tmax increase is higher in the central to eastern regions of the country, while Tmin is lower in the central and mountain regions. The increase in Tmin is generally higher than the increase in Tmax, resulting in a future decrease in night-day temperature excursion. This is particularly evident for the worst scenario (RCP8.5) and the far future (2070-2100). The Tmax increase shows a quite evident west-east gradient, with a higher increase in the east of the country. The Tmin increase, on the other hand, is more homogeneous.

Precipitation is projected to increase, especially in the central, hilly and mountain regions of the country. The projected increase is much more important for the worst scenario and far future, involving further increase also in the northern part of the country.

The actual evapotranspiration of rice during the Maha season is generally projected to increase, in line with Tmax, Tmin and precipitation changes, mostly in the central, western and northern parts of the country.

The projected changes are very similar in the Maha and Yala seasons, although slightly higher (in absolute value) for the Maha season (not shown). 


\section{Rice}

\section{Projected yield changes for rice, Maha season, rainfed regime}

Generally, in the Maha season and under the rainfed regime, climate change impacts are projected to be negative in the centre-north of the country and negligible or positive in the south. All the models, for both scenarios and future horizons, project a negative change in rice yields in the districts of Kurunegala and Anuradhapura, located in the dry zone. Figures 10-12 show negative climate change impacts for all the models, future horizons and scenarios. This can be attributed to the negative impacts of increasing precipitation, with a yield function containing negative coefficients for both $\mathrm{Prec}_{2}$ and $\mathrm{Prec}_{3}$ (Table 7). Anuradhapura is indeed located in the north-central lowlands, particularly prone to floods in the Maha season. The impact in Moneragala (DZ-IZ) and Kalutara (WZ) is positive for all the models (with yield functions containing positive relationships with $\operatorname{Tmin}_{2}$ and $\operatorname{Tmin}_{3}$, respectively).
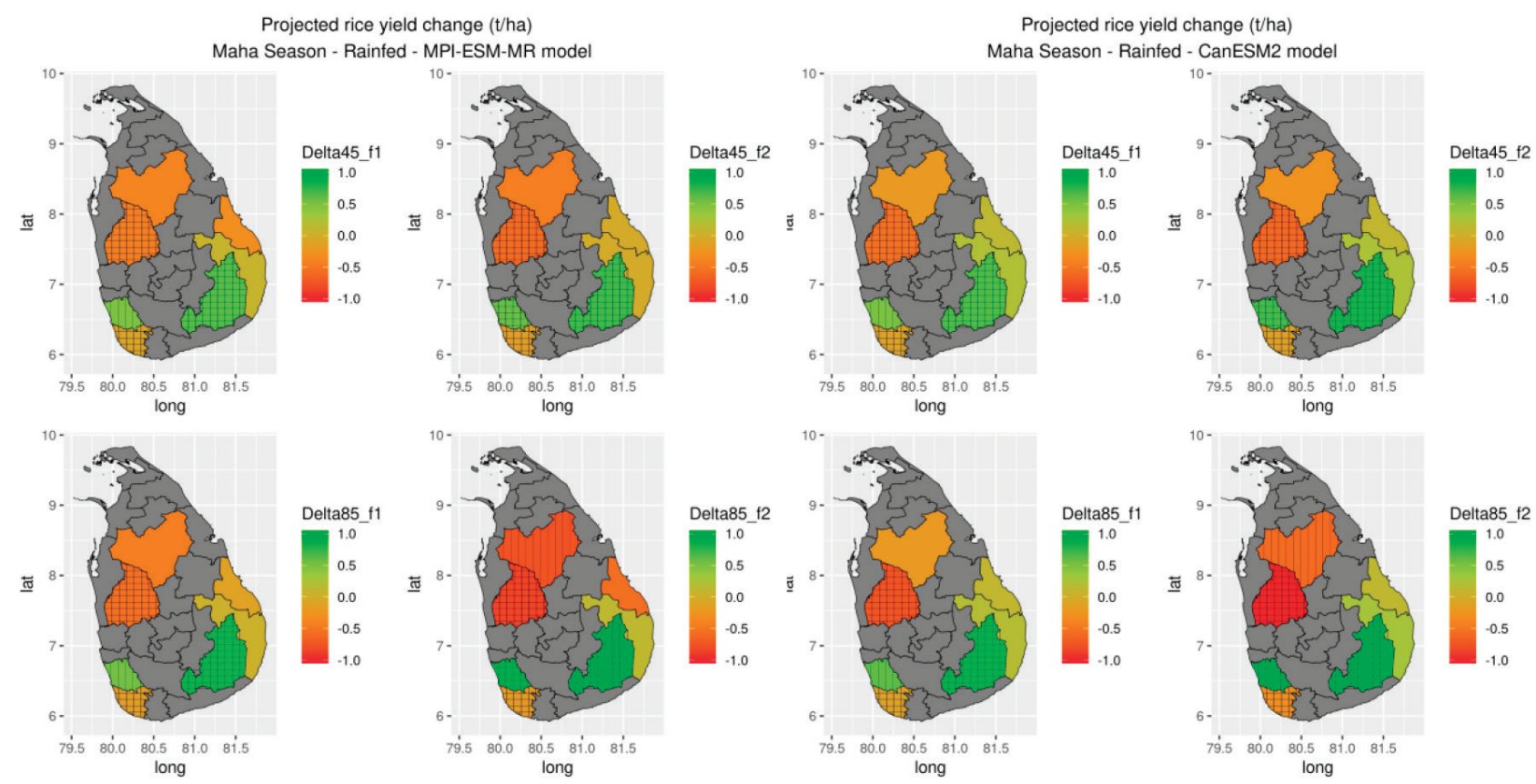

Source: UN. 2020. Map of the World [online]. [Cited 8 March 2021]. http://www.fao.org/geonetwork/srv/en/metadata.show?id=12691

Figure 10. Projected rice yield changes for the Maha season, rainfed regime, according to MPI-ESM-MR and CanESM2 climate models (tonnes/ha) 


\section{Projected yield changes for rice, Maha season, irrigated regime}

For the Maha season, under the irrigated regime, there is less agreement among models than for the Yala season. With the exception of the MIROC model, impacts are only slightly negative, or positive (Figures 13-15). Anuradhapura District appears negatively affected by climate change for all the models, to varying extent, generally more significantly for the far future and RCP8.5 scenario. The yield function of Anuradhapura is indeed dominated by negative dependency on $\mathrm{DEF}_{3}, \operatorname{Tmax}_{2}$ and $\operatorname{Prec}_{\mathrm{t}}$ (Table 7); therefore, projected predictors increase from all the GCM results in negative yield changes.
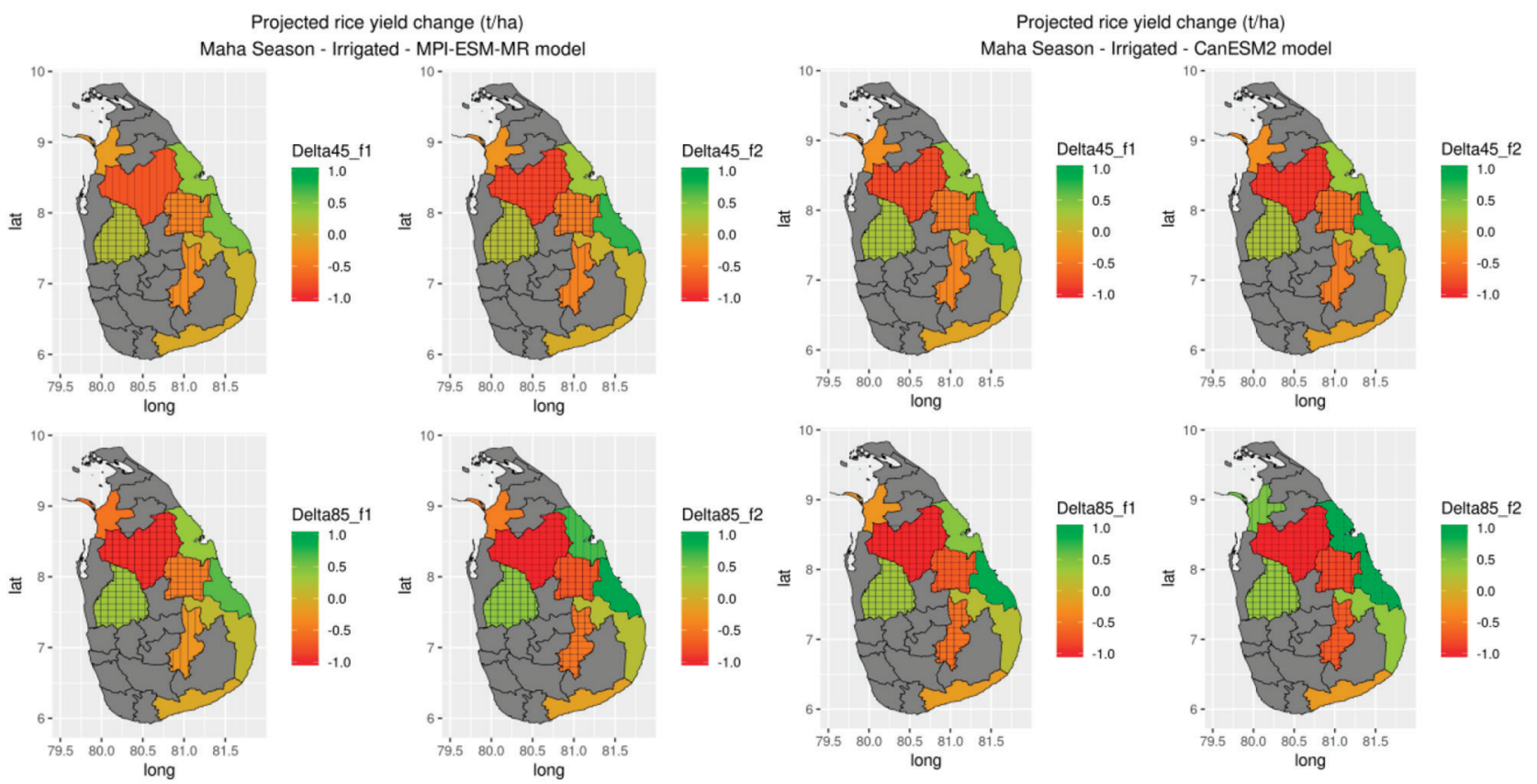

Source: UN. 2020. Map of the World [online]. [Cited 8 March 2021]. http://www.fao.org/geonetwork/srv/en/metadata.show?id=12691

Figure 13. Projected rice yield changes for the Maha season, irrigated regime, according to MPI-ESM-MR and CanESM2 climate models (tonnes/ha) 

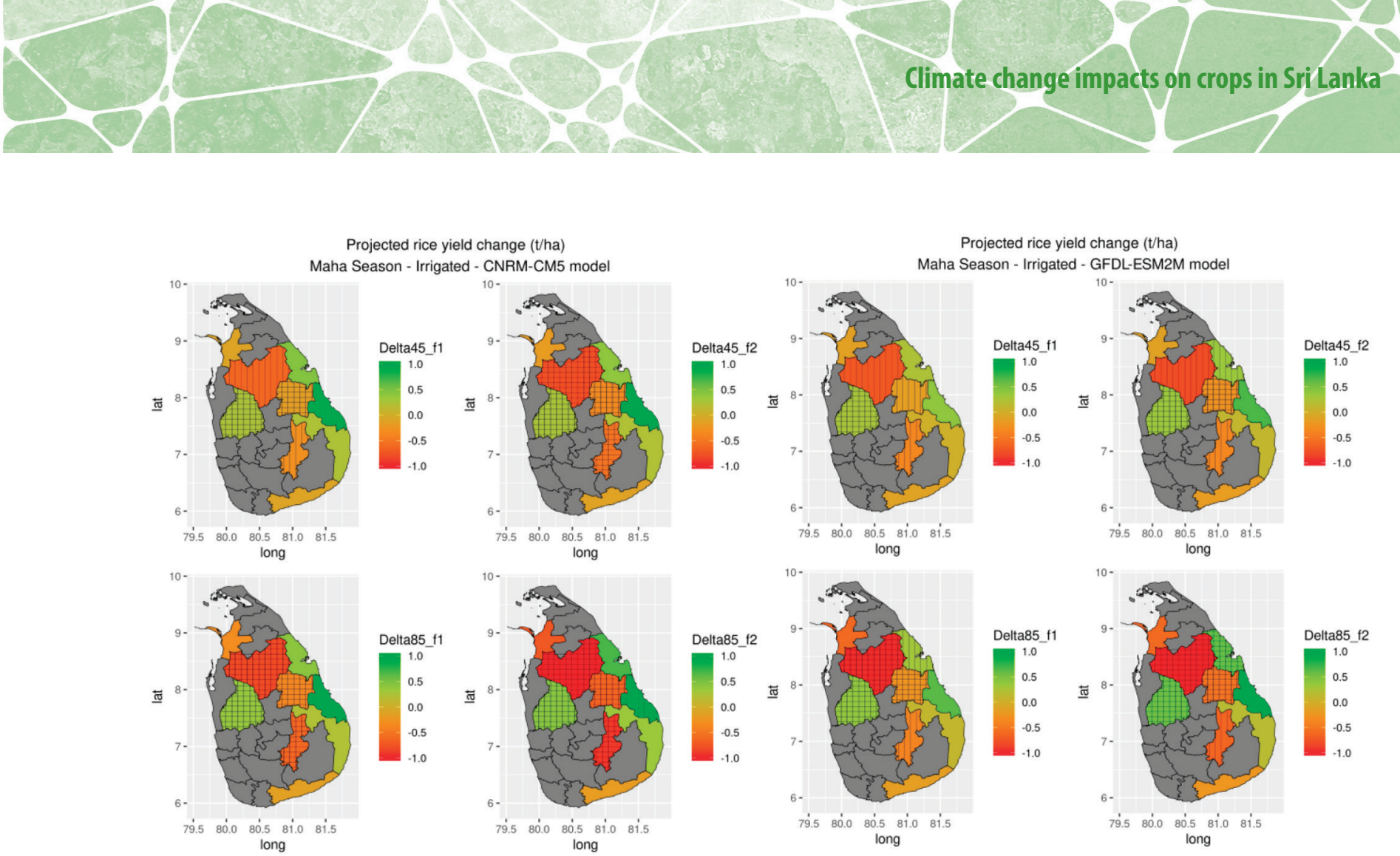

Source: UN. 2020. Map of the World [online]. [Cited 8 March 2021]. http://www.fao.org/geonetwork/srv/en/metadata.show?id=12691

Figure 14. Projected rice yield changes for the Maha season, irrigated regime, according to CNRM-CM5 and GFDL-ESM2M models (tonnes/ha)

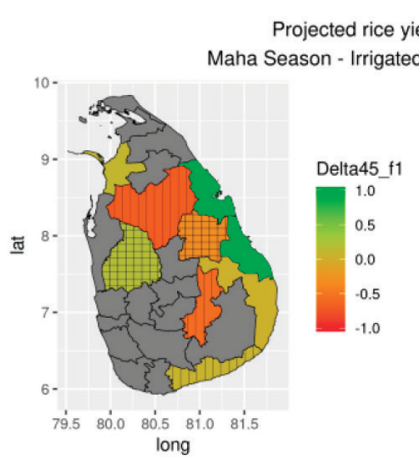

\section{d change (t/ha) \\ - IPSL-CM5A-MR model}
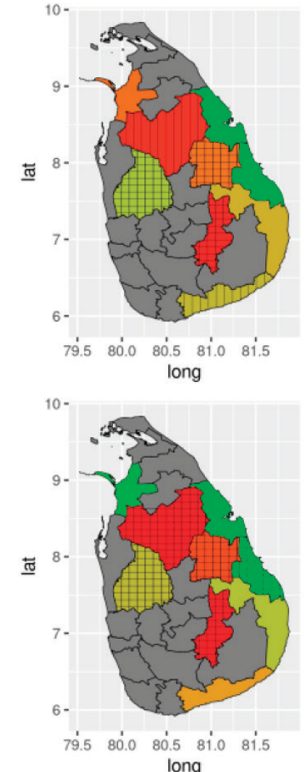
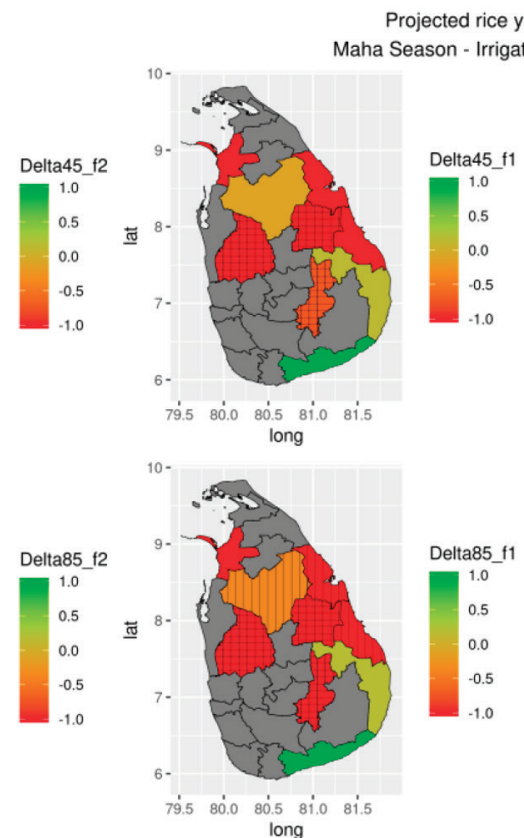

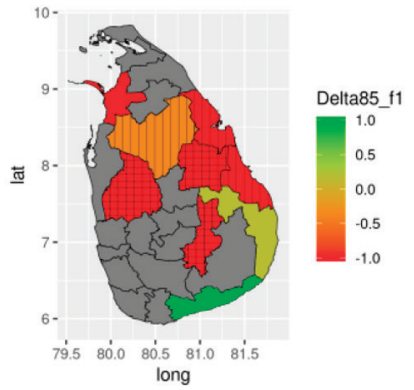

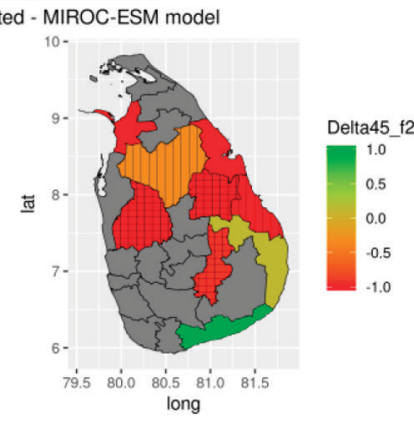

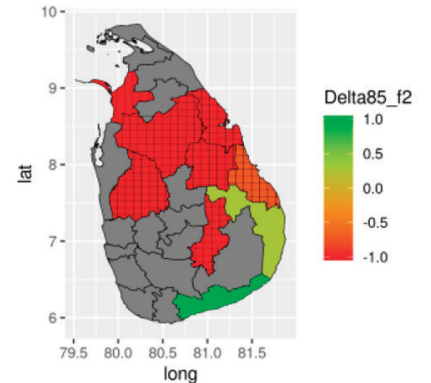

Source: UN. 2020. Map of the World [online]. [Cited 8 March 2021]. http://www.fao.org/geonetwork/srv/en/metadata.show?id=12691

Figure 15. Projected rice yield changes for the Maha season, irrigated regime,

according to IPSL-CM5A-MR and MIROC-ESM models (tonnes/ha) 


\section{Projected yield changes for rice, Yala season, irrigated regime}

For the Yala season, under the irrigated regime, the impacts are predominantly positive; they are negative only in Kurunegala District (Figures 16-18). This can be explained by the positive relationship with temperature (maximum/minimum) and precipitation in the yield functions of four districts in this season (Table 7), and the projected increased temperature. In Kurunegala District, the negative EXC coefficient leads to negative impact on yield in all projections.
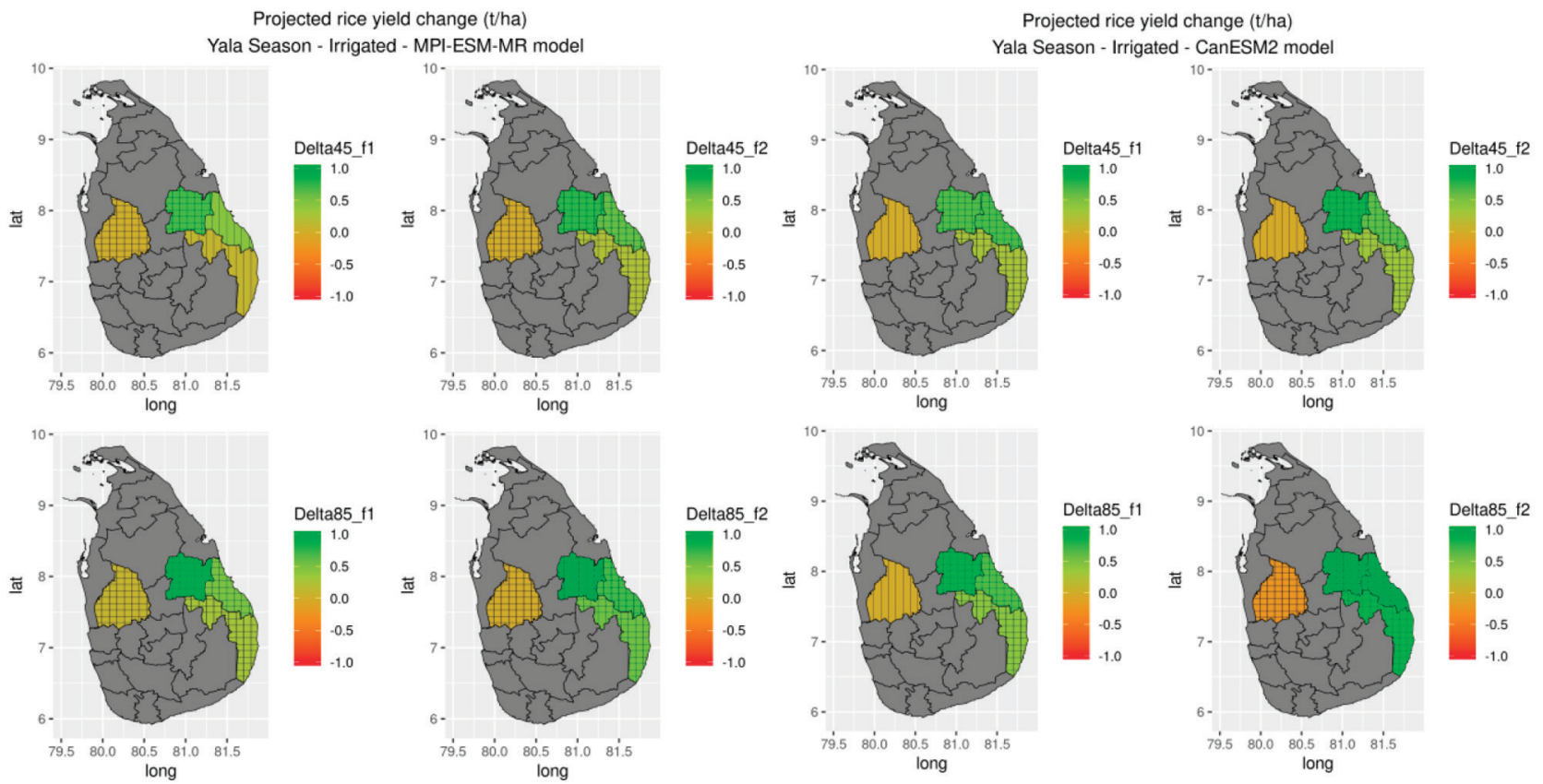

Source: UN. 2020. Map of the World [online]. [Cited 8 March 2021]. http://www.fao.org/geonetwork/srv/en/metadata.show?id=12691

Figure 16. Projected rice yield changes for the Yala season, irrigated regime, according to MPI-ESM-MR and CanESM2 climate models (tonnes/ha) 


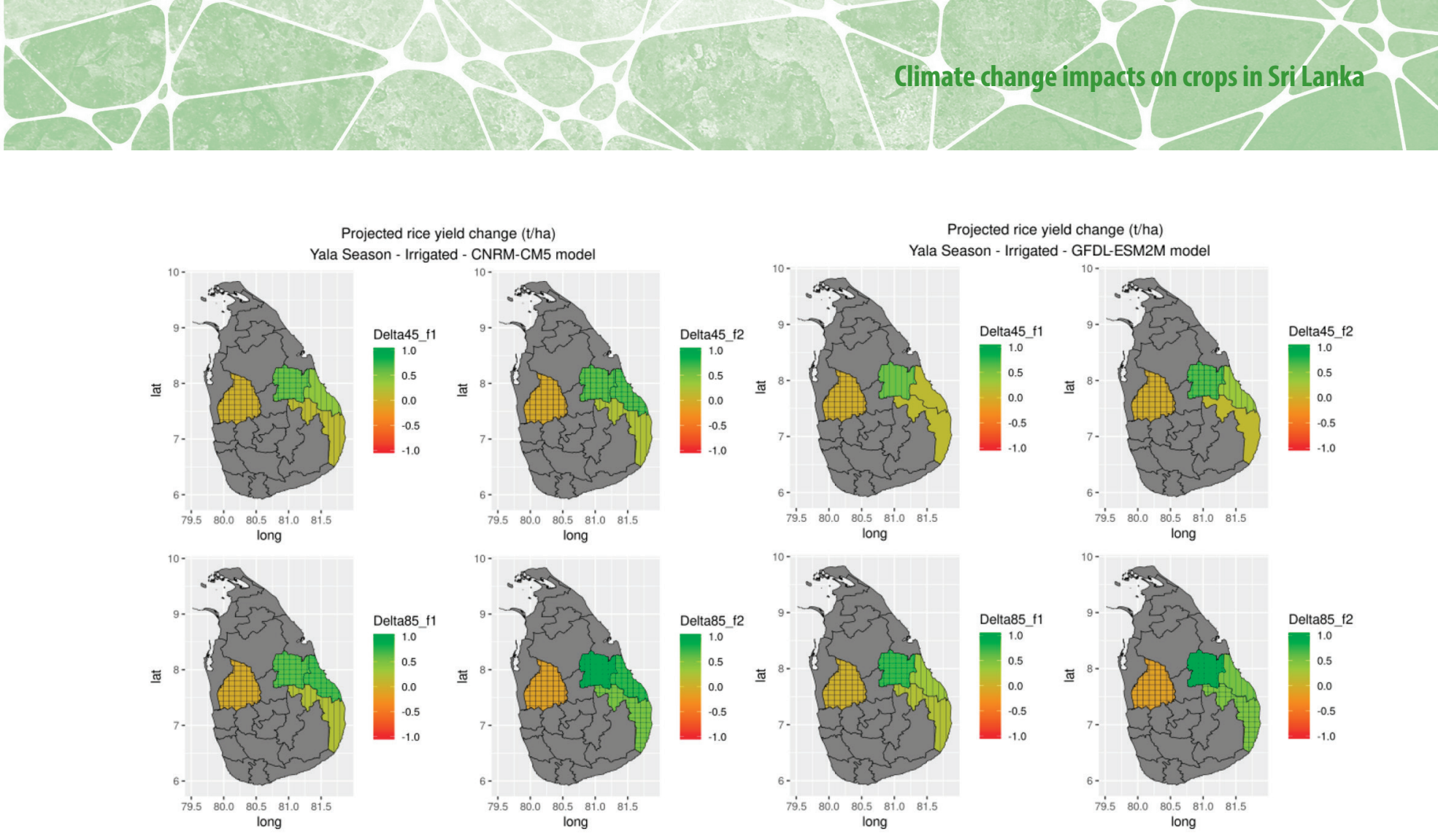

Source: UN. 2020. Map of the World [online]. [Cited 8 March 2021]. http://www.fao.org/geonetwork/srv/en/metadata.show?id=12691

Figure 17. Projected rice yield changes for the Yala season, irrigated regime,

according to CNRM-CM5 and GFDL-ESM2M models (tonnes/ha)

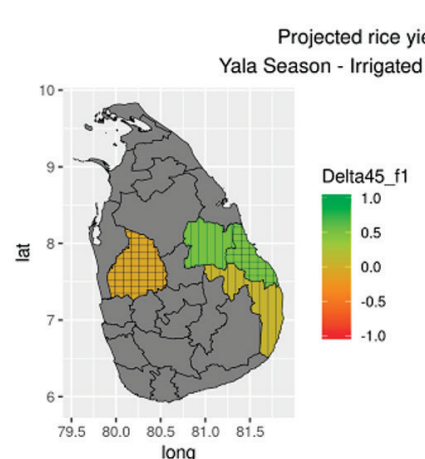

- IPSL-CM5A-MR model
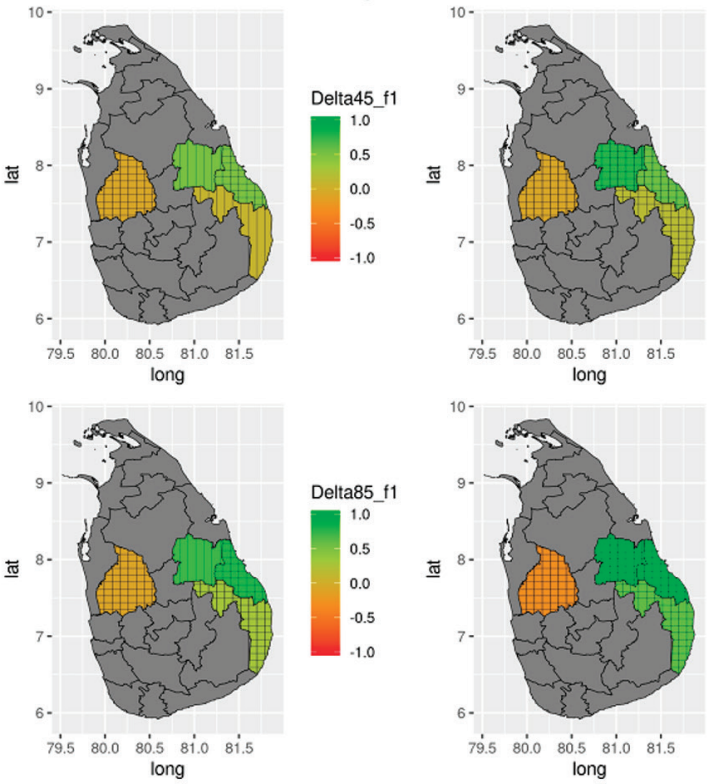
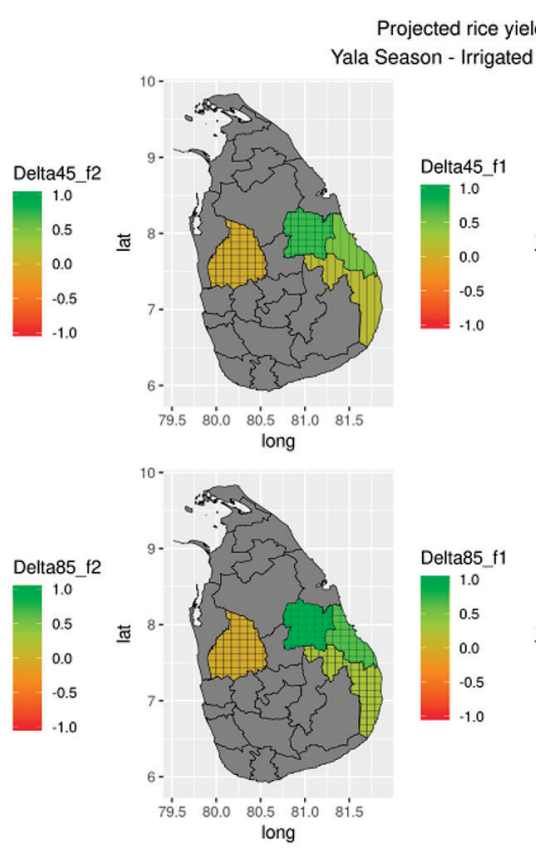
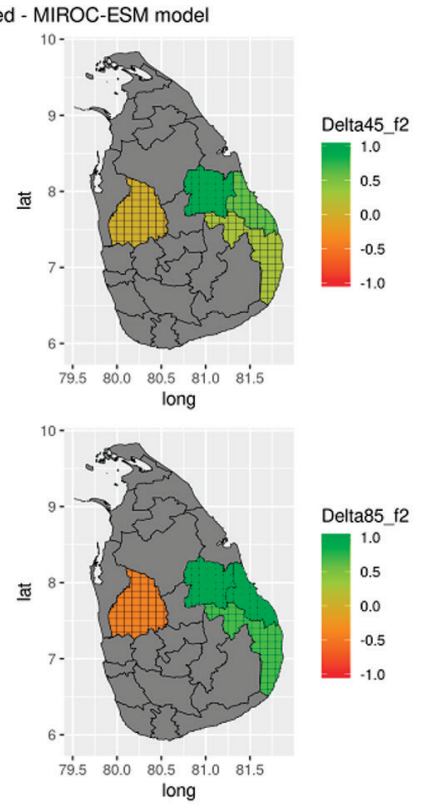

Source: UN. 2020. Map of the World [online]. [Cited 8 March 2021]. http://www.fao.org/geonetwork/srv/en/metadata.show?id=12691

Figure 18. Projected rice yield changes for the Yala season, irrigated regime, according to IPSL-CM5A-MR and MIROC-ESM models (tonnes/ha)

Notes: For each model in Figures 16-18, four maps are reported with projected changes for two RCPs (45 is RCP4.5; 85 is RCP8.5) and two future periods (f1 is middle future [2040-2069]; $\mathrm{f} 2$ is far future [2070-2100]). Vertical lines denote projected changes larger than the historical standard deviation of yield anomaly and cross-hatch those more than twice as large. 


\section{Maize}

\section{Projected yield changes for maize, Maha season}

All the models, for both scenarios and future horizons, project a negative change in maize yields in all districts (Figures 19-21). This can be attributed to the negative impacts of increasing temperatures and actual crop evapotranspiration. Most of the yield functions of maize indeed contained temperatures and ETa as negative predictors (Table 8).
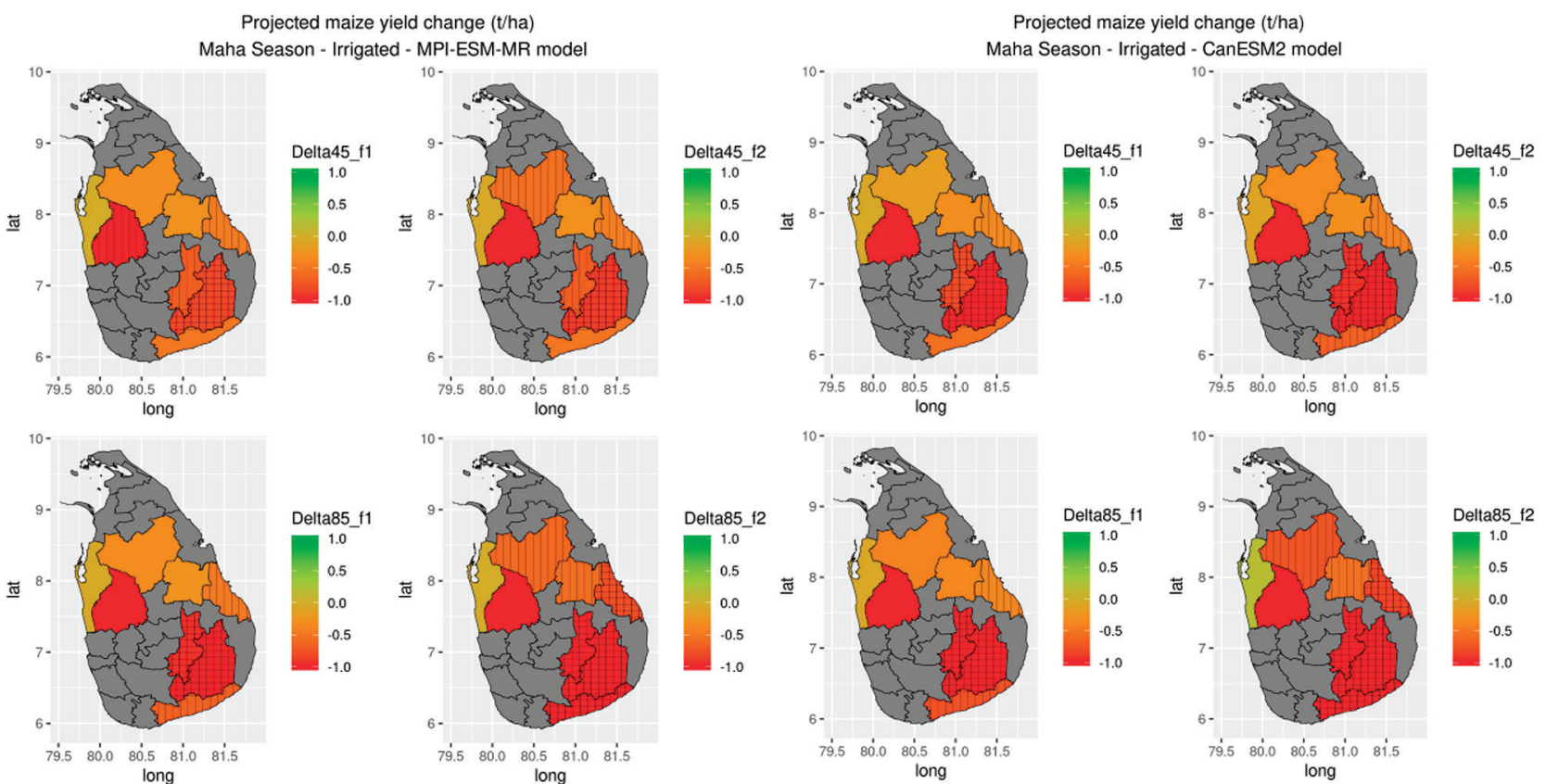

Source: UN. 2020. Map of the World [online]. [Cited 8 March 2021]. http://www.fao.org/geonetwork/srv/en/metadata.show?id=12691

Figure 19. Projected maize yield changes for the Maha season, irrigated regime, according to MPI-ESM-MR and CanESM2 climate models (tonnes/ha) 


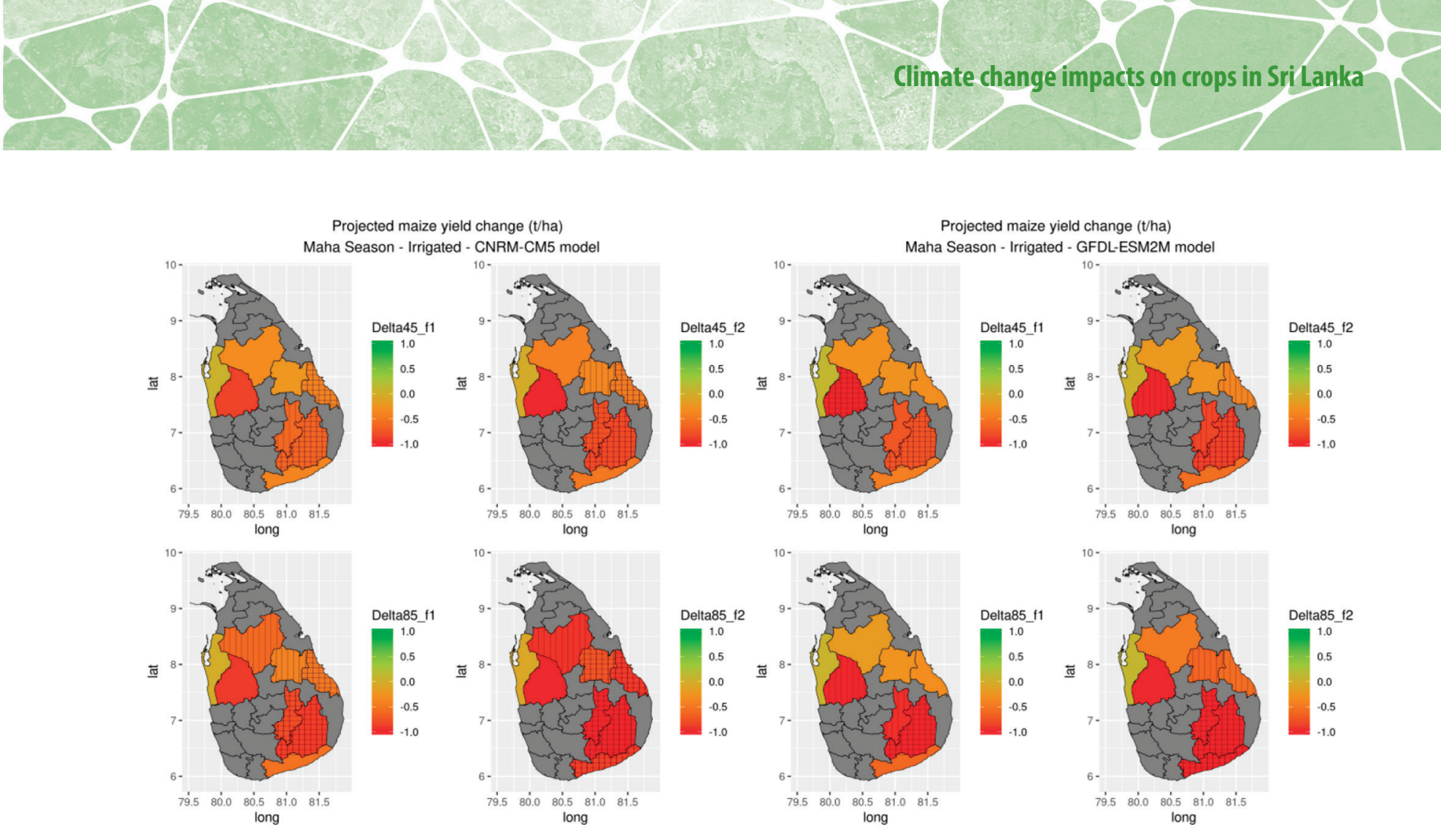

Source: UN. 2020. Map of the World [online]. [Cited 8 March 2021]. http://www.fao.org/geonetwork/srv/en/metadata.show?id=12691

Figure 20. Projected maize yield changes for the Maha season, irrigated regime,

according to CNRM-CM5 and GFDL-ESM2M models (tonnes/ha)
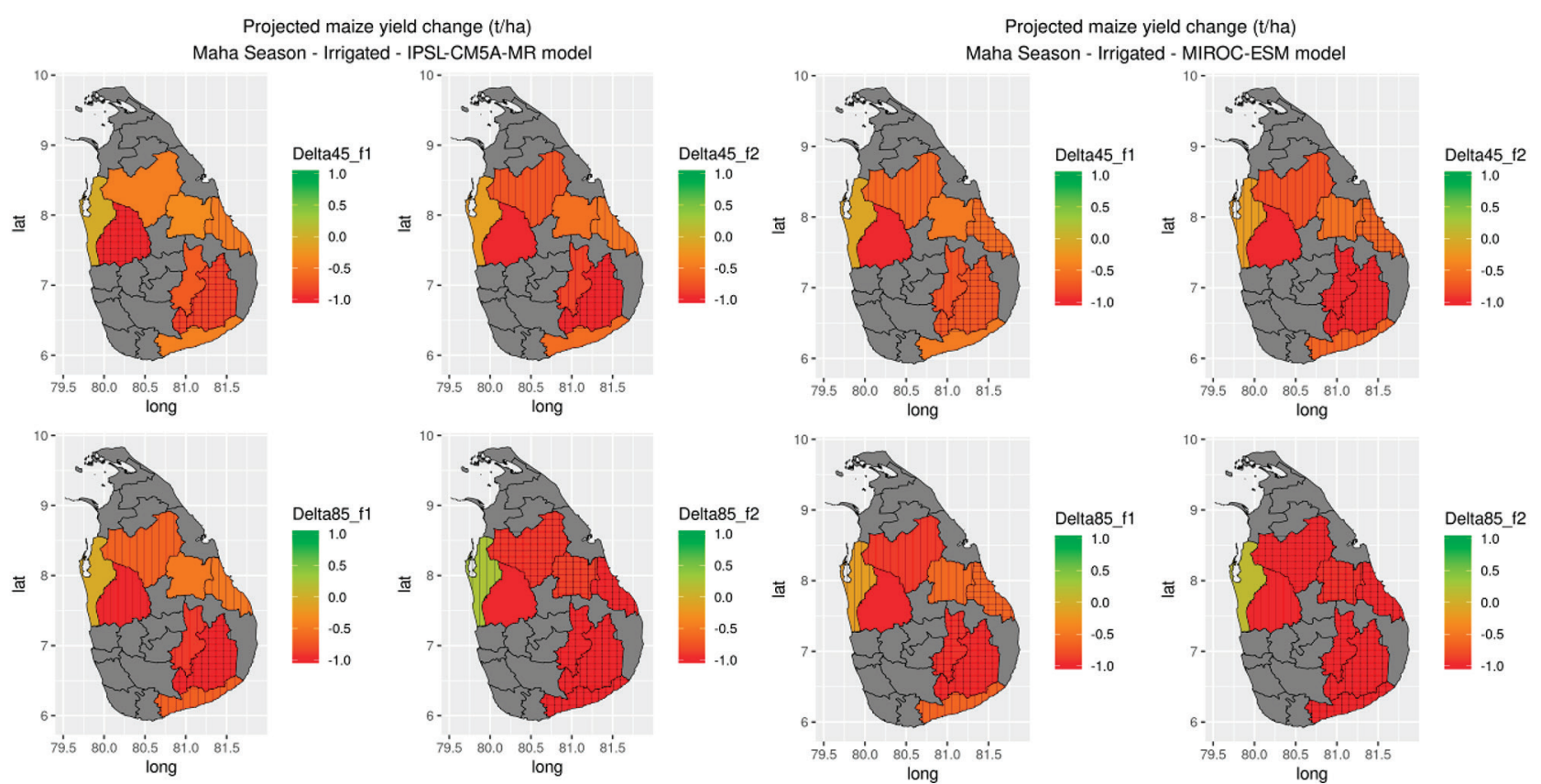

Source: UN. 2020. Map of the World [online]. [Cited 8 March 2021]. http://www.fao.org/geonetwork/srv/en/metadata.show?id=12691

Figure 21. Projected maize yield changes for the Maha season, irrigated regime, according to IPSL-CM5A-MR and MIROC-ESM models (tonnes/ha)

Notes: For each model in Figures 19-21, four maps are reported with projected changes for two RCPs (45 is RCP4.5; 85 is RCP8.5) and two future periods (f1 is middle future [2040-2069]; $\mathrm{f} 2$ is far future [2070-2100]]. Vertical lines denote projected changes larger than the historical standard deviation of yield anomaly and cross-hatch those more than twice as large. 


\section{Projected yield changes for maize, Yala season}

For the Yala season, impacts are positive in the districts of Polonnaruwa and Kurunegala for all models, while in Badulla and Moneragala they are negative (Figures 22-24). The yield functions of these two groups of districts showed, respectively, a positive and negative relationship with temperatures in the yield functions (Table 8).
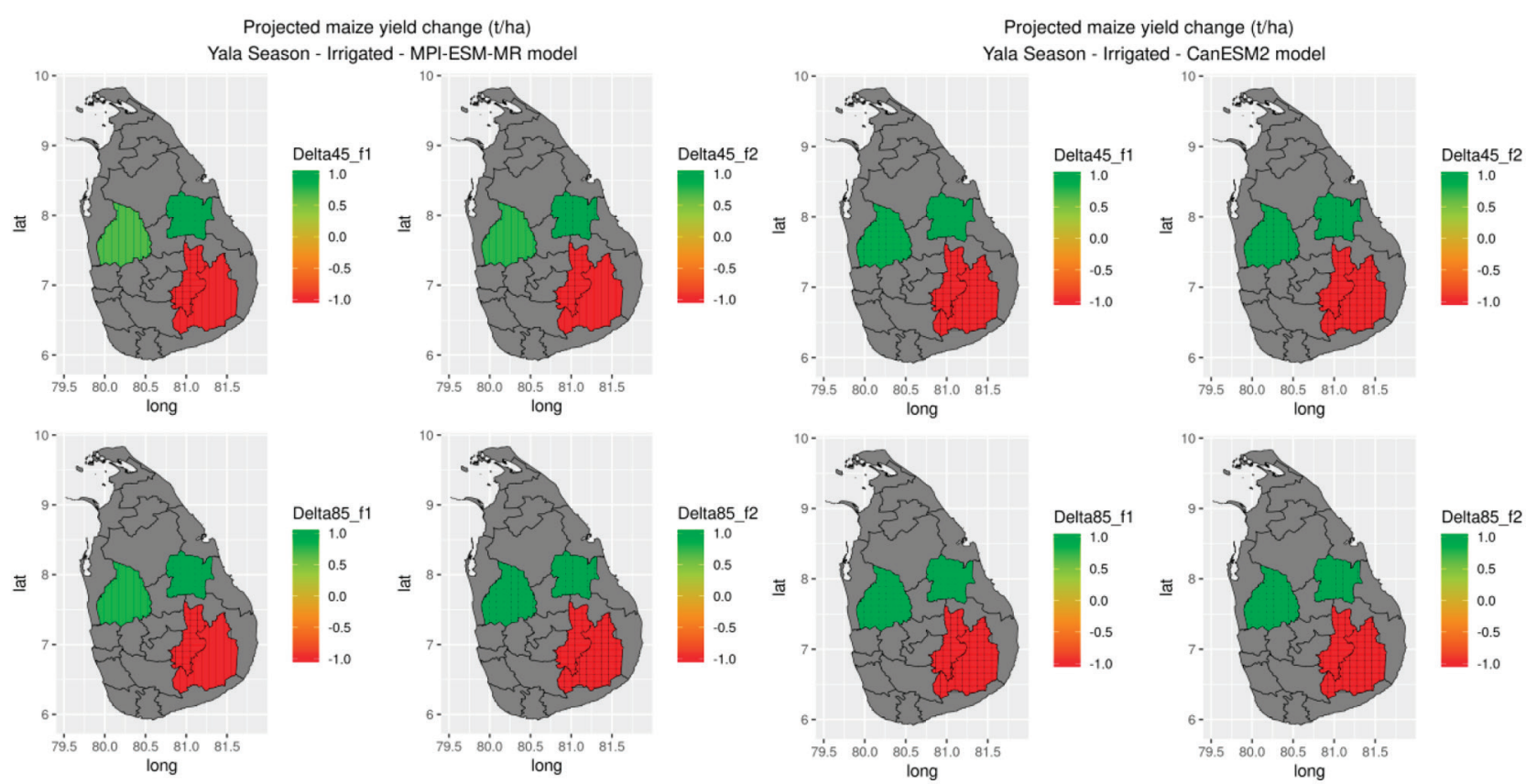

Source: UN. 2020. Map of the World [online]. [Cited 8 March 2021]. http://www.fao.org/geonetwork/srv/en/metadata.show?id=12691

Figure 22. Projected maize yield changes for the Yala season, irrigated regime, according to MPI-ESM-MR and CanESM2 climate models (tonnes/ha) 


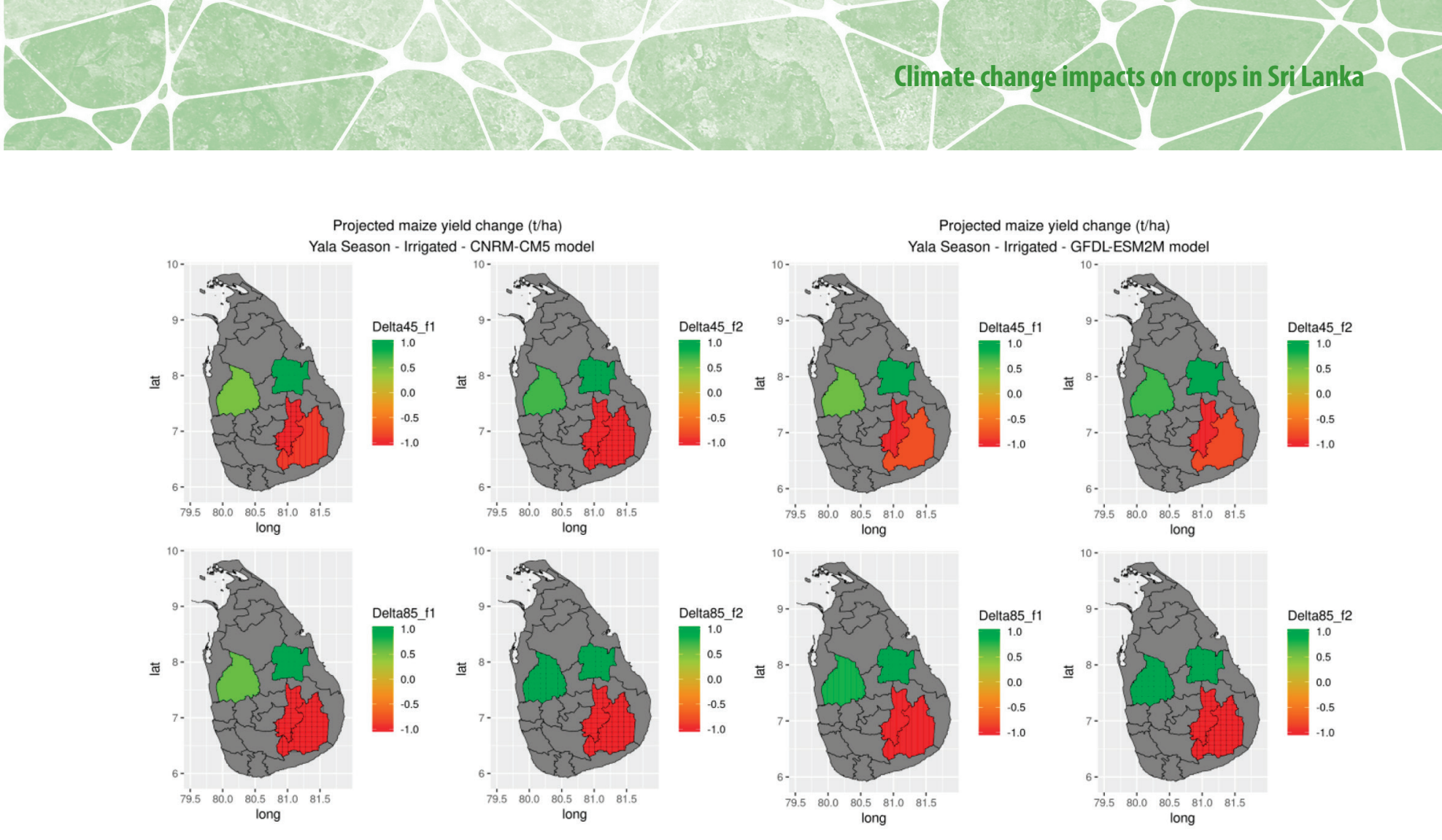

Source: UN. 2020. Map of the World [online]. [Cited 8 March 2021]. http://www.fao.org/geonetwork/srv/en/metadata.show?id=12691

Figure 23. Projected maize yield changes for the Yala season, irrigated regime, according to CNRM-CM5 and GFDL-ESM2M models (tonnes/ha)
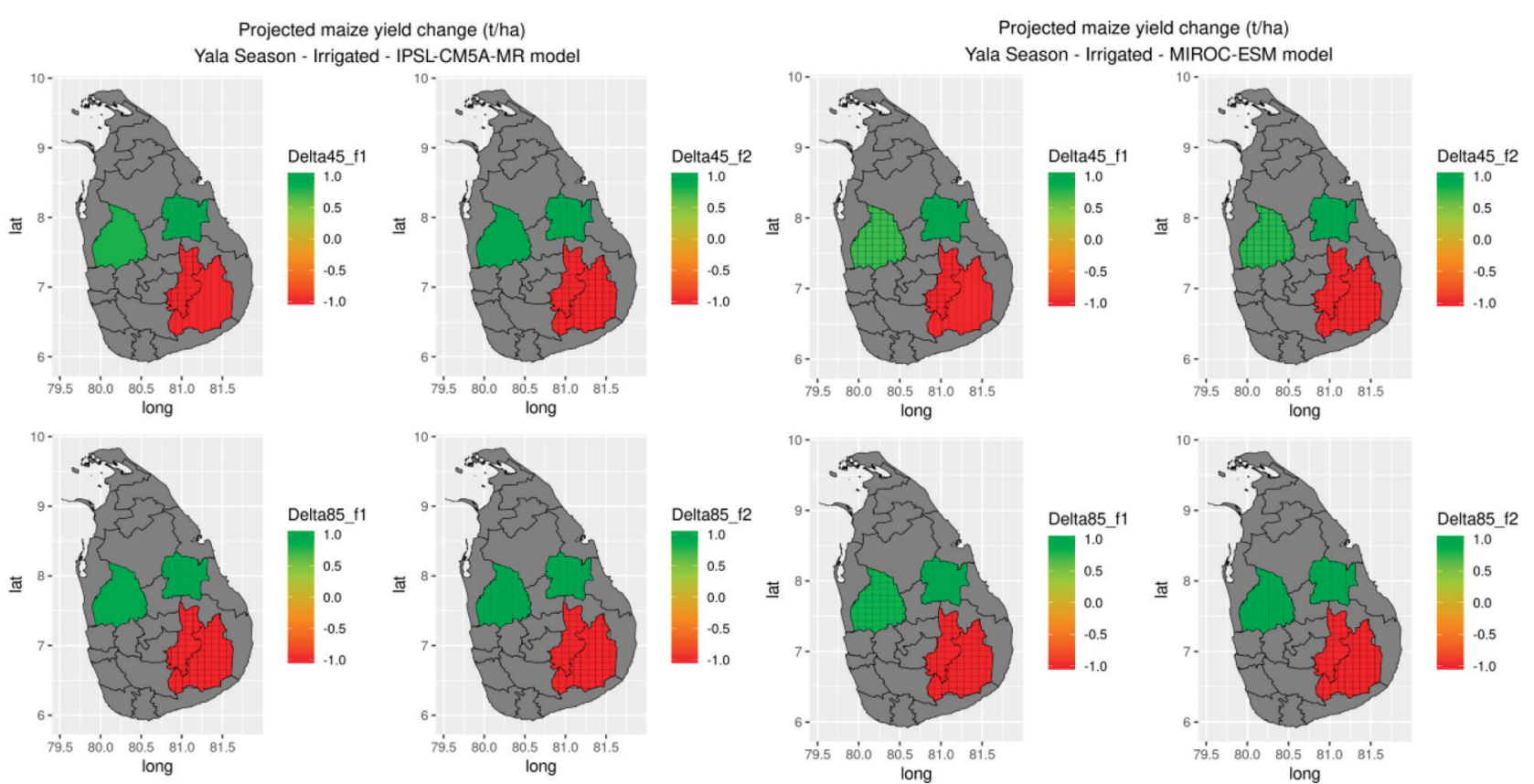

Source: UN. 2020. Map of the World [online]. [Cited 8 March 2021]. http://www.fao.org/geonetwork/srv/en/metadata.show?id=12691

Figure 24. Projected maize yield changes for the Yala season, irrigated regime, according to IPSL-CM5A-MR and MIROC-ESM models (tonnes/ha)

Notes: For each model in Figures 22-24, four maps are reported with projected changes for two RCPs (45 is RCP4.5; 85 is RCP8.5) and two future periods (f1 is middle future [2040-2069]; $\mathrm{f} 2$ is far future [2070-2100]. Vertical lines denote projected changes larger than the historical standard deviation of yield anomaly and cross-hatch those more than twice as large. 


\section{Big onion}

\section{Projected yield changes for big onion, Yala season}

All the models, for both scenarios and future horizons, project a positive change in big onion yields in the districts of Matale, Anuradhapura and Polonnaruwa situated in the dry and intermediate zones (Figures 25-27). Indeed, the yield functions of these districts are dominated by a positive and relatively strong relationship with both maximum and minimum temperatures (Table 9). Big onion is a crop that benefits from heat and high insolation, associated with high temperatures.
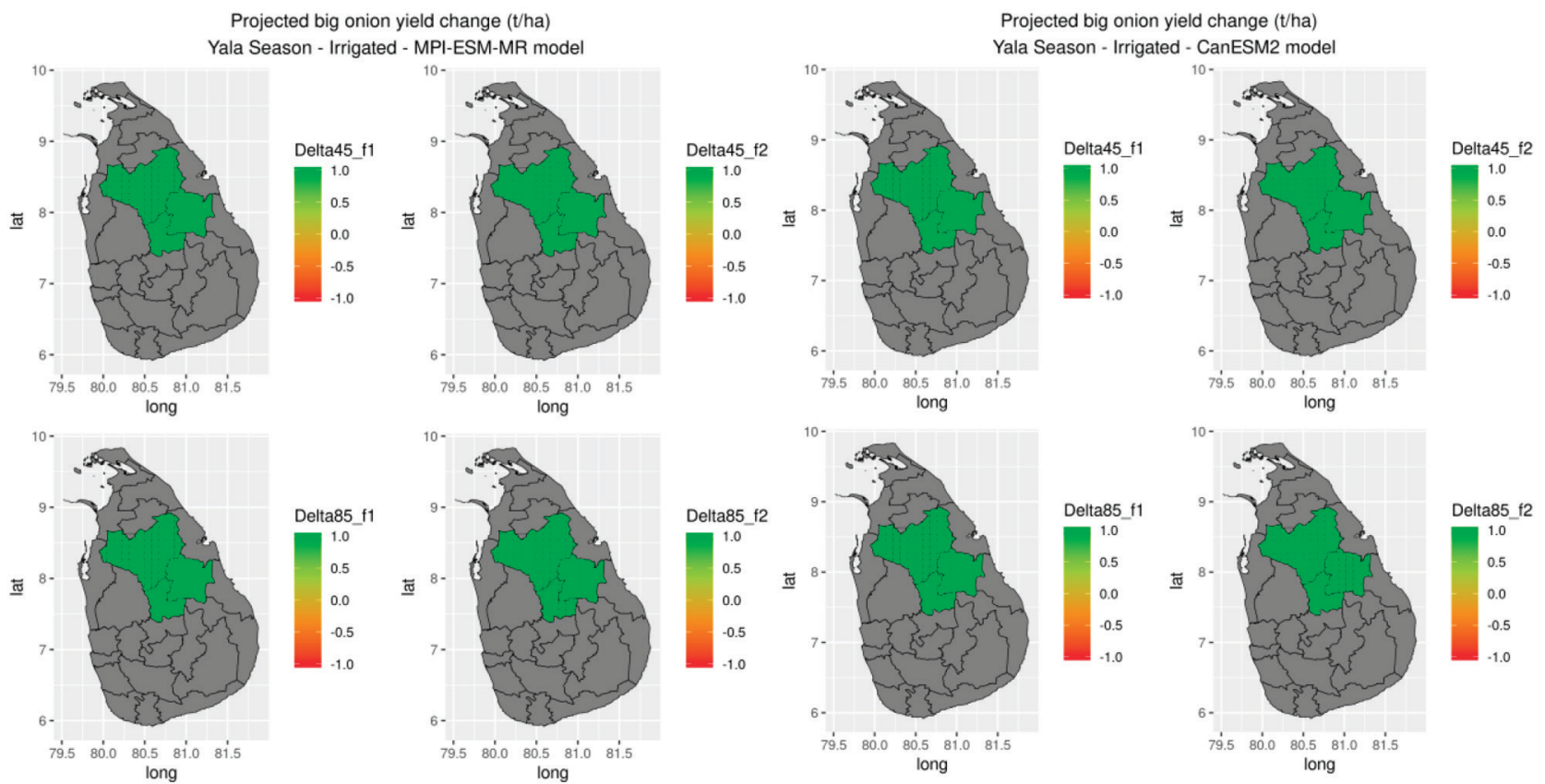

Source: UN. 2020. Map of the World [online]. [Cited 8 March 2021]. http://www.fao.org/geonetwork/srv/en/metadata.show?id=12691

Figure 25. Projected big onion yield changes for the Yala season, irrigated regime, according to MPI-ESM-MR and CanESM2 climate models (tonnes/ha) 


\section{Green gram}

\section{Projected yield changes for green gram, Maha season}

For both scenarios and future horizons, the six models project a slightly negative change in green gram yields in the districts of Moneragala, Hambantota, Puttalam and Anuradhapura situated between the intermediate zone and the dry zone (Figures 28-30). This can be attributed to the negative impacts of increasing temperatures (the yield function contains a negative relationship with $\operatorname{Tmin}_{2}, \operatorname{Tmin}_{1}$ and $\operatorname{Tmax}_{4}$ - see Table 10).

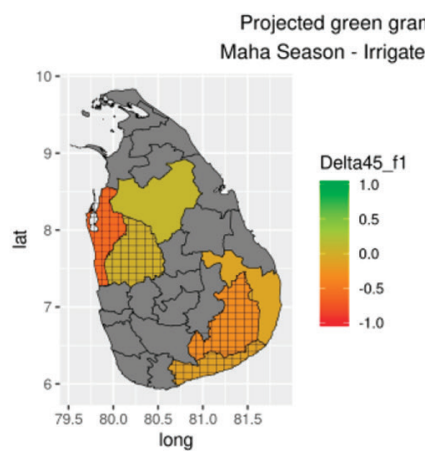

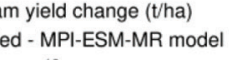
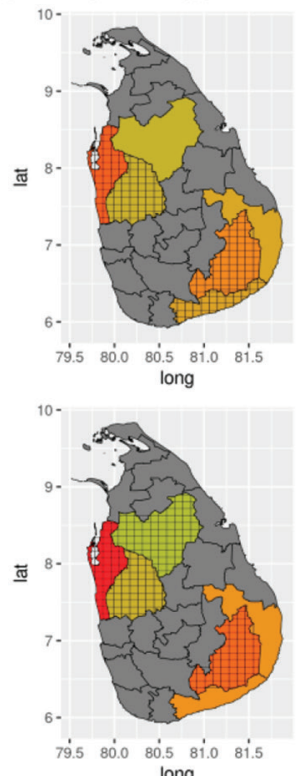
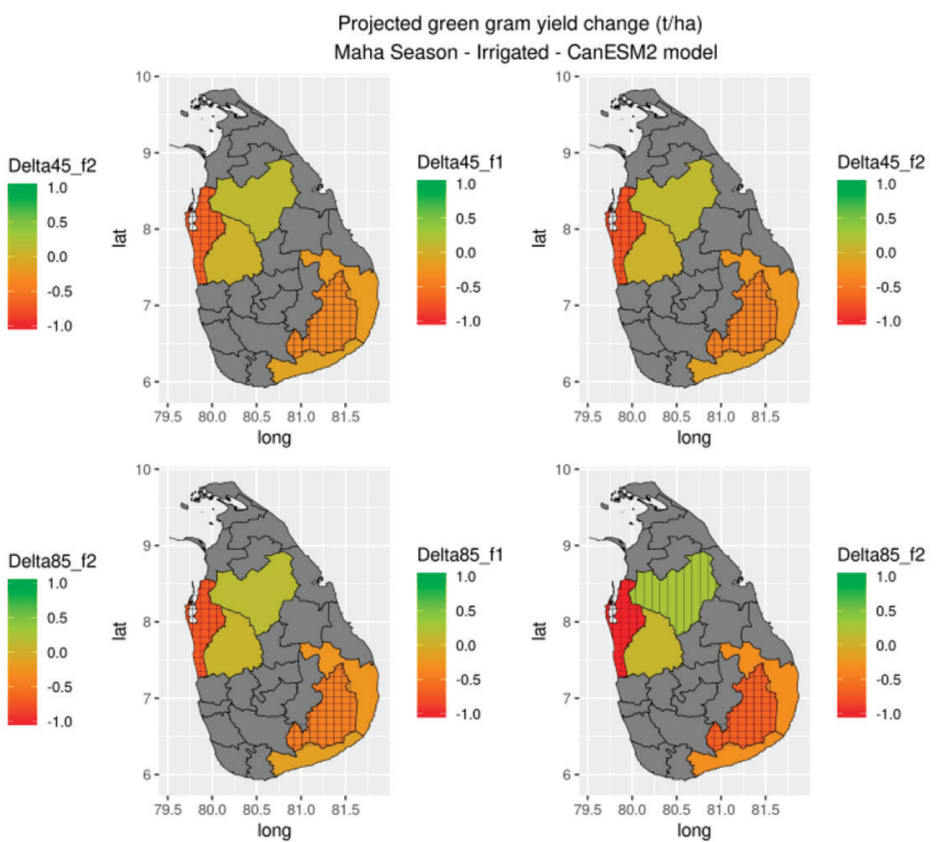

Source: UN. 2020. Map of the World [online]. [Cited 8 March 2021]. http://www.fao.org/geonetwork/srv/en/metadata.show?id=12691

Figure 28. Projected green gram yield changes for the Maha season, irrigated regime, according to MPI-ESM-MR and CanESM2 climate models (tonnes/ha) 


\section{Projected yield changes for green gram, Yala season}

In the Yala season, all the models for both future horizons and scenarios project a negative change of green gram yields in Moneragala District, while positive changes appear in Kurunegala District (Figures 31-33). This can be attributed to the negative and positive impacts of increasing temperatures in the Yala season (with yield functions containing negative coefficients of Tmin in Moneragala and positive Prec and Tmin coefficients in Kurunegala - see Table 10).
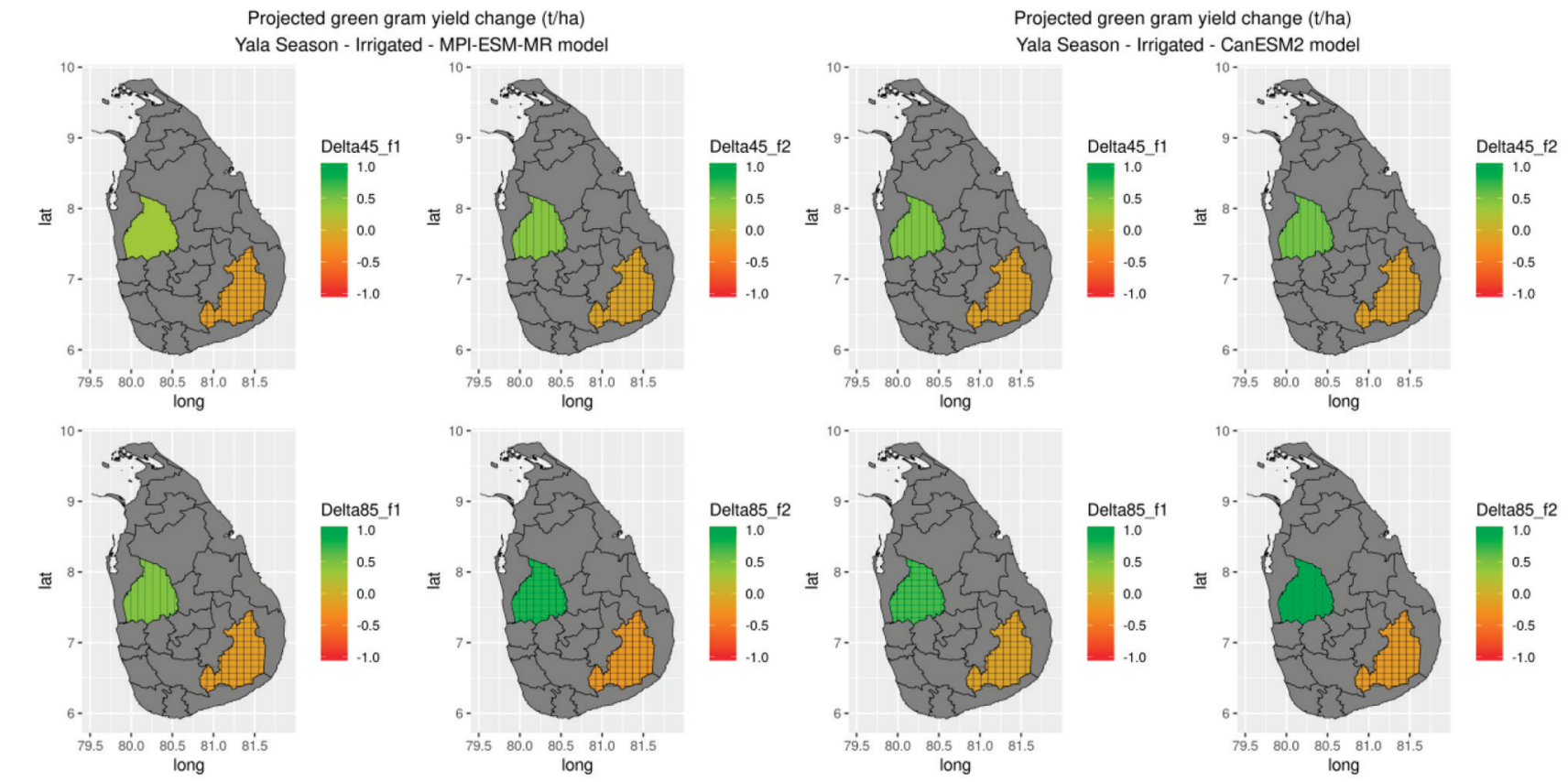

Source: UN. 2020. Map of the World [online]. [Cited 8 March 2021]. http://www.fao.org/geonetwork/srv/en/metadata.show?id=12691

Figure 31. Projected green gram yield changes for the Yala season, irrigated regime, according to MPI-ESM-MR and CanESM2 climate models (tonnes/ha) 


\section{Potato}

\section{Projected yield changes for potato, Maha season}

In the Maha season, all the models for both future horizons and scenarios project a negative change in potato yields in the district of Nuwara Eliya and a positive change in Jaffna (Figures 34-36). This can be attributed to the negative and positive impacts of increasing temperatures in the Maha season, with yield functions containing, respectively, a negative and positive coefficient of Tmin in Nuwara Eliya and Jaffna (Table 11).
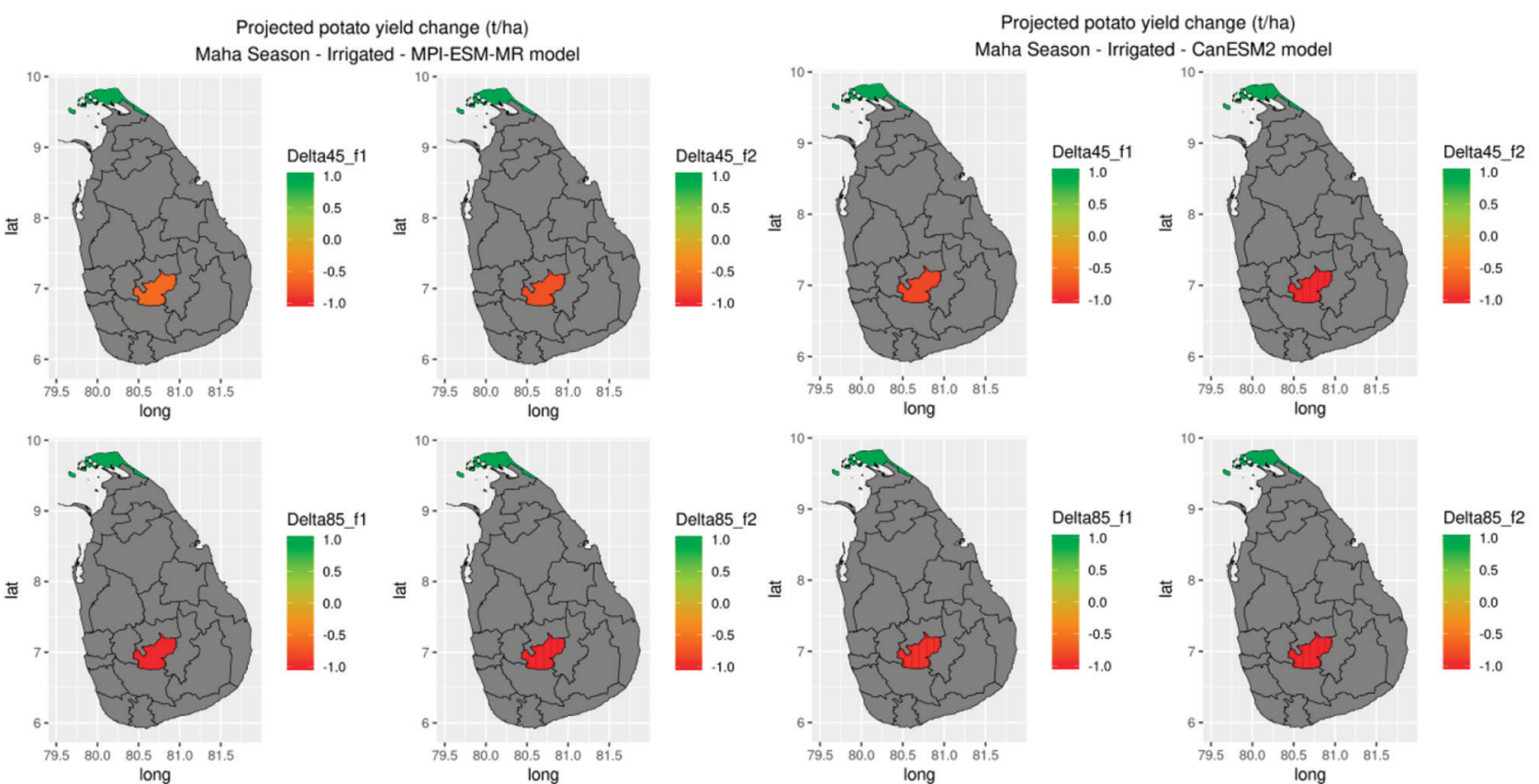

Source: UN. 2020. Map of the World [online]. [Cited 8 March 2021]. http://www.fao.org/geonetwork/srv/en/metadata.show?id=12691

Figure 34. Projected potato yield changes for the Maha season, irrigated regime, according to MPI-ESM-MR and CanESM2 climate models (tonnes/ha) 


\section{Projected yield changes for potato, Yala season}

In the Yala season, for all models and both future horizons and scenarios, a negative change in potato yields is expected in the district of Badulla, while positive changes are projected in Nuwara Eliya (Figures 37-39). The precipitation is positively and negatively correlated with the potato yield in the yield function (Table 11) in Nuwara Eliya and Badulla, respectively.
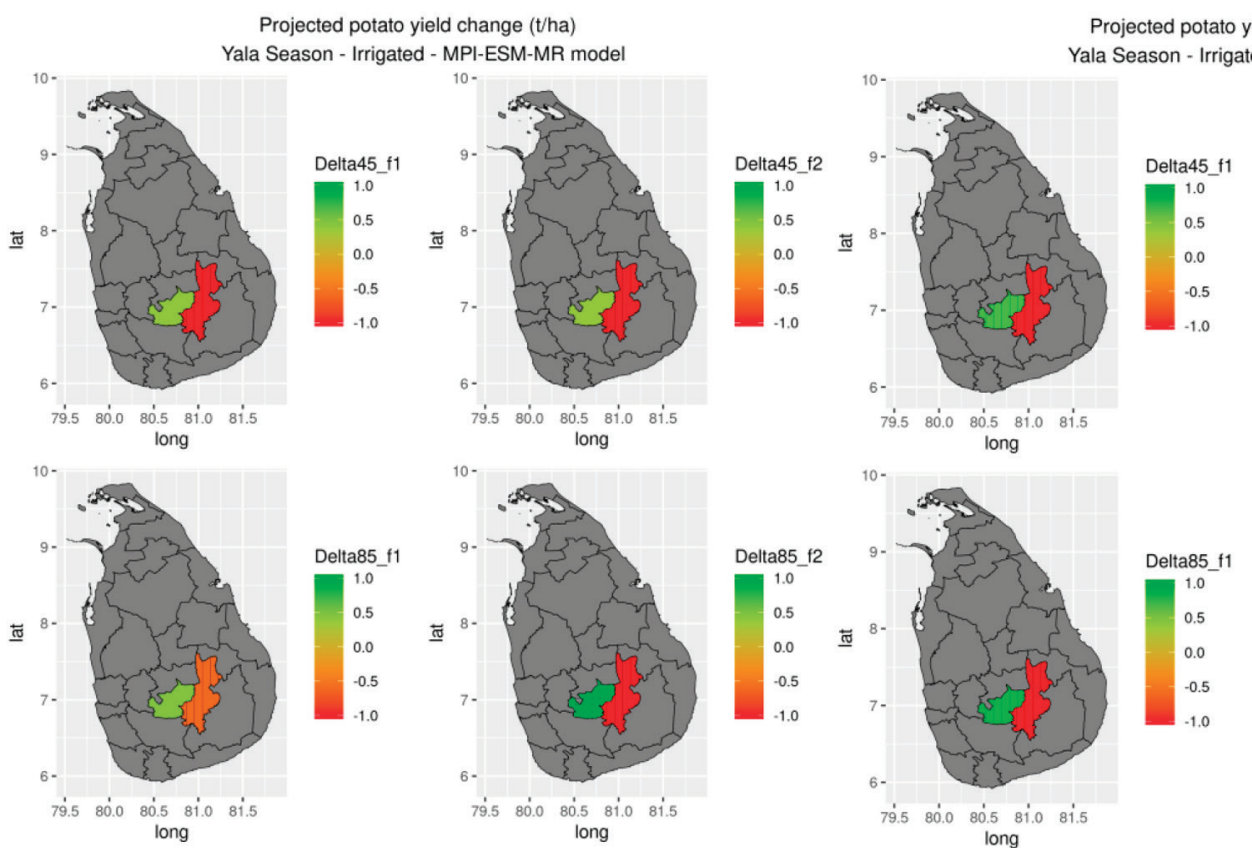

yield change (t/ha)
- CanESM2 model
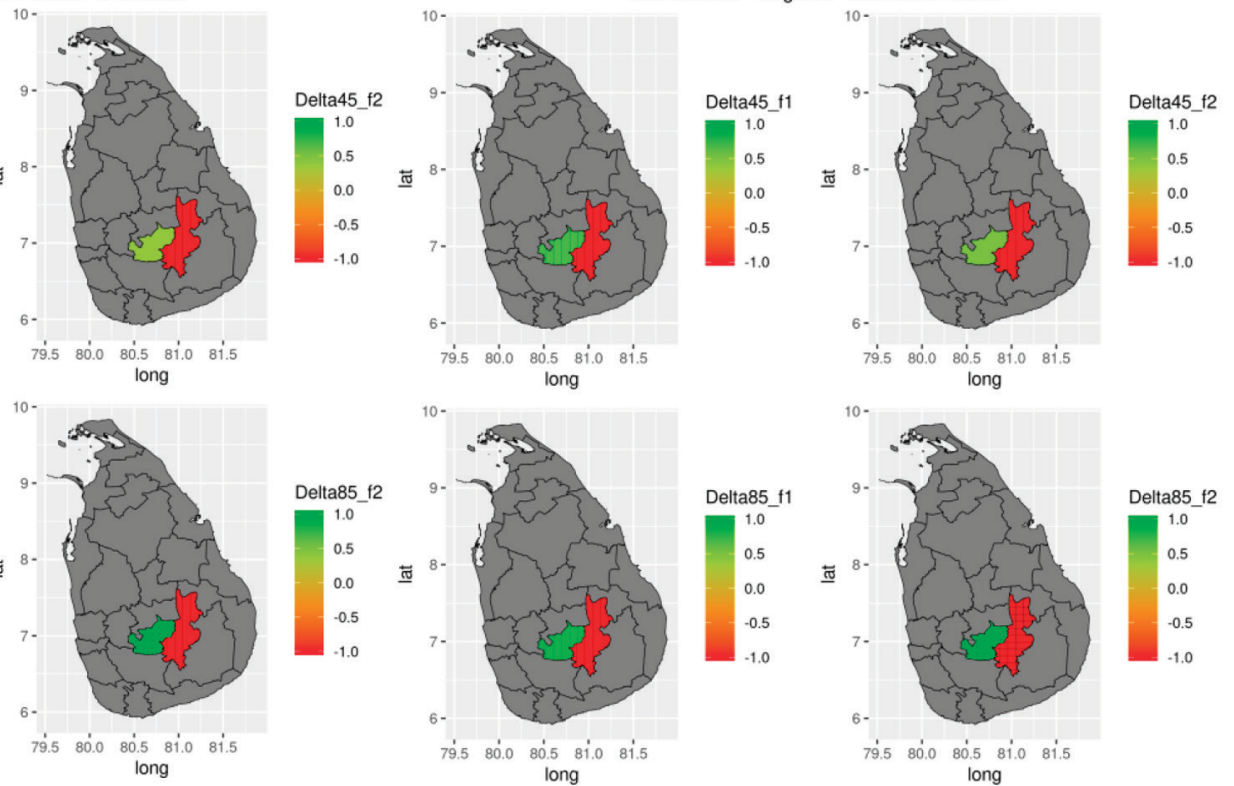

Source: UN. 2020. Map of the World [online]. [Cited 8 March 2021]. http://www.fao.org/geonetwork/srv/en/metadata.show?id=12691

Figure 37. Projected potato yield changes for the Yala season, irrigated regime, according to MPI-ESM-MR and CanESM2 climate models (tonnes/ha) 


\section{Chilli}

\section{Projected yield changes for chilli, Maha season}

For the Maha season, the situation is quite heterogeneous with both positive and negative projected impacts (Figures 40-42). Jaffna appears with positive impact and this can be explained by the positive relationship with temperature in the yield functions of the districts in the Maha season (Table 12).

Ampara and Anuradhapura, on the other hand, according to all the GCMs, present the greatest negative impacts. The yield function in those two districts is indeed dominated by negative dependency on maximum temperature and minimum temperature (Table 12).
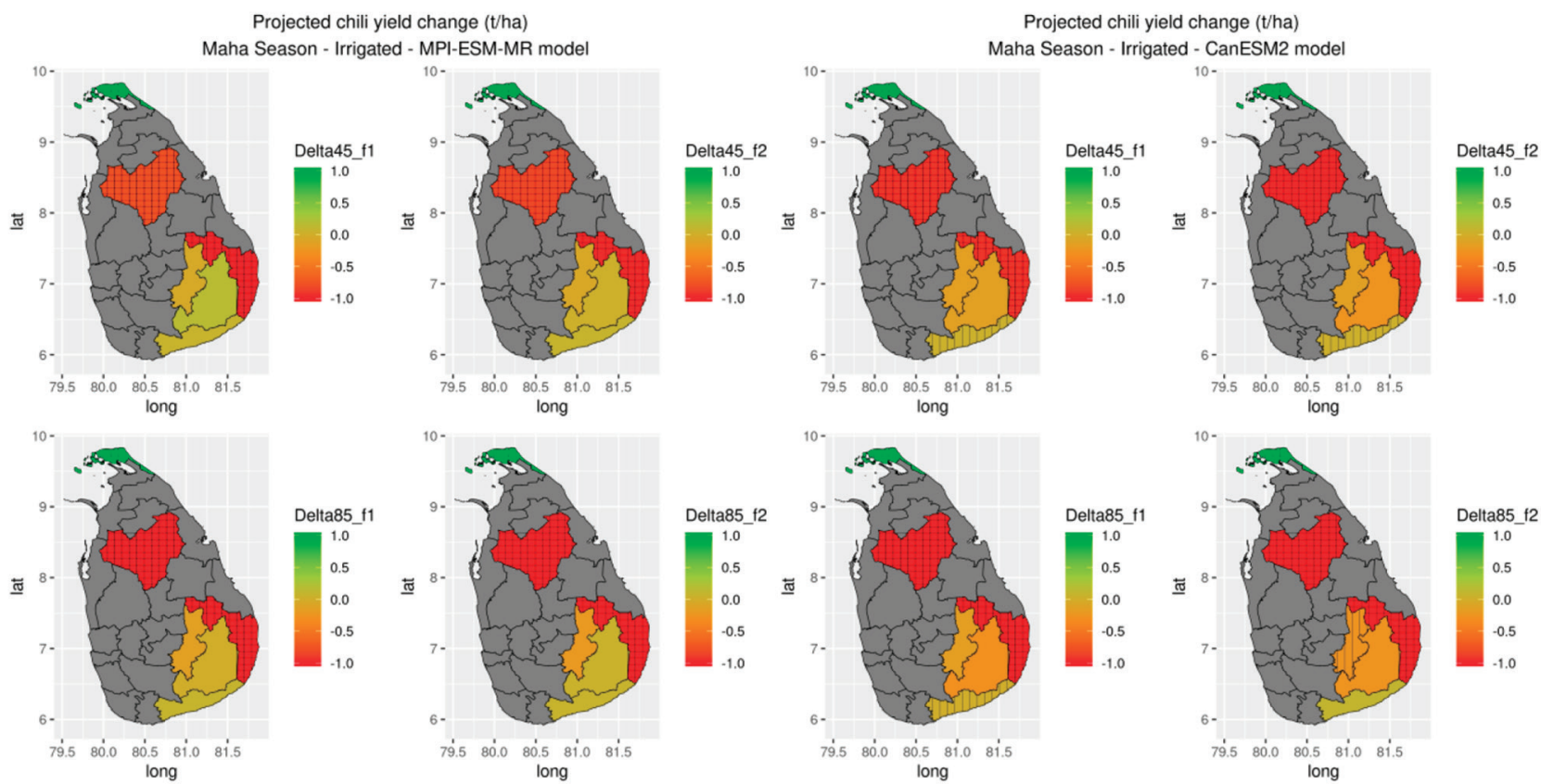

Source: UN. 2020. Map of the World [online]. [Cited 8 March 2021]. http://www.fao.org/geonetwork/srv/en/metadata.show?id=12691

Figure 40. Projected chilli yield changes for the Maha season, irrigated regime, according to MPI-ESM-MR and CanESM2 climate models (tonnes/ha) 


\section{Projected yield changes for chilli, Yala season}

In the Yala season, for all models, the future horizons for both scenarios project a positive change in chilli yields in Puttalam but negative changes in the districts of Hambantota, Badulla and Kurunegala (Figures 43-45). Temperature is positively correlated with the chilli yield in the yield function (Table 12), resulting in Puttalam having a positive future projection of yield change.
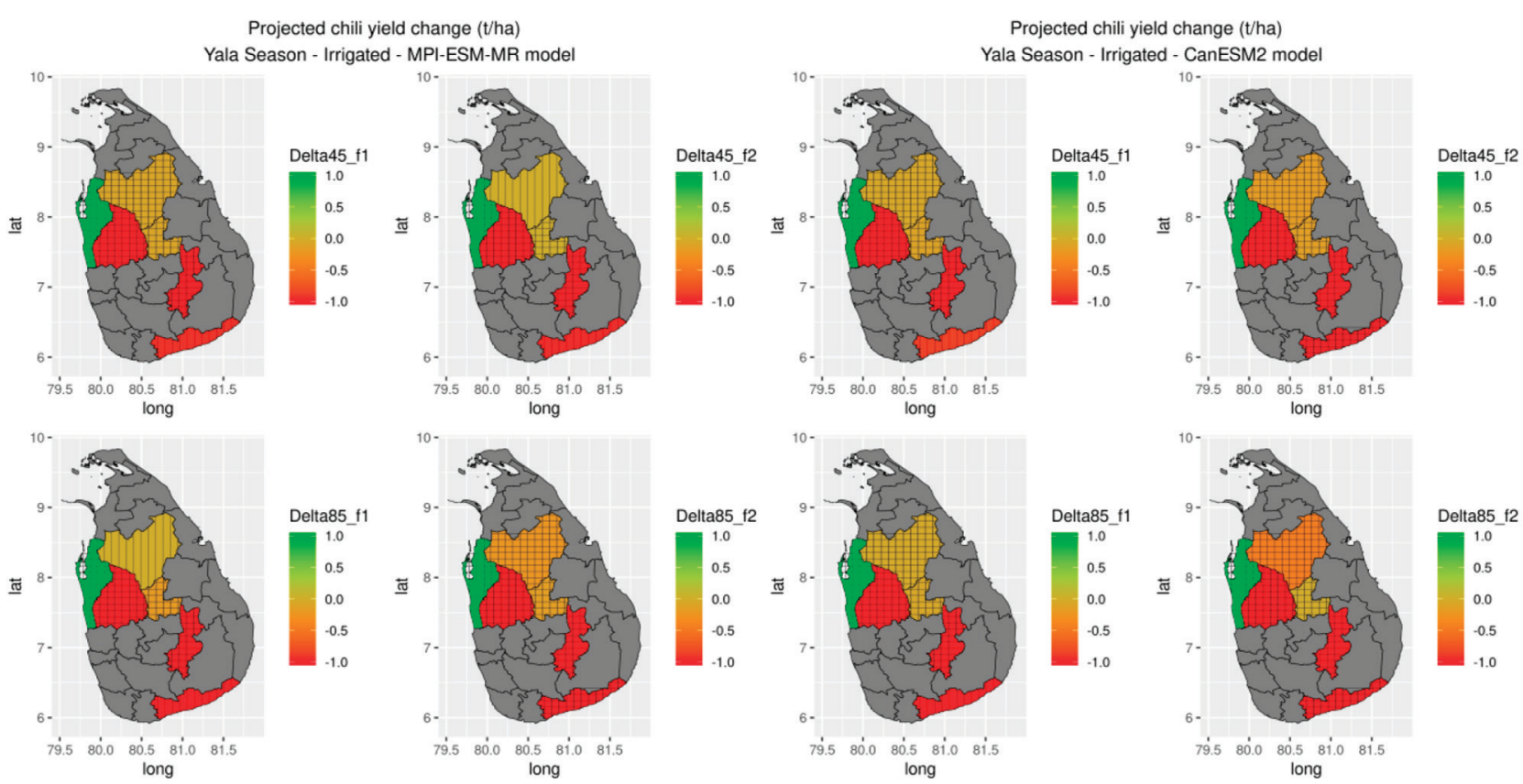

Source: UN. 2020. Map of the World [online]. [cited 8 March 2021]. http://www.fao.org/geonetwork/srv/en/metadata.show?id=12691

Figure 43. Projected chilli yield changes for the Yala season, irrigated regime, according to MPI-ESM-MR and CanESM2 climate models (tonnes/ha) 


\section{Conclusion and key takeaways}

The application of the MOSAICC methodology in Sri Lanka provides an interdisciplinary analysis of climate-driven changes in future crop yields for the selected crops relevant in the country. The combination of a simple but robust water balance model with a statistical approach to crop modelling supports the identification of the main climatic/water balance drivers of crop yields. The use of historical climate data from the country's meteorological network and the results of climate models derived from general circulation models, together with historical data of cultivated extent and yields, allows to benefit from high-quality observations of climate and crop data, state-of-the art projected climate, and well-established crop modelling methods. The statistical relationships identified for the historical period are applied to produce projections of future yield changes, as an indicator of the climate change impact on the crop according to specific locations, seasons and irrigation regimes.

\subsection{Climate change impacts on selected crops}

The main findings of the impact assessment carried out with MOSAICC are outlined below for each crop.

\section{Rice}

In the Yala season under the irrigated regime, future projected yield changes are generally positive in the wet, intermediate and dry zones. In the Maha season, rainfed and irrigated regimes both show generally negative impacts, especially in the lowlands (Anuradhapura district). For seven locations, the findings are consistent with a climate change impact study conducted with a process-based model (APSIM) for the dry, intermediate and wet zones (Amarasingha et al., 2018). In selected DZ locations, positive impacts of climate change are projected during the Maha season, while opposite behaviour is estimated for the Yala season in the same areas.

A climate change impact study was conducted with APSIM and DSSAT for the districts of Anuradhapura and Kurunegala, with climate data from five GCMs (Devkota et al., 2013). This study quantified the effects of projected increases in temperature and atmospheric $\mathrm{CO}_{2}$ concentration on the phenological development and grain yield of rice using the ORYZA2000 simulation model. The model was parameterized and validated on the basis of data sets from three field experiments with three widely cultivated rice varieties under various seeding dates in the 2008-09 growing seasons in the Khorezm region of Uzbekistan. The selected rice varieties represent short-duration, mediumduration and long-duration maturity types, showing potential negative impacts of climate change, consistently with the results of the MOSAICC analysis.

The base, optimum and maximum temperatures for rice are $8^{\circ} \mathrm{C}, 30^{\circ} \mathrm{C}$ and $42^{\circ} \mathrm{C}$, respectively (Gao et al., 1992). The development rate of rice increases linearly above the base temperature to 
the optimum temperature. Beyond the optimum temperature, the development rate decreases linearly until a maximum temperature is reached (Kiniry et al., 1991). Below the base temperature or above the maximum temperature, the development rate is zero. Furthermore, flowering is longer at a mean temperature of $33^{\circ} \mathrm{C}$ in comparison to $29^{\circ} \mathrm{C}$ (Matthews et al., 1995). The historical data show that the average maximum temperature of the dry zone in the Maha season is around $30^{\circ} \mathrm{C}$. The average maximum and minimum temperatures in the Yala season in the wet zone are $29^{\circ} \mathrm{C}$ and $24^{\circ} \mathrm{C}$, respectively. In the DZ Maha season and the WZ Yala season, minimum and night temperatures, which generally cause spikelet sterility and yield reduction in rice (Peng et al., 2004), are generally low. Thus, the projected future climatic conditions (increased temperatures) could provide greater opportunities for rice cultivation and yield increases. Increasing $\mathrm{CO}_{2}$ may influence rice yield positively by increasing the amount of carbon available for photosynthesis, and negatively by increasing the air temperature due to the greenhouse effect (Krishnan et al., 2011). However, in contrast to other earlier findings, higher simulated yields under climate change scenarios indicate that an increase in photosynthesis due to enhanced $\mathrm{CO}_{2}$ could surpass the negative effect of increased temperature on yield (De Costa, 2010; Delpitiya et al., 2014; Devkota et al., 2013). This is in agreement with observations in India (Devkota et al., 2013; Krishnan et al., 2007) and in the United States (Baker, 2004).

During the Maha season, in the wet zone, even with the optimum maximum and minimum temperature conditions, yield reduction could be possible due to high rainfall and flooding conditions. In the wet zone, soil has higher clay percentage and lower sand content. Therefore, the upper limit for drainage is low. With flooding conditions, the rice yield could be reduced. Many earlier findings (Baker, Allen and Boote, 1992; Matthews et al., 1995; van Oort and Zwart, 2018; Peng et al., 2004; Sheehy, Mitchell and Ferrer, 2006) show that yield reduction of rice under climate change scenarios in Asia can happen.

\section{Maize}

In general, negative yield changes are projected during the Maha season in dry and intermediate zones, while both negative and positive yield changes are projected in the Yala season. The results for maize are partially consistent with a climate change impact study recently conducted with a processbased model (APSIM) for 25 different locations, representing the dry, intermediate and wet zones (Amarasingha et al., 2019). The results of the APSIM study also project negative impacts of climate change during both Yala and Maha seasons. Furthermore, the study conducted by Malaviarachchi et al. (2015) also reveals a negative impact of increased temperature due to climate change on maize yield. These results are consistent with MOSAICC projections, with maize yields negatively affected throughout Sri Lanka irrespective of the cultivation season.

Previous studies (Guereña et al., 2001; Long, 1991; Tao and Zhang, 2011) suggested that increased temperature shortened the length of the growing cycle, by decreasing the opportunity to capture more radiation and reducing the total $\mathrm{CO}_{2}$ assimilation, and reducing the total biomass and grain yield. 


\section{Green gram}

Earlier results with the APSIM model (Amarasingha et al., 2019) show negative impacts of climate change on green gram yields for specific locations throughout the country. Similar results are predicted also by Malaviarachchi et al. (2015) with negative impacts of climate change on green gram throughout Sri Lanka, irrespective of the season, and significant reduction in yield when growing temperatures increase beyond $25-30^{\circ} \mathrm{C}$. Increased temperature shortens crop duration and reduces leaf area index and thus decreases biomass production (Chauhan and Williams, 2018). According to Malaviarachchi et al. (2015), it is highly likely that future increases in air temperature would have negative impacts on green gram yields in Sri Lanka and Southeast Asia. MOSAICC results are generally consistent with previous studies: overall, for both Maha and Yala seasons, impacts are projected to be slightly negative, and relevant predictors in the yield functions are temperatures with mostly negative coefficients. This is in line with the analysis from Karande et al. (2018).

\section{Big onion}

Climate change impact on big onion is projected to be positive in the Yala season; however, national references for the crop are not available for a comparison of crop yield projections with climate change. Big onion is a long-day crop; in order to reach maximum yield, it requires a day length of more than 12 hours and cumulative rainfall not exceeding $750 \mathrm{~mm}$ throughout the cropping season. Although insolation and day length are not predictors in the models, they are directly related to temperature and the difference between maximum and minimum temperature. The modelled increase in yields in the Yala season is most likely the result of the relationship between insolation and temperature.

\section{Potato}

Potato is extensively cultivated in the highlands, in the districts of Nuwara Eliya (upcountry WZ), and Badulla (upcountry IZ) in both Yala and Maha seasons. It is also cultivated in Jaffna during the Maha season. The climate change impact on potato according to MOSAICC is negative in Nuwara Eliya, in both Yala and Maha seasons, while in Jaffna District during the Maha season when temperatures are cooler, the projected yield changes are positive. According to Abhayapala et al. (2014), potato yield in the upcountry wet zone (Seethaeliya, Rahangala) did not decrease significantly when the seasonal mean temperature increased from $15^{\circ} \mathrm{C}$ to $20^{\circ} \mathrm{C}$.

\section{Chilli}

In the Maha season, the projected impacts on chilli cultivation are somewhat heterogeneous with both positive and negative yield changes, mostly explained by both maximum and minimum temperature indices appearing in the yield functions. Also in the Yala season, the projections are heterogeneous, with positive changes in Puttalam District and negative changes in the districts of Hambantota, Badulla and Kurunegala. 
Temperature, rather than precipitation, is considered to be the main determinant of crop yield (Li et al., 2010; Lobell and Burke, 2010; Lobell and Field, 2007; Porter et al., 2014). There is a significant decrease in yield when growing temperatures increase (Abhayapala et al., 2018). National references are unavailable to compare the results obtained with MOSAICC for chilli, but the prevalence of temperatures as predictors in the yield functions is in line with previous studies on this crop. Drought conditions could also adversely affect the germination of seeds, with further negative effects on crop growth and development. It is estimated that due to limited availability of water for irrigation, the cultivation of chilli is possible in only 16 percent of the potential arable area.

In general, MOSAICC results are consistent with previous studies despite the different approaches applied, with most of the previous work on the selected crops using process-based models but not the daily outputs of GCMs. The present methodology is flexible and presents great potential for improvement and enrichment of results by refining the modelling/analysis choices and integrating new data sets and information into the MOSAICC database.

The promising results underline the need to push forward with the efforts to improve models, test and compare different methodologies, and continue to support the national institutions involved in climate change impact assessment exercises for the production, quality control and analysis of data and metadata.

\subsection{Extended benefits of the MOSAICC approach}

In addition to the scientific results presented above for six relevant crops, the implementation and use of MOSAICC was also an opportunity to gather national data from different sources and locations, at different spatial scales (station, district, province and country level), on both climate and crops. The wide, composite and quality-controlled collection of data and information assembled can be used for any future analysis and modelling exercises on the agricultural impacts of climate change.

The effort behind the collection, sharing and quality control of data created an opportunity for interinstitutional exchanges and joint work. The MOSAICC approach values the country's meteorological network, agricultural and statistics institutions for the collection of long-time series of high-quality data and metadata and of information from the country's scientific and technical literature, essential for this analysis.

Furthermore, the MOSAICC system, which relies on a multi-user, multi-model platform, remains installed in the country, available to re-run the impact assessment exercise at any time, should new data become available or the country's priorities change. Moreover, the country has the benefit of compiled and consolidated data sets, rigorously quality checked and aggregated by region for historical and future time periods with the potential to contribute to future projects and studies. 


\section{Bibliography}

Abeysiriwardena, D.S.D.Z., Ohba, K. \& Maruyama, A. 2002. Influence of temperature and relative humidity on grain sterility in rice. Journal of the National Science Foundation of Sri Lanka, 30: 33-41 [online]. [Cited 9 November 2020]. https://doi.org/10.4038/jnsfsr.v30i1-2.2559

Abhayapala, K.M.R.D., De Costa, W.A.J.M., Fonseka, R.M., Prasannath, K., De Costa, D.M., Suriyagoda, L.D.B., Abeythilakarathne, P.D. \& Nugaliyadde, M.M. 2014. Response of potato (Solanum tuberosum L.) to increasing growing season temperature under different soil management and crop protection regimes in the upcountry of Sri Lanka. Tropical Agricultural Research, 25: 555-569.

Abhayapala, R., De Costa, J., Malaviarachchi, W., Kumara, A., Suriyagoda, L. \& Fonseka, R. 2018. Exploitation of differential temperature-sensitivities of crops for improved resilience of tropical smallholder cropping systems to climate change: A case study with temperature responses of tomato and chilli. Agriculture Ecosystems \& Environment, 261: 103-114 [online]. [Cited 9 November 2020]. https://doi.org/10.1016/j.agee.2017.10.027

\section{Amarasingha, R.K., Suriyagoda, L.D.B., Marambe, B., Galagedara, L.W. \& Punyawardena, R.} 2018. Impact of climate change on rice yield in Sri Lanka: crop modelling approach using Agriculture Production System Simulator (APSIM). Sri Lanka Journal of Food and Agriculture, 4(1): 21-26 [online]. [Cited 9 November 2020]. https://doi.org/10.4038/sljfa.v4i1.54

Amarasingha, R.P.R.K., Suriyagoda, L.D.B., Marambe, B. \& Galagedara, L.W. 2019. Evaluating the crop productivity and stability of major rice based annual cropping systems of Sri Lanka using crop model - APSIM. Faculty of Agriculture. University of Peradeniya. Sri Lanka. (Thesis)

Baker, J.T. 2004. Yield responses of southern US rice cultivars to $\mathrm{CO}_{2}$ and temperature. Agricultural and Forest Meteorology, 122(3-4): 129-137 [online]. [Cited 9 November 2020]. https://doi. org/10.1016/j.agrformet.2003.09.012

Baker, J.T., Allen, L.H. \& Boote, K.J. 1992. Temperature effects on rice at elevated $\mathrm{CO}_{2}$ concentration. Journal of Experimental Botany, 43(7): 959-964 [online]. [Cited 9 November 2020]. https://doi. org/10.1093/jxb/43.7.959

Balaghi, R., El Hairech, T., Alaouri, M., Motaouakil, S., Benabdelouahab, T., Mounir, F., Lahlou, M. et al. 2016. Climate change impact assessment using MOSAICC in Morocco. Morocco, INRA.

Bénichou, P. \& Le Breton, O. 1987. AURELHY: une méthode d'analyse utilisant le relief pour les besoins de l'hydrométéorologie. In Deuxièmes journées hydrologiques de l'ORSTOM à Montpellier, pp. 299-304. Colloques et Séminaires. Paris, ORSTOM. 
Bouman, B.A.M. 2001. Water-efficient management strategies in rice production. International Rice Research Notes, 26(2): 17-22.

Central Bank of Sri Lanka (CBSL). 2018. Annual Report 2018 [online]. Colombo. [Cited 9 November 2020]. https://www.cbsl.gov.lk/en/publications/economic-and-financial-reports/annualreports/annual-report-2018

Chandrajith, R. 2020. Geology and geomorphology. In R.B. Mapa, ed. The soils of Sri Lanka, pp. 2334. World Soils Book Series. Switzerland, Springer.

Chauhan, Y.S. \& Williams, R. 2018. Physiological and agronomic strategies to increase mungbean yield in climatically variable environments of northern Australia. Agronomy, 8(6): 83 [online]. [Cited 9 November 2020]. https://doi.org/10.3390/agronomy8060083

Chen, H., Xu, C.-Y. \& Guo, S. 2012. Comparison and evaluation of multiple GCMs, statistical downscaling and hydrological models in the study of climate change impacts on runoff. Journal of Hydrology, 434-435: 36-45 [online]. [Cited 9 November 2020]. https://doi.org/10.1016/j.jhydrol.2012.02.040

Chylek, P., Li, J., Dubey, M.K., Wang, M. \& Lesins, G. 2011. Observed and model simulated 20th century Arctic temperature variability: Canadian Earth System Model CanESM2. Atmospheric Chemistry and Physics Discussion, 11: 22893-22907 [online]. [Cited 9 November 2020]. https://doi. org/10.5194/acpd-11-22893-2011

De Costa, W.A.J.M. 2000. Prediction of the effects of elevated $\mathrm{CO}_{2}$ and temperature on irrigated rice varieties in the low-country dry zone of Sri Lanka using a process-based simulation model. Journal of the National Science Foundation of Sri Lanka, 28(3): 165-184 [online]. [Cited 9 November 2020]. https://doi.org/10.4038/jnsfsr.v28i3.2659

De Costa, W.A.J.M. 2010. Adaptation of agricultural crop production to climate change: a policy framework for Sri Lanka. Journal of the National Science Foundation of Sri Lanka, 38(2): 79-89 [online]. [Cited 9 November 2020]. https://doi.org/10.4038/jnsfsr.v38i2.2032

\section{De Costa, W.A.J.M., Weerakoon, W.M.W., Herath, H.M.L.K. \& Abeywardena, R.M.I. 2003.} Response of growth and yield of rice (Oryza sativa) to elevated atmospheric carbon dioxide in the subhumid Zone of Sri Lanka. Journal of Agronomy and Crop Science, 189: 83-95 [online]. [Cited 9 November 2020]. https://doi.org/10.1046/j.1439-037X.2003.00013.x

Delpitiya, D.G.P.S., Weerakoon, W.M.W., Nissanka, S.P., Punyawardena, B.V.R., Karunarathne, M.A. \& Herath, R.M. 2014. Impacts of climate change on rice yields in Sri Lanka: a crop modelling approach using decision support system for agro technology transfer (DSSAT4.5). Annals of the Sri Lanka Department of Agriculture, 16: 71-81. 
Department of Census and Statistics. 2019. Food balance sheet, 2013-2017 [online]. Ministry of Economic Reform and Public Distribution, Sri Lanka. [Cited 9 November 2020]. http://www. statistics.gov.lk/Resource/en/Agriculture/FoodBalanceSheet/FBS_Report2013-2017.pdf

\section{Devkota, K.P., Manschadi, A.M., Devkota, M., Lamers, J.P.A., Ruzibaev, E., Egamberdiev, O.,} Amiri, E. \& Vlek, P.L.G. 2013. Simulating the impact of climate change on rice phenology and grain yield in irrigated drylands of central Asia. Journal of Applied Meteorology and Climatology, 52(9): 2033-2050 [online]. [Cited 9 November 2020]. https://doi.org/10.1175/JAMC-D-12-0182.1

Dharmarathna, W.R.S.S., Weerakoon, S.B., Rathnayake, U.R. \& Hearth, S. 2012. Variation of irrigated rice yield under the climate change scenarios. In Proceedings of the SAITM Research Symposium on Engineering Advancements, Malabe, Sri Lanka, pp. 31-34.

Dibike, Y.B. \& Coulibaly, P. 2005. Hydrologic impact of climate change in the Saguenay watershed: comparison of downscaling methods and hydrologic models. Journal of Hydrology, 307(1-4): 145163 [online]. [Cited 9 November 2020]. https://doi.org/10.1016/j.jhydrol.2004.10.012

DoA. 2018. AgStat. Vol. XV. Peradeniya, Socio Economics and Planning Centre, Department of Agriculture.

Dufresne, J.-L., Foujols, M.-A., Denvil, S., Caubel, A., Marti, O., Aumont, O., Balkanski, Y. et al. 2013. Climate change projections using the IPSL-CM5 Earth system model: from CMIP3 to CMIP5. Climate Dynamics, 40: 2123-2165 [online]. [Cited 9 November 2020]. https://doi.org/10.1007/s00382-012-1636-1

Dunne, J.P., John, J.G., Adcroft, A.J., Griffies, S.M., Hallberg, R.W., Shevliakova, E., Stouffer, R.J. et al. 2012. GFDL's ESM2 global coupled climate-carbon Earth system models. Part I: Physical formulation and baseline simulation characteristics. Journal of Climate, 25(19): 6646-6665 [online]. [Cited 9 November 2020]. https://doi.org/10.1175/JCLI-D-11-00560.1

FAO. 1998. Crop evapotranspiration - Guidelines for computing crop water requirements. FAO Irrigation and Drainage Paper 56. Rome. (also available at http://www.fao.org/3/x0490e/x0490e00.htm).

FAO. 2020a. Modelling System for Agricultural Impacts of Climate Change (MOSAICC) [online]. Rome. [Cited 9 November 2020]. http://www.fao.org/in-action/mosaicc/en/

FAO. 2020b. Analysis and Mapping of Impacts under Climate Change for Adaptation and Food Security (AMICAF) project in Paraguay. Policy brief issued from the AMICAF project.

FAO. 2020c. Evaluación de los impactos del cambio climático en la agricultura en Paraguay. MOSAICC crop component report issued from the AMICAF project. http://www.fao.org/3/ ca6466es/CA6466ES.pdf 
FAO. 2020d. Evaluación de los impactos del cambio climático en la agricultura en Uruguay. MOSAICC crop component report issued from the NAP-Ag programme. http://www.fao.org/3/ ca7134es/CA7134ES.pdf

FAO. 2021. Building climate-smart cropping systems [online]. Rome. [Cited 4 January 2021]. http:// www.fao.org/in-action/save-grow-climate-smart/en/

Fischer, G., Nachtergaele, F., Prieler, S., van Velthuizen, H.T., Verelst, L. \& Wiberg, D. 2008. Global Agro-ecological Zones Assessment for agriculture (GAEZ 2008) [online]. Laxenburg, Austria, IIASA and Rome, FAO. [Cited 9 November 2020]. http://www.fao.org/soils-portal/data-hub/soilmaps-and-databases/harmonized-world-soil-database-v12/en/

Gao, L., Jin, Z., Huang, Y. \& Zhang, L. 1992. Rice clock model - a computer model to simulate rice development. Agricultural and Forest Meteorology, 60(1-2): 1-16 [online]. [Cited 9 November 2020]. https://doi.org/10.1016/0168-1923(92)90071-B

Genovese, G., Bettio, M., Orlandi, S., Boogaard, H.L., Petrakos, M., Stavropoulos, P., Tassoula, I. \& Glossioti, M. 2004. Methodology of the MARS crop yield forecasting system, methodology of the MARS crop yield forecasting system. Vol. 4. statistical data collection, processing and analysis. Luxembourg, EC.

George, E.I. 2000. The variable selection problem. Journal of the American Statistical Association, 95(452): 1304-1308 [online]. [Cited 9 November 2020]. https://doi.org/10.1080/01621459.2000.1047 4336

Guereña, A., Ruiz-Ramos, M., Díaz-Ambrona, C.H., Conde, J.R. \& Mínguez, M.I. 2001. Assessment of climate change and agriculture in Spain using climate models. Agronomy Journal, 93(1): 237-249 [online]. [Cited 9 November 2020]. https://doi.org/10.2134/agronj2001.931237x

Gunasena, H.P.M. 2008. Strategies for increasing food production in Sri Lanka: some suggestions for government's food production drive. Economic Review (Sri Lanka), 34 (7-8): 28-31.

Gutiérrez, J.M., San-Martín, D., Brands, S., Manzanas, R. \& Herrera, S. 2013. Reassessing statistical downscaling techniques for their robust application under climate change conditions. Journal of Climate, 26(1): 171-188 [online]. [Cited 9 November 2020]. https://doi.org/10.1175/JCLI-D-11-00687.1

Hair, J.F., Anderson, R.E., Tatham, R.L. \& Black, W.C. 1995. Multivariate data analysis: with readings, 4 th ed. USA, Prentice-Hall, Inc.

Hasegawa, T., Sakai, H., Tokida, T., Nakamura, H., Zhu, C., Usui, Y., Yoshimoto, M. et al. 2013. Rice cultivar responses to elevated $\mathrm{CO}_{2}$ at two free-air $\mathrm{CO}_{2}$ enrichment (FACE) sites in Japan. 
Functional Plant Biology, 40(2): 148-159 [online]. [Cited 9 November 2020]. https://doi.org/10.1071/ FP12357

Helsel, D.R. \& Hirsch, R.M. 2002. Statistical methods in water resources. Techniques of water resources investigations. Book 4, Chapter A3. Reston, VA, USA, US Geological Survey. 522 pp.

Jungclaus, J.H., Lorenz, S.J., Timmreck, C., Reick, C.H., Brovkin, V., Six, K., Segschneider, J. et al. 2010. Climate and carbon-cycle variability over the last millennium. Climate of the Past, 6: 723737 [online]. [Cited 9 November 2020]. https://doi.org/10.5194/cp-6-723-2010

Karande, B.I., Patel, H.R., Yadav, S.B., Vasani, M.J. \& Patil, D.D. 2018. Impact of projected climate change on summer mungbean in Gujarat. International Journal of Current Microbiology and Applied Sciences, 7(8): 4178-4189. https://doi.org/10.20546/ijcmas.2018.708.437

\section{Kern, A., Barcza, Z., Marjanović, H., Árendás, T., Fodor, N., Bónis, P., Bognár, P. \&}

Lichtenberger, J. 2018. Statistical modelling of crop yield in Central Europe using climate data and remote sensing vegetation indices. Agricultural and Forest Meteorology, 260-261: 300-320 [online]. [Cited 9 November 2020]. https://doi.org/10.1016/j.agrformet.2018.06.009

Kiniry, J.R., Rosenthal, W.D., Jackson, B.S. \& Hoogenboom, G. 1991. Predicting leaf development of crop plants. In T. Hodges, ed. Predicting crop phenology, pp. 29-42. Boca Raton, FL, USA, CRC Press.

Krishnan, P., Swain, D.K., Chandra Bhaskar, B., Nayak, S.K. \& Dash, R.N. 2007. Impact of elevated $\mathrm{CO}_{2}$ and temperature on rice yield and methods of adaptation as evaluated by crop simulation studies. Agriculture Ecosystems \& Environment, 122(2): 233-242 [online]. [Cited 9 November 2020]. https://doi.org/10.1016/j.agee.2007.01.019

Krishnan, P., Ramakrishnan, B., Reddy, K.R. \& Reddy, V.R. 2011. High-temperature effects on rice growth, yield, and grain quality. Advances in Agronomy, 111: 87-206. https://doi.org/10.1016/B9780-12-387689-8.00004-7

Kruse, J.R. 1999. Trend yield analysis and yield growth assumptions. FAPRI-UMC Report No. 06-99. Columbia, USA, Food and Agricultural Policy Research Institute, University of Missouri.

Lange, S. 2016. EartH2Observe, WFDEI and ERA-Interim data Merged and Bias-corrected for ISIMIP (EWEMBI) [online]. GFZ Data Services. [Cited 9 November 2020]. https://doi.org/10.5880/ PIK.2016.004

Li, S., Wheeler, T., Challinor, A., Lin, E., Ju, H. \& Xu, Y. 2010. The observed relationships between wheat and climate in China. Agricultural and Forest Meteorology, 150(11): 1412-1419 [online]. [Cited 9 November 2020]. https://doi.org/10.1016/j.agrformet.2010.07.003 
Lobell, D.B. \& Burke, M.B. 2010. On the use of statistical models to predict crop yield responses to climate change. Agricultural and Forest Meteorology, 150(11): 1443-1452 [online]. [Cited 9 November 2020]. https://doi.org/10.1016/j.agrformet.2010.07.008

Lobell, D.B. \& Field, C.B. 2007. Global scale climate-crop yield relationships and the impacts of recent warming. Environmental Research Letters, 2, 014002 [online]. [Cited 9 November 2020]. https://doi.org/10.1088/1748-9326/2/1/014002

Long, S.P. 1991. Modification of the response of photosynthetic productivity to rising temperature by atmospheric $\mathrm{CO}_{2}$ concentrations: Has its importance been underestimated? Plant, Cell \& Environment, 14(8): 729-739 [online]. [Cited 9 November 2020]. https://doi. org/10.1111/j.1365-3040.1991.tb01439.x

Lorenz, E.N. 1969. Atmospheric predictability as revealed by naturally occurring analogues. Journal of the Atmospheric Sciences, 26(4): 636-646 [online]. [Cited 9 November 2020]. https://doi. org/10.1175/1520-0469(1969)26<636:APARBN>2.0.CO;2

Malaviarachchi, M.A.P.W.K., De Costa, W.A.J.M., Fonseka, R.M., Kumara, J.B.D.A.P., Abhayapala, K.M.R.D. \& Suriyagoda, L.D.B. 2015. Response of maize (Zea mays L.) to a temperature gradient representing long-term climate change under different soil management systems. Tropical Agricultural Research, 25(3): 327-344 [online]. [Cited 9 November 2020]. https:// doi.org/10.4038/tar.v25i3.8043

Malaviarachchi, M.A.P.W.K., De Costa, W.A.J.M., Kumara, J.B.D.A.P., Suriyagoda, L.D.B. \& Fonseka, R.M. 2016. Response of mung bean (Vigna radiata [L.] R. Wilczek) to an increasing natural temperature gradient under different crop management systems. Journal of Agronomy and Crop Science, 202(1): 51-68.

Marambe, B., Punyawardena, R., Silva, P., Premalal, S., Rathnabharathie, V., Kekulandala, B., Nidumolu, U. \& Howden, M. 2015. Climate, climate risk, and food security in Sri Lanka: The need for strengthening adaptation strategies. In W.L. Filho, ed. Handbook of climate change adaptation, pp. 1759-1789. Springer Berlin Heidelberg.

Matthews, R.B., Horie, T., Kropff, M.J., Bachelet, D., Centeno, H.G., Shin, J.C., Mohandass, S., Singh, S., Defeng, Z. \& Lee, M.H. 1995. A regional evaluation of the effect of future climate change on rice production in Asia. In R.B. Matthews, M.J. Kropff, D. Bachelet \& H.H. van Laar, eds. Modeling the impact of climate change on rice production in Asia, pp. 95-139. UK, CAB International.

Mukhala, E. \& Hoefsloot, P. 2004. AgroMetShell manual. Harare, Zimbabwe, SADC Food Security Programme and Rome, Agrometeorology Group, FAO. (also available at http://www.fao.org/3/aau031e.pdf). 
Nguyen, N.V. 2002. Global climate changes and rice food security. Rome, FAO. (also available at http://www.fao.org/forestry/15526-03ecb62366f779d1ed45287e698a44d2e.pdf).

Peng, S., Huang, J., Sheehy, J.E., Laza, R.C., Visperas, R.M., Zhong, X., Centeno, G.S., Khush, G.S. \& Cassman, K.G. 2004. Rice yields decline with higher night temperature from global warming. Proceedings of the National Academy of Sciences, 101(27): 9971-9975 [online]. [Cited 9 November 2020]. https://doi.org/10.1073/pnas.0403720101

Porter, J.R., Xie, L., Challinor, A.J., Cochrane, K., Howden, S.M., Iqbal, M.M., Lobell, D.B. \& Travasso, M.I. 2014. Food security and food production systems. In C.B Field, V.R. Barros, D.J. Dokken, K.J. Mach, M.D. Mastrandrea, T.E. Bilir, M. Chatterjee et al. eds., Climate change, pp. 485533. Cambridge, UK and New York, USA, Cambridge University Press.

Punyawardena, B.V.R. 2002. Identification of the potential of growing seasons by the onset of seasonal rains: a study in the DL region of the north central dry zone. Journal of the National Science Foundation of Sri Lanka, 30(1-2): 13-21 [online]. [Cited 9 November 2020]. http://doi.org/10.4038/ jnsfsr.v30i1-2.2557

Punyawardena, B.V.R., Bandara, T.M.J., Munasinghe, M.A.K., Banda, N.J. \& Pushpakumara, S.M.V. 2003. Agro-ecological regions of Sri Lanka. Peradeniya, Natural Resources Management Centre, Department of Agriculture.

Punyawardena, B.W.R., Dissanaike, T. \& Mallawathanthri, A. 2013. Vulnerability of Sri Lanka to climate change. Monograph. Department of Agriculture, Peradeniya.

Riahi, K., Rao, S., Krey, V., Cho, C., Chirkov, V., Fischer, G., Kindermann, G., Nakicenovic, N. \& Rafaj, P. 2011. RCP 8.5 - A scenario of comparatively high greenhouse gas emissions. Climatic Change, 109: 33 [online]. [Cited 9 November 2020]. https://doi.org/10.1007/s10584-011-0149-y

Santos, J.A., Malheiro, A.C., Karremann, M.K. \& Pinto, J.G. 2010. Statistical modelling of grapevine yield in the Port Wine region under present and future climate conditions. International Journal of Biometeorology, 55: 119-31 [online]. [Cited 9 November 2020]. https://doi.org/10.1007/ s00484-010-0318-0

Sheehy, J.E., Mitchell, P.L. \& Ferrer, A.B. 2006. Decline in rice grain yields with temperature: Models and correlations can give different estimates. Field Crops Research, 98(2-3): 151-156 [online]. [Cited 9 November 2020]. https://doi.org/10.1016/j.fcr.2006.01.001

Shi, W., Tao, F. \& Zhang, Z. 2013. A review on statistical models for identifying climate contributions to crop yields. Journal of Geographical Sciences, 23: 567-576 [online]. [Cited 9 November 2020]. https://doi.org/10.1007/s11442-013-1029-3 
Tanaka, I. 1976. Climatic influence on photosynthesis and respiration of rice. In Proceedings of the Symposium on Climate and Rice, pp. 223-247. International Rice Research Institute, Philippines.

Tao, F. \& Zhang, Z. 2011. Impacts of climate change as a function of global mean temperature: maize productivity and water use in China. Climatic Change, 105: 409-432 [online]. [Cited 9 November 2020]. https://doi.org/10.1007/s10584-010-9883-9

Taylor, K.E., Stouffer, R.J. \& Meehl, G.A. 2012. An overview of CMIP5 and the experiment design. Bulletin of the American Meteorological Society, 93(4): 485-498 [online]. [Cited 9 November 2020]. https://doi.org/10.1175/BAMS-D-11-00094.1

Thomson, A.M., Calvin, K.V., Smith, S.J., Kyle, G.P., Volke, A., Patel, P., Delgado-Arias, S. et al. 2011. RCP4.5: a pathway for stabilization of radiative forcing by 2100. Climatic Change, 109: 77 [online]. [Cited 9 November 2020]. https://doi.org/10.1007/s10584-011-0151-4

Titumil, R.A.M. \& Basak, J.K. 2010. Agriculture and food security in South Asia. A historical analysis and a long run perspective. Dhaka, Bangladesh, The Innovators.

van Oort, P.A.J. \& Zwart, S.J. 2018. Impacts of climate change on rice production in Africa and causes of simulated yield changes. Global Change Biology, 24(3): 1029-1045 [online]. [Cited 9 November 2020]. https://doi.org/10.1111/gcb.13967

van der Velde, M. \& Nisini, L. 2019. Performance of the MARS-crop yield forecasting system for the European Union: Assessing accuracy, in-season, and year-to-year improvements from 1993 to 2015. Agricultural Systems, 168: 203-212 [online]. [Cited 9 November 2020]. https://doi.org/10.1016/j. agsy.2018.06.009

Venables, W.N. \& Ripley, B.D. 2002. Modern applied statistics with S. 4th ed. New York, SpringerVerlag.

Vogel, E., Donat, M.G., Alexander, L.V., Meinshausen, M., Ray, D.K., Karoly, D., Meinshausen, N. \& Frieler, K. 2019. The effects of climate extremes on global agricultural yields. Environmental Research Letters, 14(5): 054010 [online]. [Cited 9 November 2020]. https://doi.org/10.1088/17489326/ab154b

Voldoire, A., Sanchez-Gomez, E., Salas y Mélia, D., Decharme, B., Cassou, C., Sénési, S., Valcke, S. et al. 2013. The CNRM-CM5.1 global climate model: description and basic evaluation. Climate Dynamics, 40: 2091-2121 [online]. [Cited 9 November 2020]. https://doi.org/10.1007/s00382-011-1259-y

Watanabe, S., Hajima, T., Sudo, K., Nagashima, T., Takemura, T., Okajima, H., Nozawa, T. et al. 2011. MIROC-ESM 2010: model description and basic results of CMIP5-20c3m experiments. 
Geoscientific Model Development, 4: 845-872 [online]. [Cited 9 November 2020]. https://doi. org/10.5194/gmd-4-845-2011

Weerakoon, W.M.W. 2013. Impacts of climate change on food security in Sri Lanka. In Proceedings of the International Conference on Climate Change Impacts and Adaptation, Coconut Research Institute of Sri Lanka, Lunuwila, Sri Lanka.

Weerakoon, W.M.W., Maruyama, A. \& Ohba, K. 2008. Impact of humidity on temperatureinduced grain sterility in rice (Oryza sativa L). Journal of Agronomy and Crop Science, 194(2): 135140 [online]. [Cited 9 November 2020]. https://doi.org/10.1111/j.1439-037X.2008.00293.x

Wellek, S. 2010. Testing statistical hypotheses of equivalence and noninferiority. 2nd edition. Boca Raton, FL, USA, Chapman \& Hall/CRC.

Yao, F., Qin, P., Zhang, J., Lin, E. \& Boken, V. 2011. Uncertainties in assessing the effect of climate change on agriculture using model simulation and uncertainty processing methods. Chinese Science Bulletin, 56: 729-737 [online]. [Cited 9 November 2020]. https://doi.org/10.1007/s11434-011-4374-6

Ye, T., Nie, J., Wang, J., Shi, P. \& Wang, Z. 2014. Performance of detrending models of crop yield risk assessment: evaluation on real and hypothetical yield data. Stochastic Environmental Research and Risk Assessment, 29: 109-117 [online]. [Cited 9 November 2020]. https://doi.org/10.1007/ s00477-014-0871-x

Yoshida, S. 1978. Tropical climate and its influence on rice. IRRI Research Paper Series 20. Los Baños, Philippines, International Rice Research Institute.

Zorita, E., Hughes, J.P., Lettemaier, D.P. \& von Storch, H. 1995. Stochastic characterization of regional circulation patterns for climate model diagnosis and estimation of local precipitation. Journal of Climate, 8(5): 1023-1042 [online]. [Cited 9 November 2020]. https://doi. org/10.1175/1520-0442(1995)008<1023:SCORCP $>2.0$. CO;2

Zubair, L., Nissanka, S.P., Weerakoon, W.M.W., Herath, D.I., Karunaratne, A.S., Prabodha, A.S.M., Agalawatte, M.B. et al. 2015. Climate change impacts on rice farming systems in northwestern Sri Lanka. In C. Rosenzweig \& D. Hillel, eds. Handbook of climate change and agroecosystems, pp. 315-352. ICP Series on Climate Change Impacts, Adaptation, and Mitigation Vol. 3. Imperial College Press. 


\section{Appendix}

Moneragala

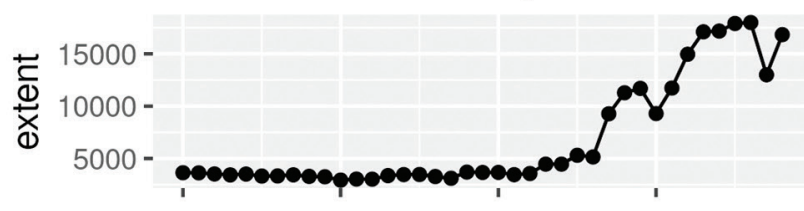

Kurunegala

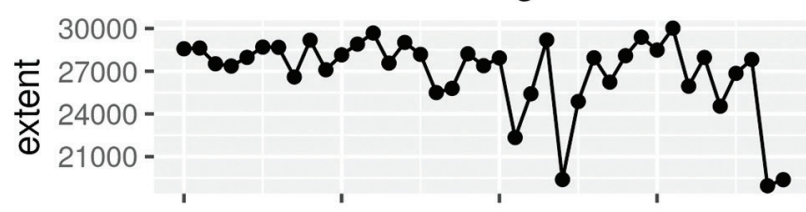

Galle

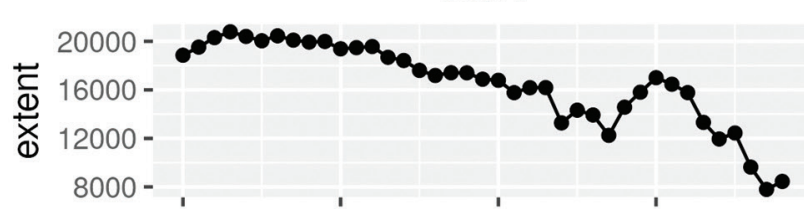

Anuradhapura

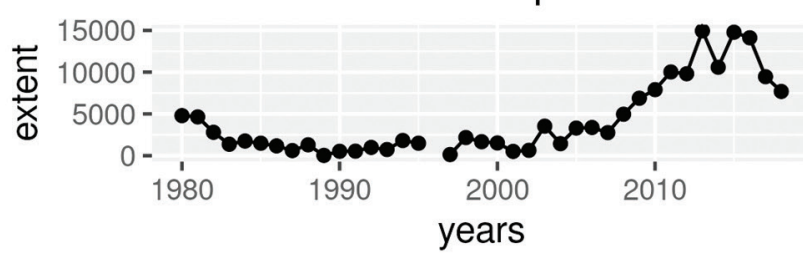

Batticaloa

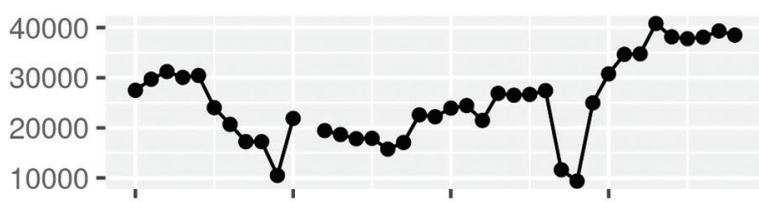

Ampara

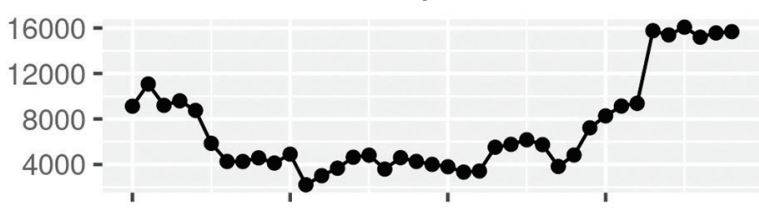

Kilinochchi

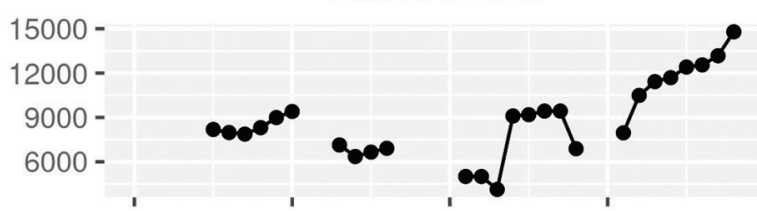

Kalutara

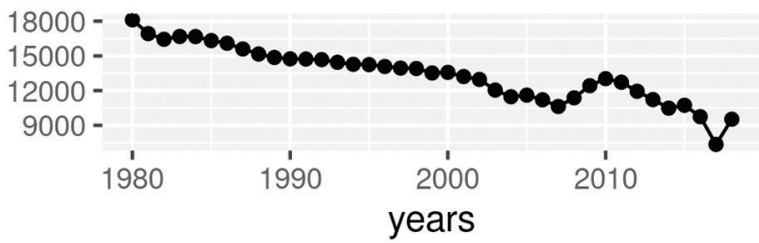

Figure A1. Rice cultivatd extent (ha) - Maha season - Rainfed 
Ampara

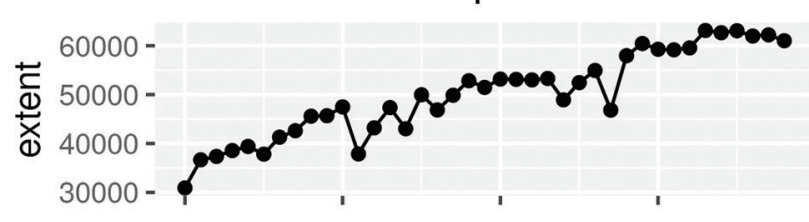

Polonnaruwa

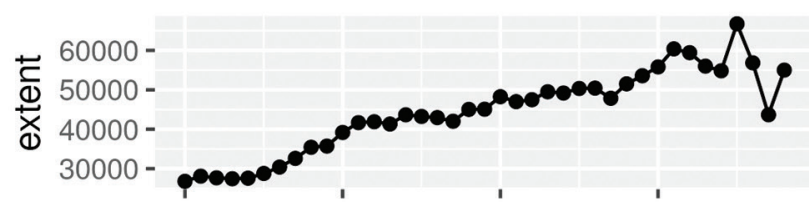

Batticaloa

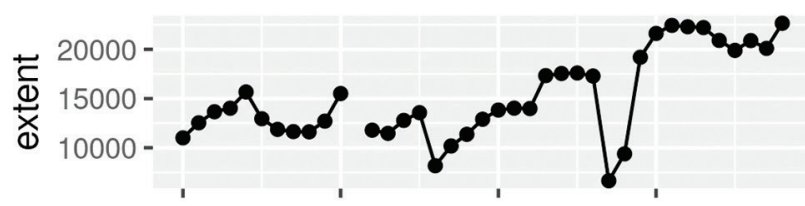

Hambantota

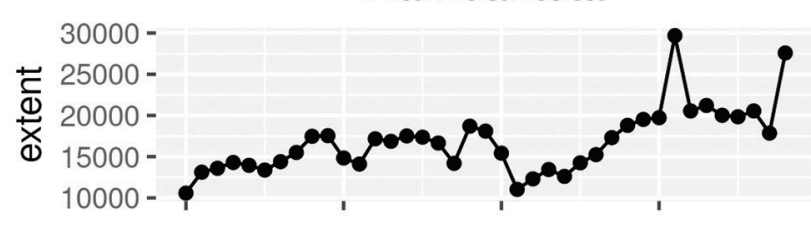

Trincomalee

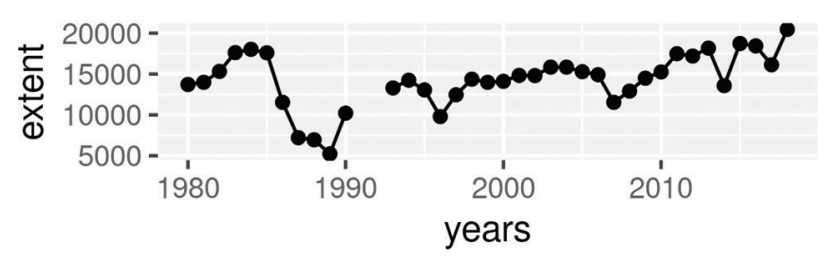

Anuradhapura

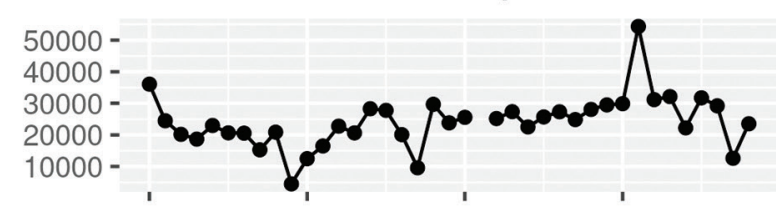

Kurunegala

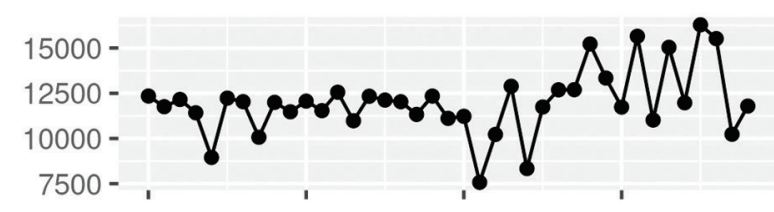

Mannar

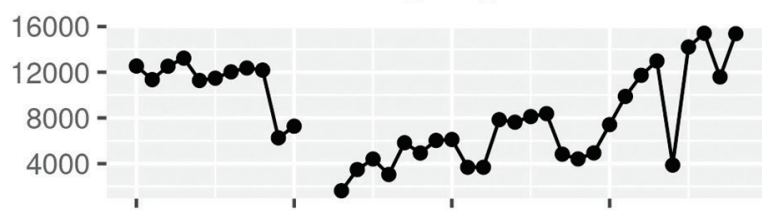

Badulla

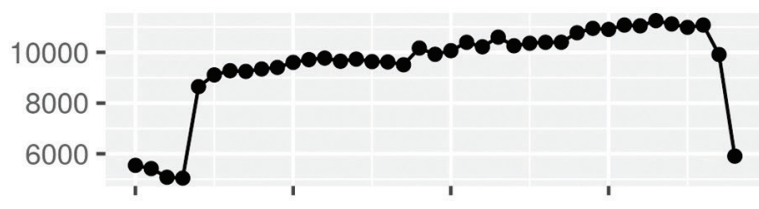

Kilinochchi

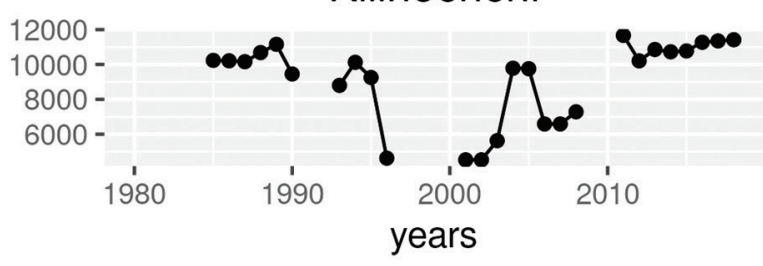

Figure A2. Rice cultivated area (ha) - Maha season - Irrigated 
Ampara

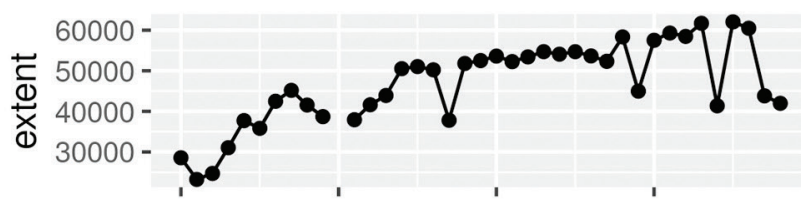

Anuradhapura

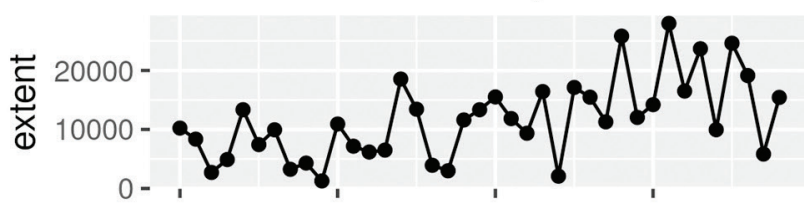

Kurunegala

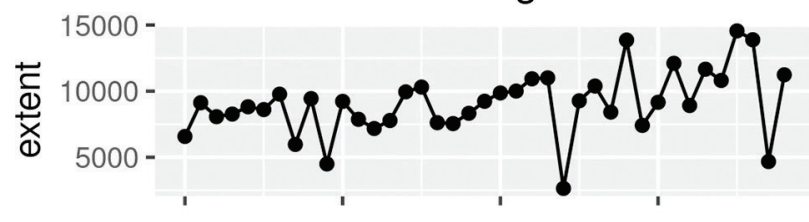

Trincomalee

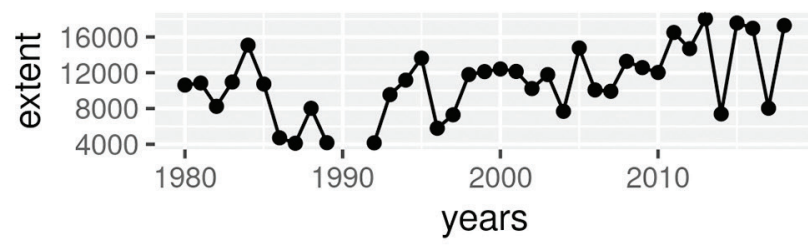

Batticaloa

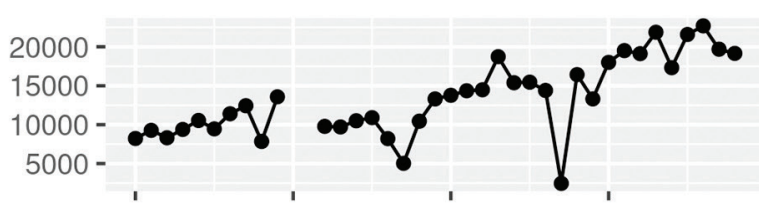

Polonnaruwa

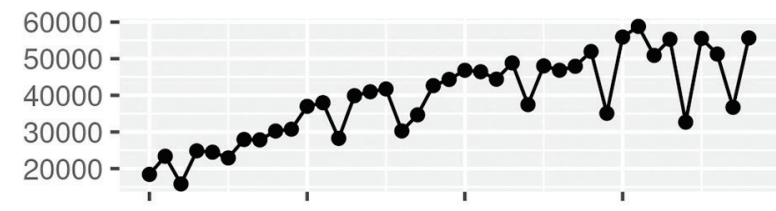

Hambantota

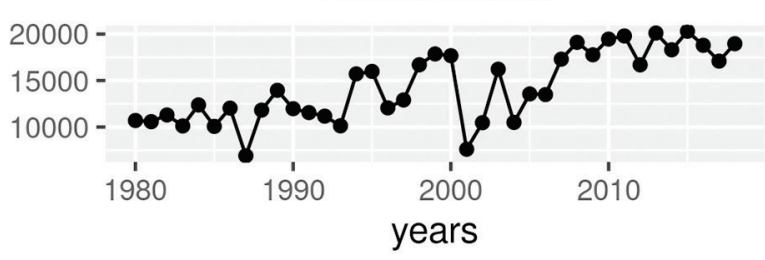

Figure A3. Rice cultivated area (ha) - Yala season - irrigated 
Moneragala

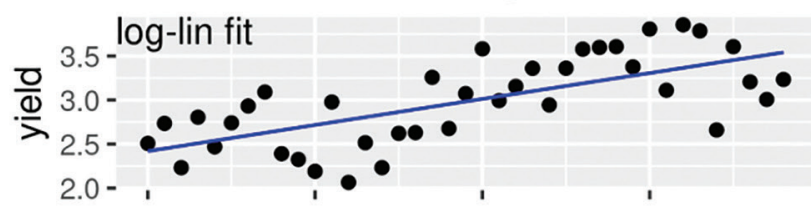

Kurunegala

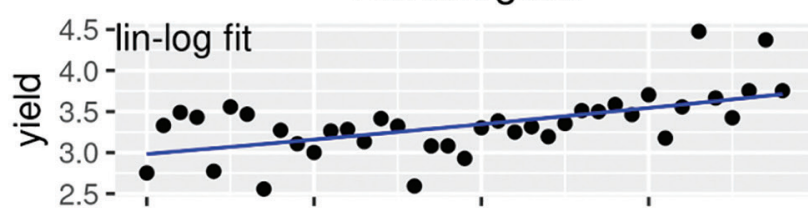

Galle

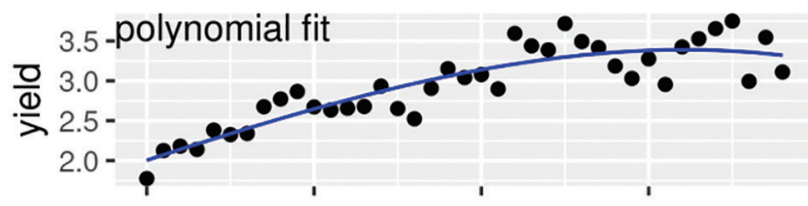

Anuradhapura

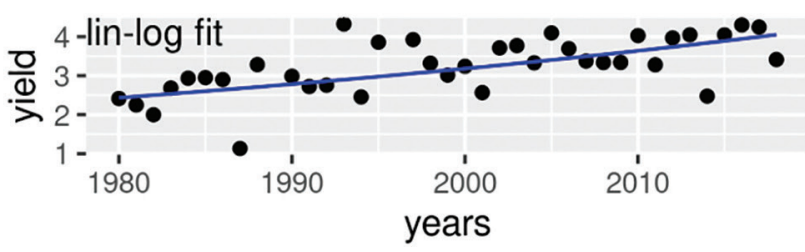

Batticaloa

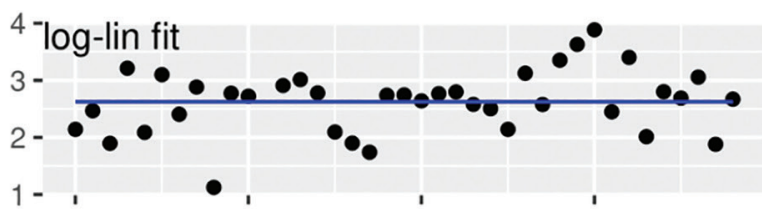

Ampara

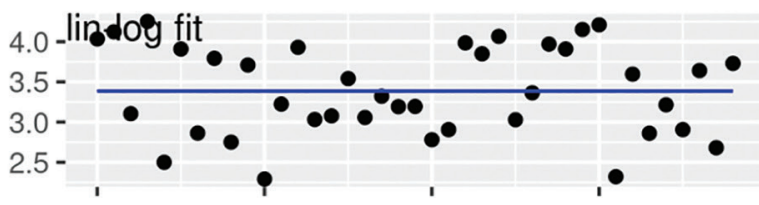

Kilinochchi

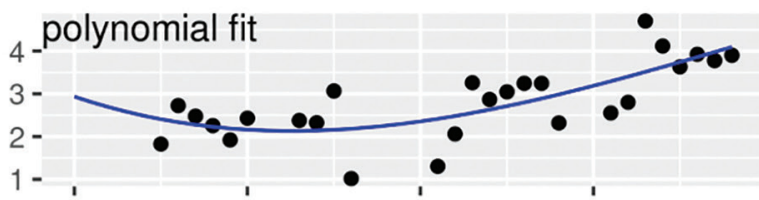

Kalutara

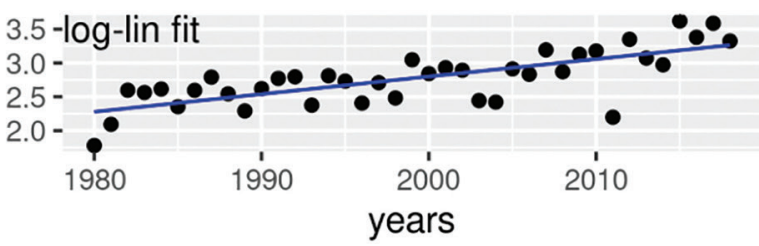

Figure A4. Rice yield and trend line (t/ha) - Maha season - Rainfed 
Ampara

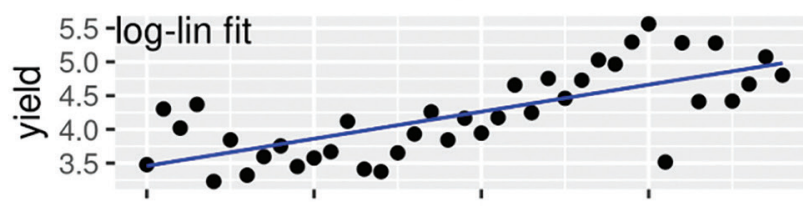

Polonnaruwa

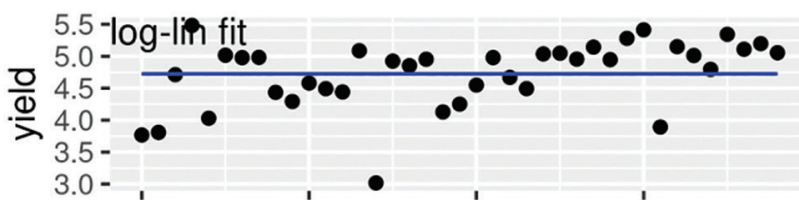

Batticaloa

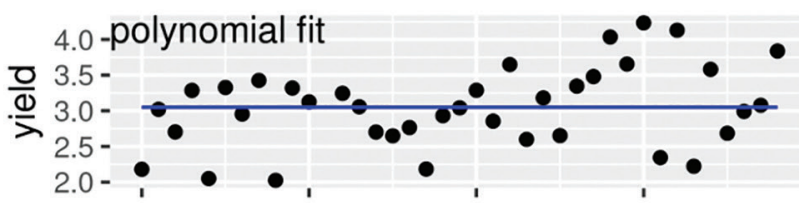

Hambantota

7 -polynomial fit

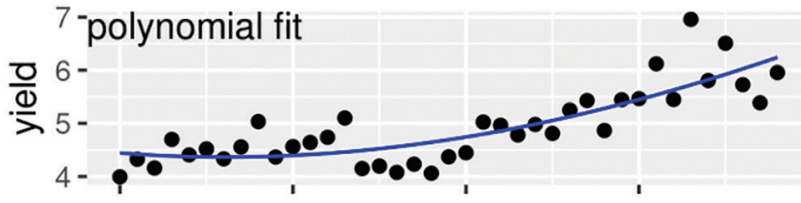

Trincomalee

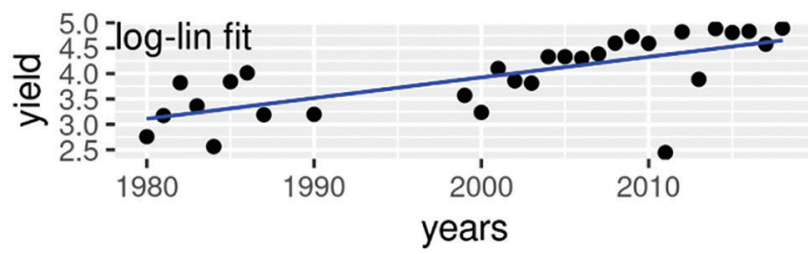

Anuradhapura

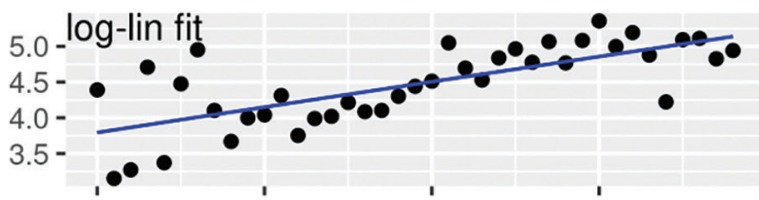

Kurunegala

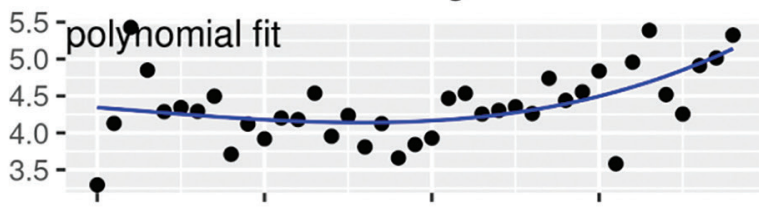

Mannar

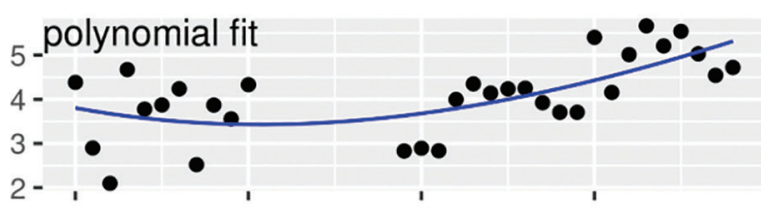

Badulla

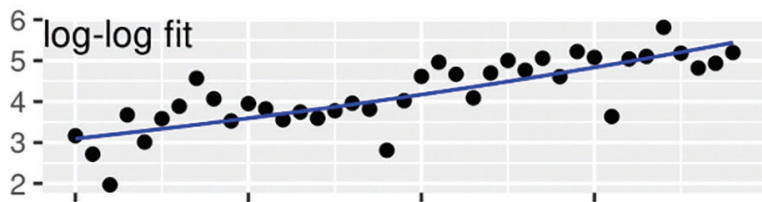

Kilinochchi

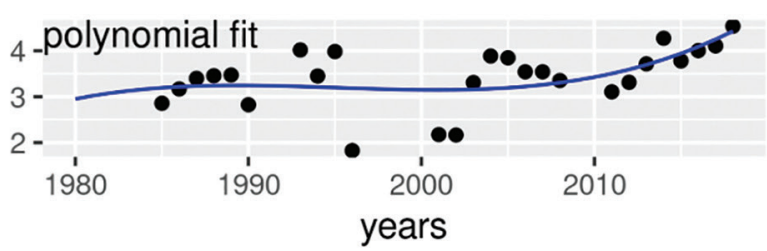

Figure A5. Rice yield and trend line (t/ha) - Maha season - Irrigated 
Ampara

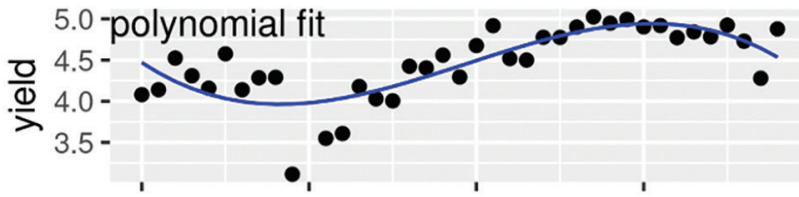

Anuradhapura

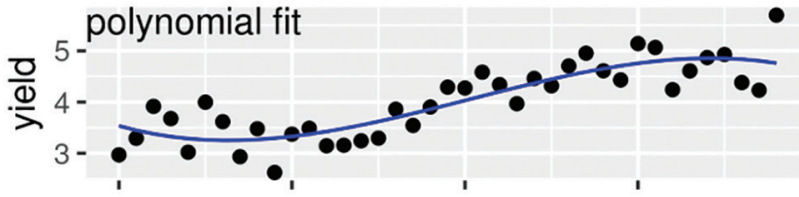

Kurunegala

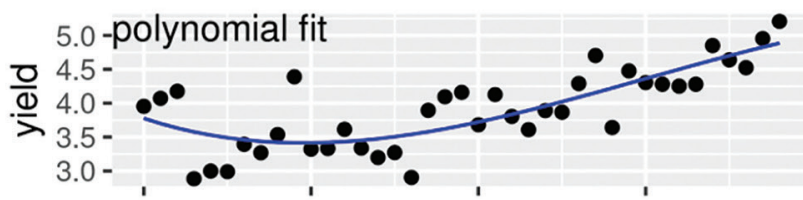

Trincomalee

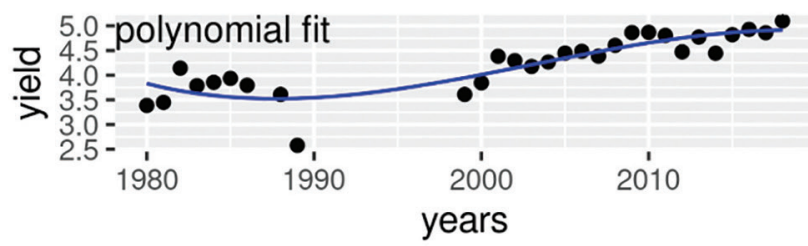

Batticaloa

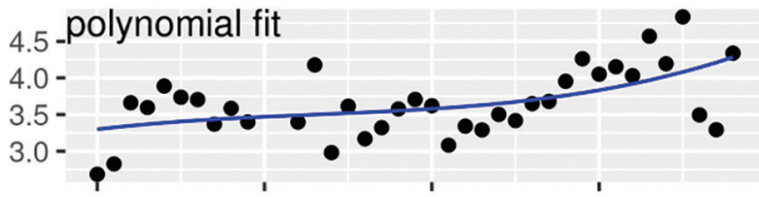

Polonnaruwa

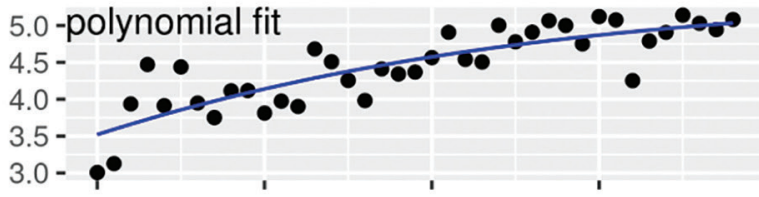

Hambantota

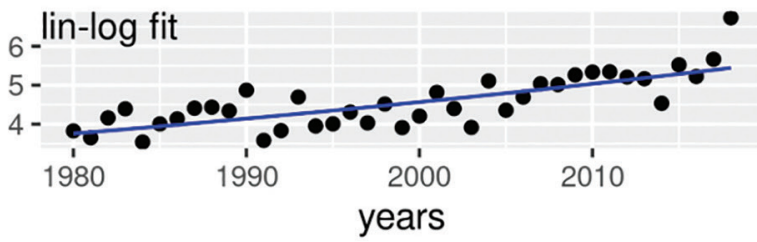

Figure A6. Rice yield and trend line (t/ha) - Yala season - Irrigated 
Moneragala

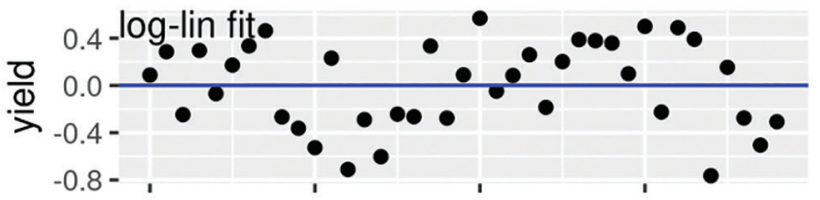

Kurunegala

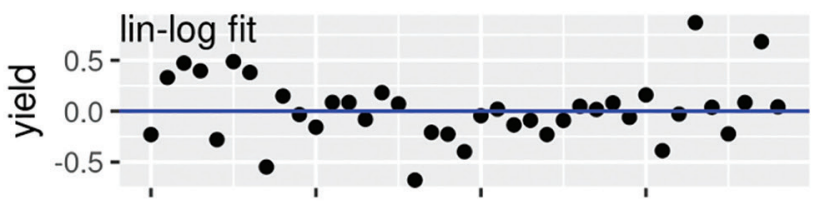

Galle

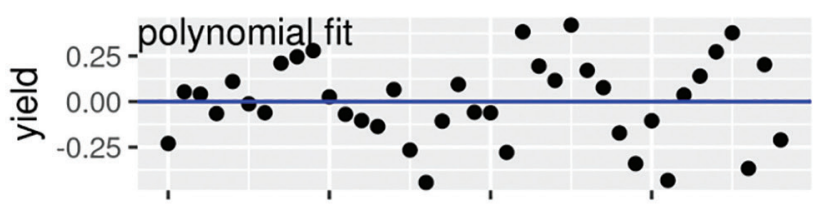

Anuradhapura

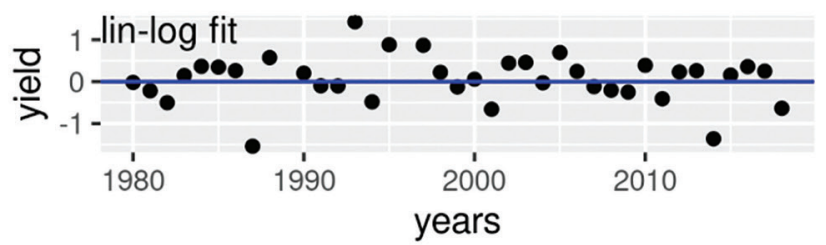

Batticaloa

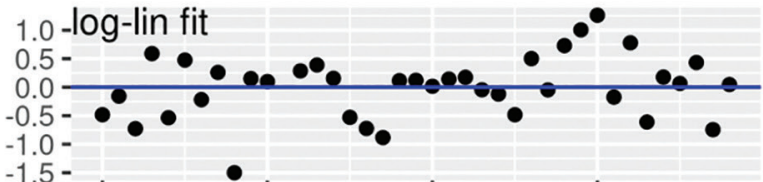

Ampara

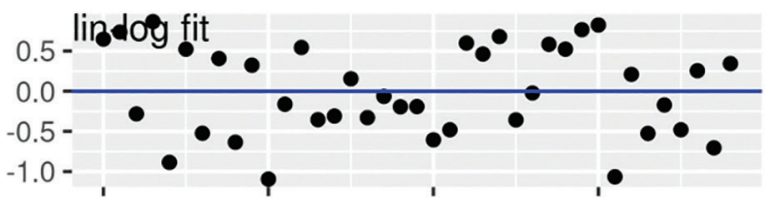

Kilinochchi

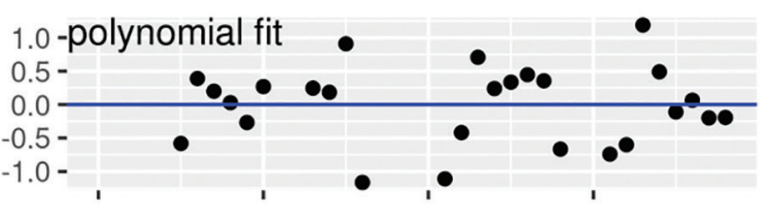

Kalutara

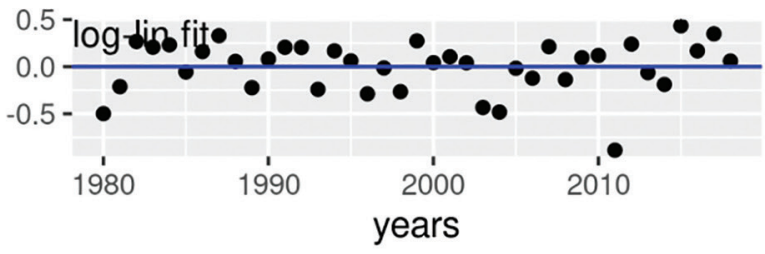

Figure A7. Rice yield anomaly (t/ha) - Maha season - Rainfed 
Ampara

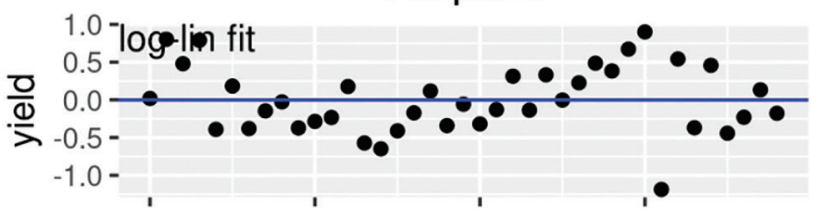

Polonnaruwa

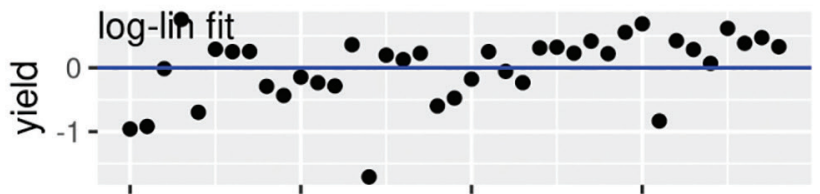

Batticaloa

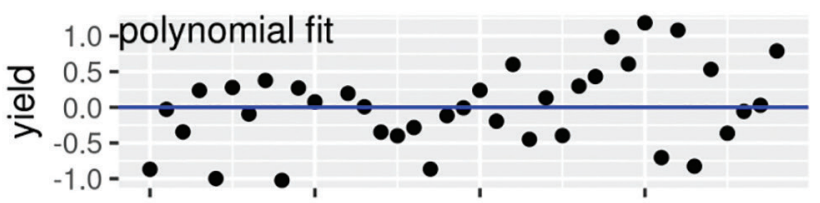

Hambantota

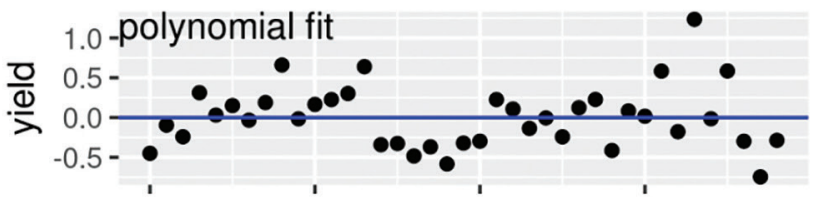

Trincomalee

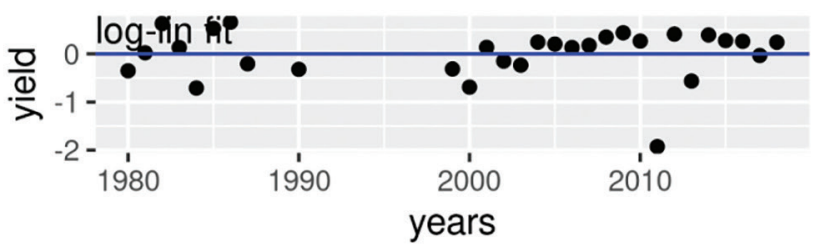

Anuradhapura

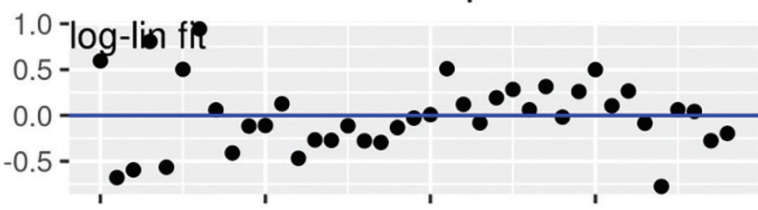

Kurunegala

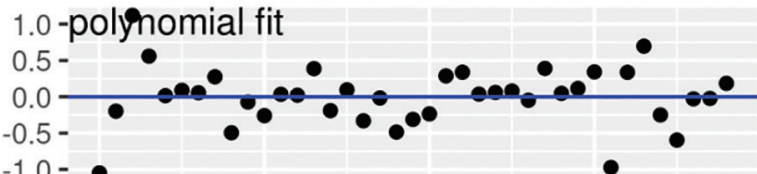

Mannar

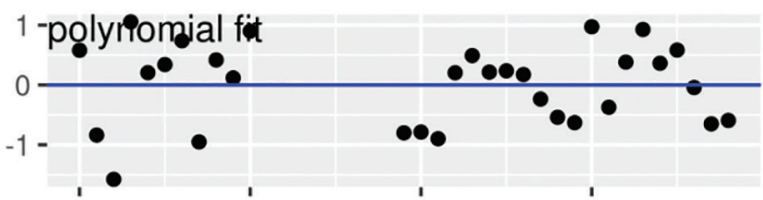

Badulla

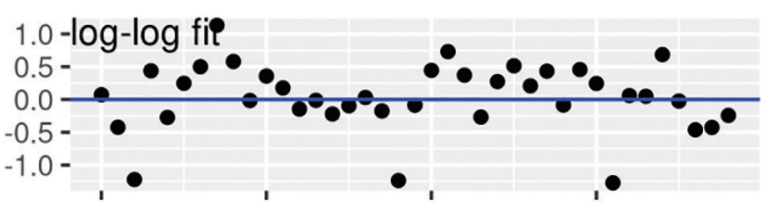

Kilinochchi

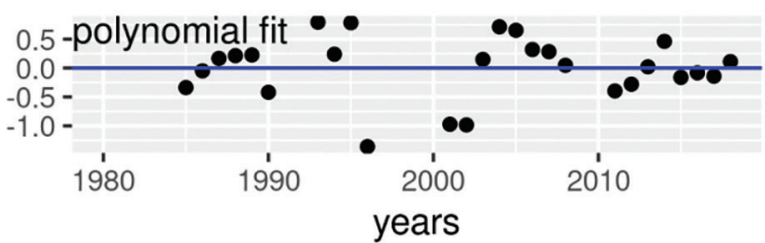

Figure A8. Rice yield anomaly (t/ha) - Maha season - Irrigated 
Ampara

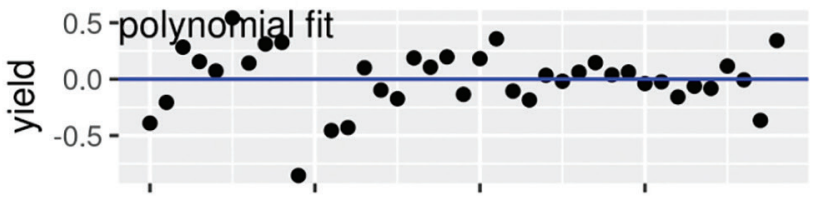

Anuradhapura

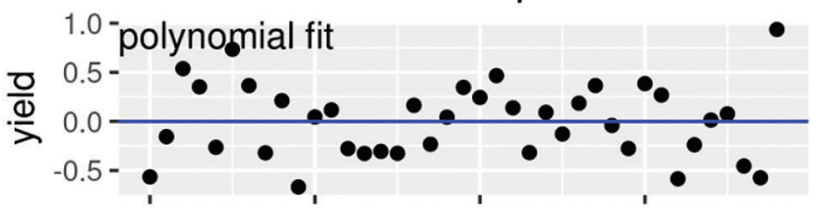

Kurunegala

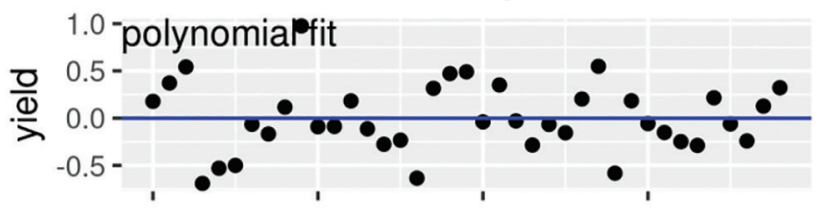

Trincomalee

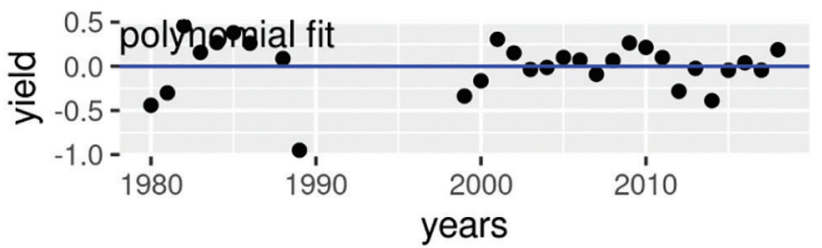

Batticaloa

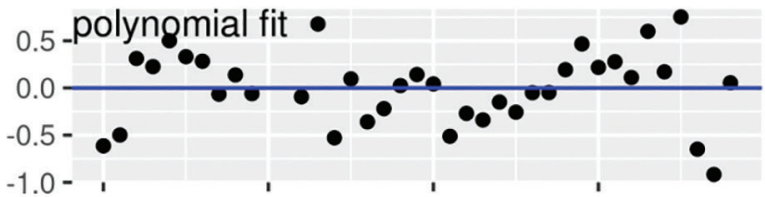

Polonnaruwa

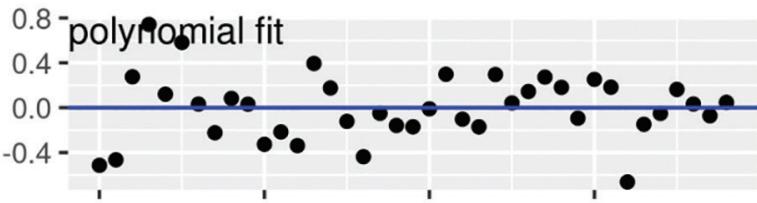

Hambantota

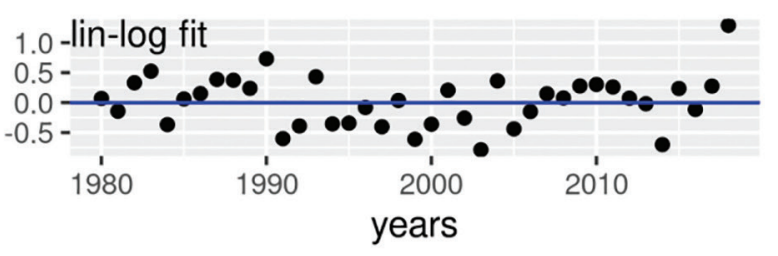

Figure A9. Rice yield anomaly (t/ha) - Yala season - Irrigated 
Anuradhapura

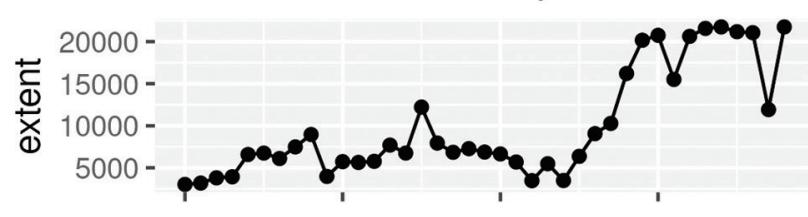

Moneragala

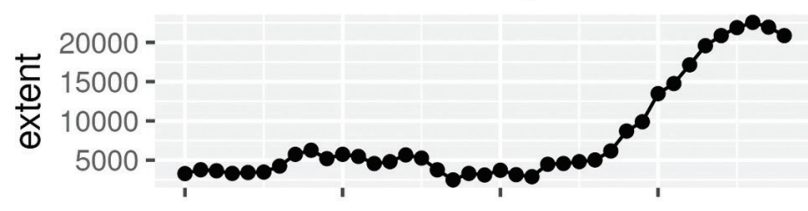

Trincomalee

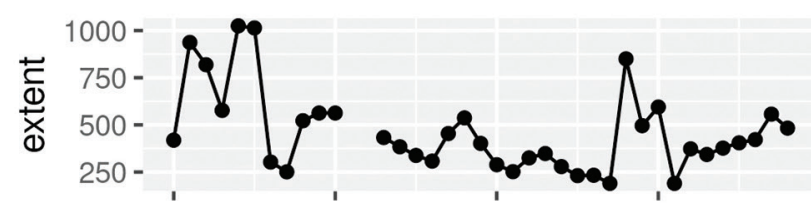

Hambantota

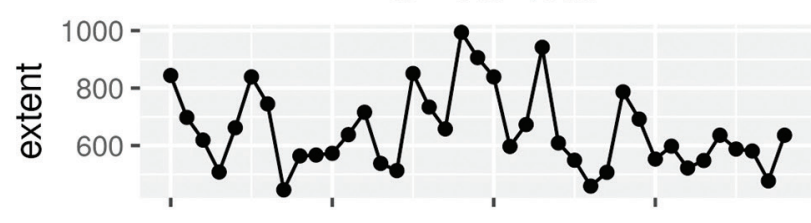

Polonnaruwa

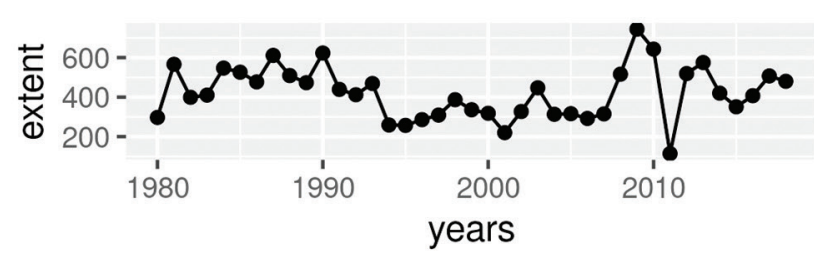

Ampara

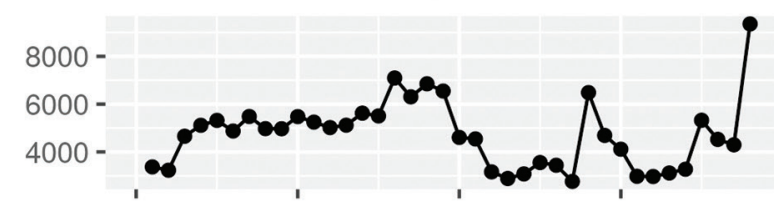

Badulla

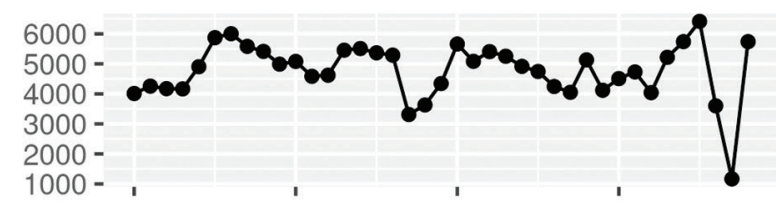

Kurunegala

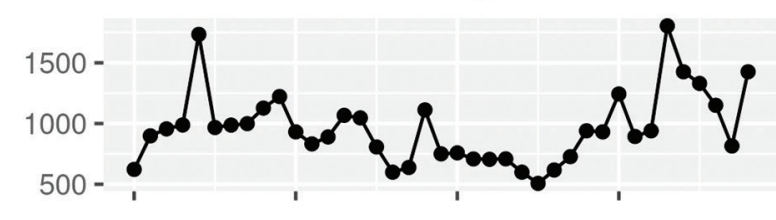

Batticaloa

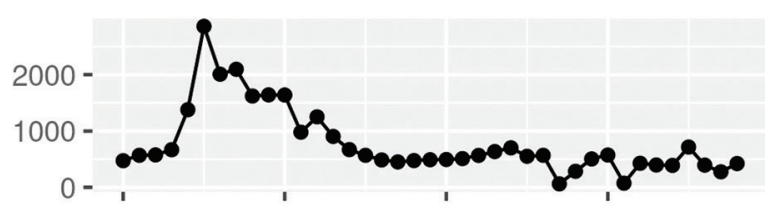

Puttalam

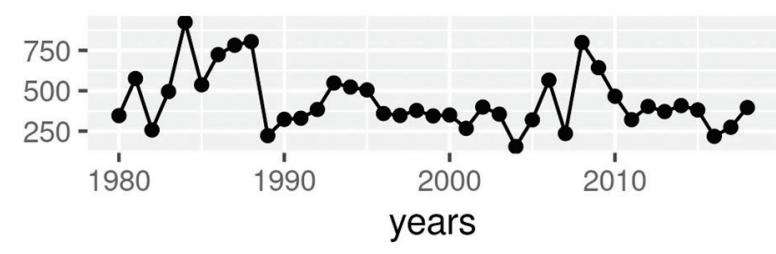

Figure A10. Maize cultivated area (t/ha) - Maha season - Irrigated 
Badulla

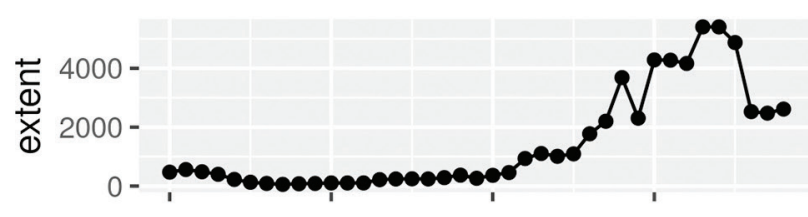

Kurunegala

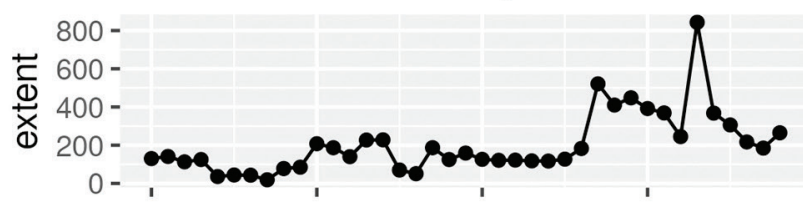

Polonnaruwa

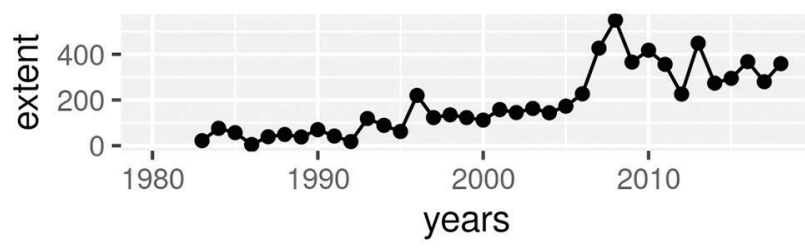

Anuradhapura

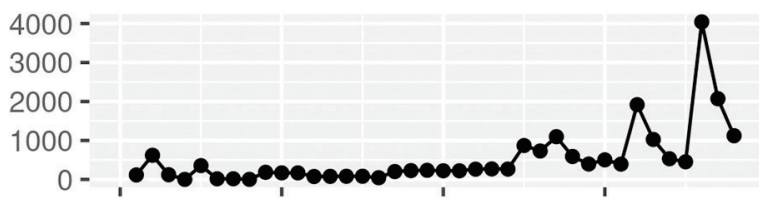

Moneragala

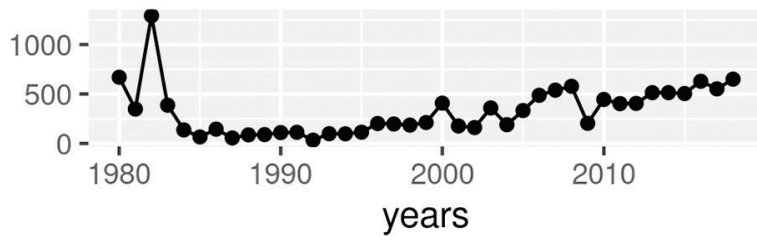

Figure A11. Maize cultivated area (ha)- Yala season - Irrigated 
Anuradhapura

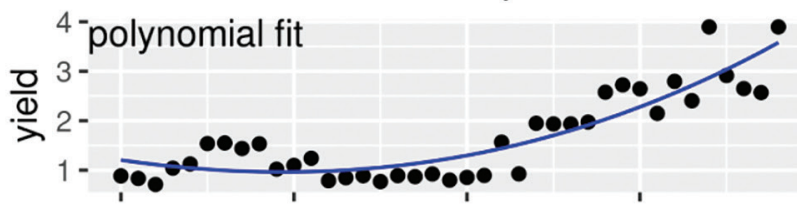

Moneragala

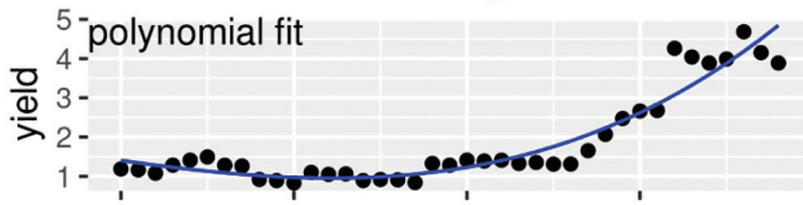

Trincomalee

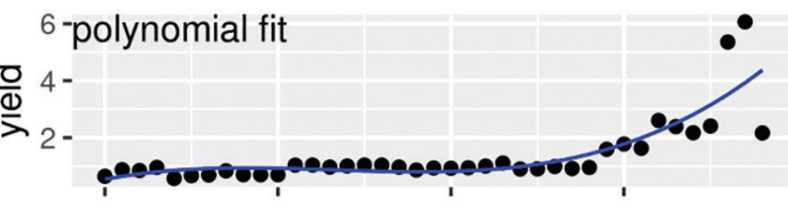

\section{Hambantota}

2.5 -polynomial fit

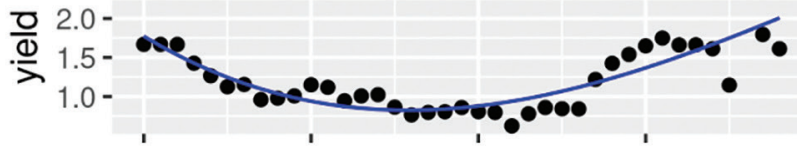

Polonnaruwa

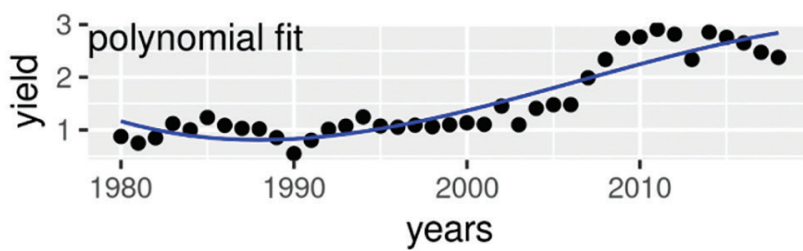

Ampara

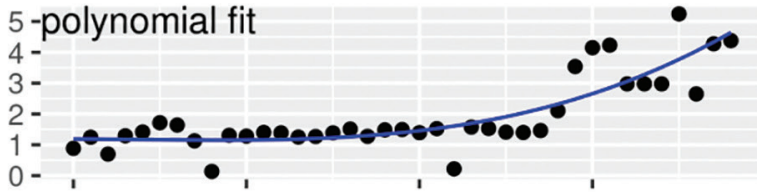

Badulla

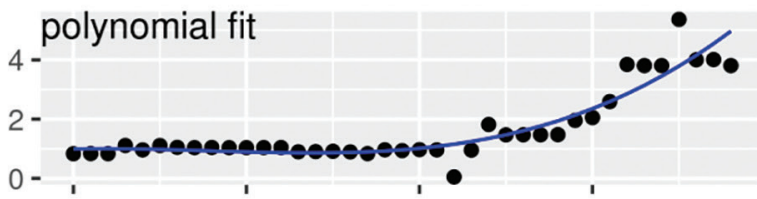

Kurunegala

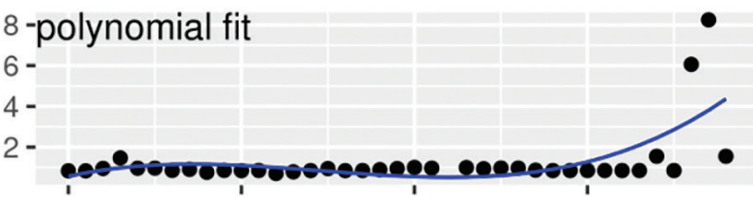

Batticaloa

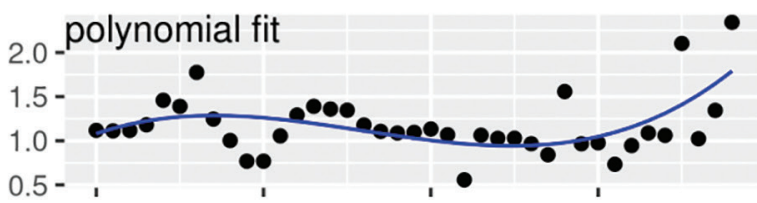

Puttalam

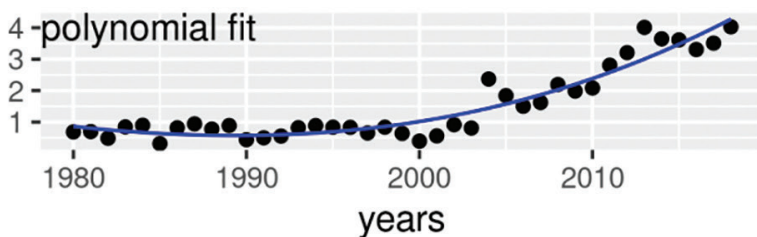

Figure A12. Maize yield and trend line (t/ha) - Maha season - Irrigated 
Badulla

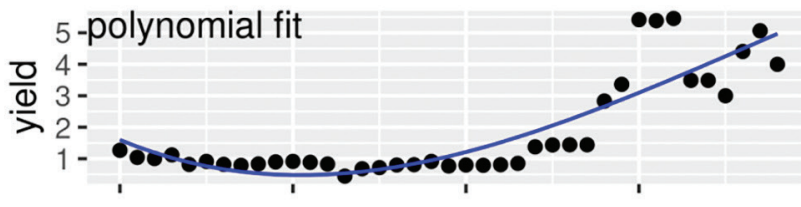

Kurunegala

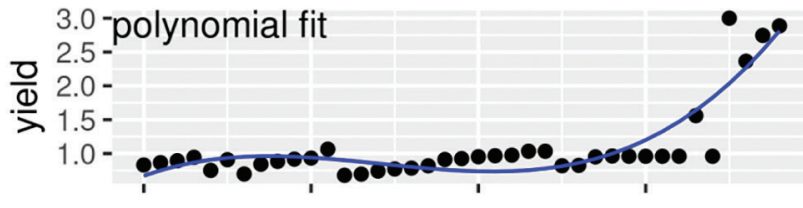

\section{Polonnaruwa}

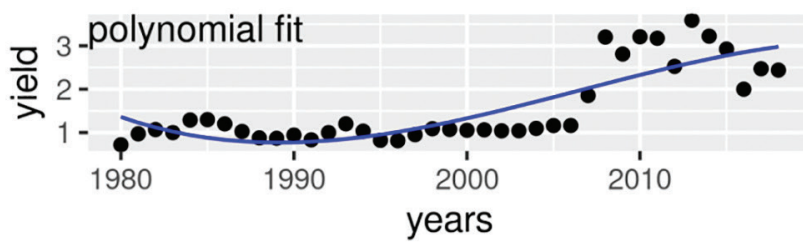

Anuradhapura

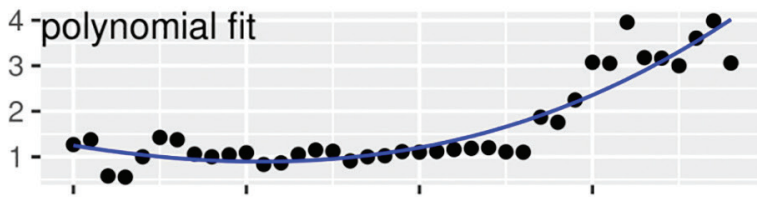

Moneragala

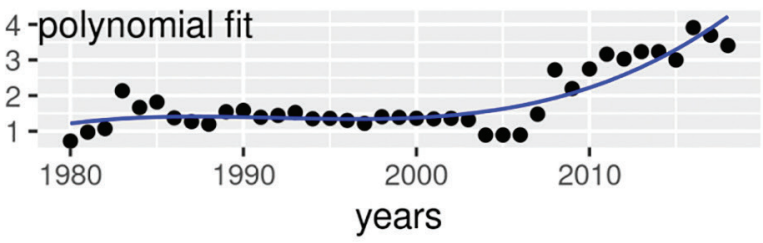

Figure A13. Maize yield and trend line (t/ha) - Yala season - Irrigated 
Anuradhapura

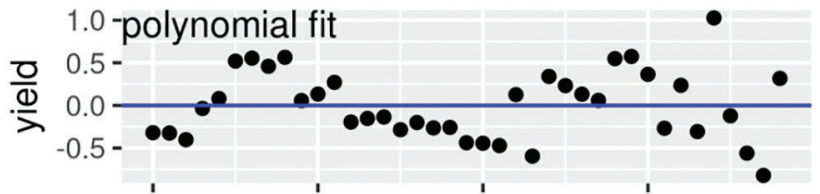

Moneragala

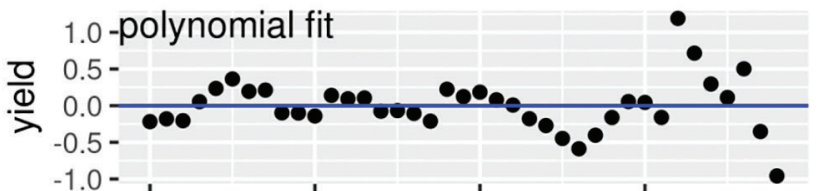

Trincomalee

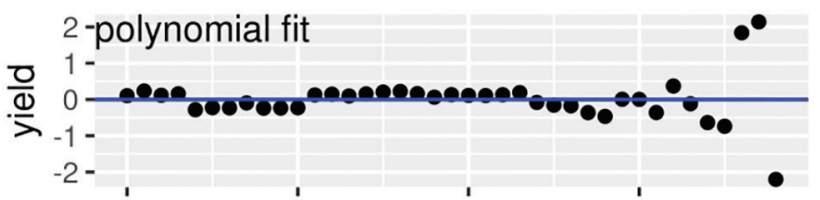

Hambantota

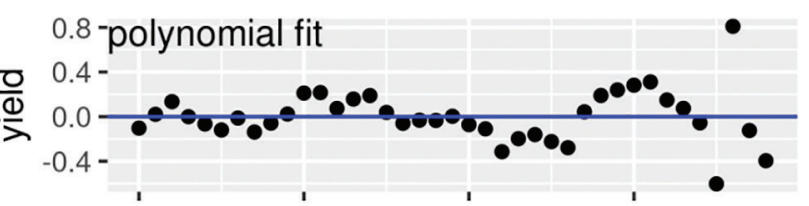

Polonnaruwa

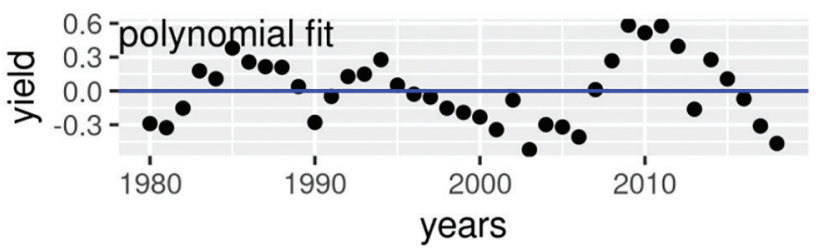

Ampara

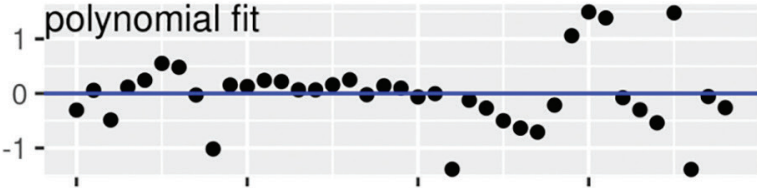

Badulla

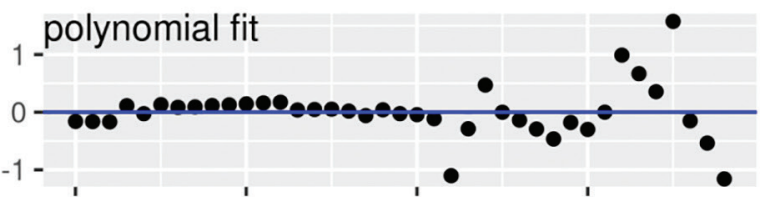

Kurunegala

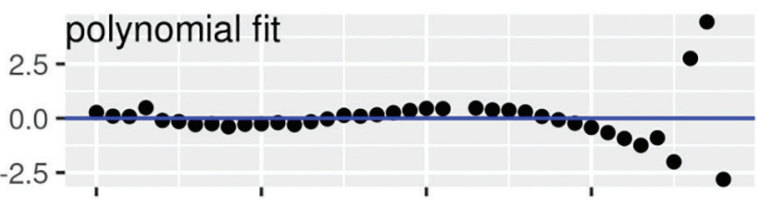

Batticaloa

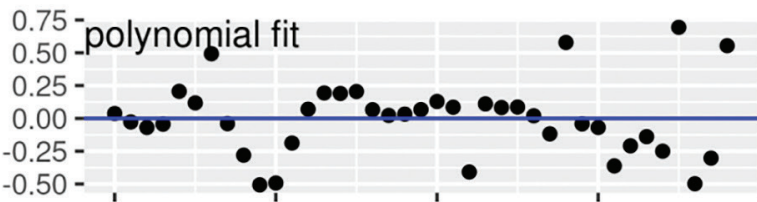

Puttalam

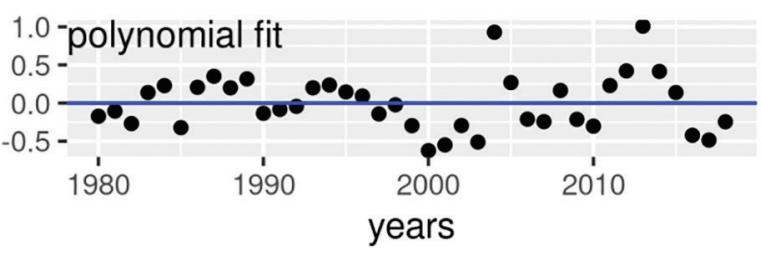

Figure A14. Maize yield anomaly (t/ha) - Maha season - Irrigated 
Badulla

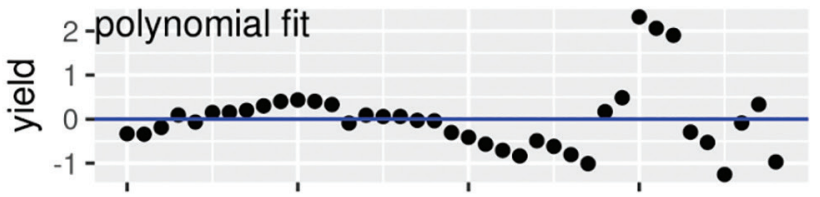

Kurunegala

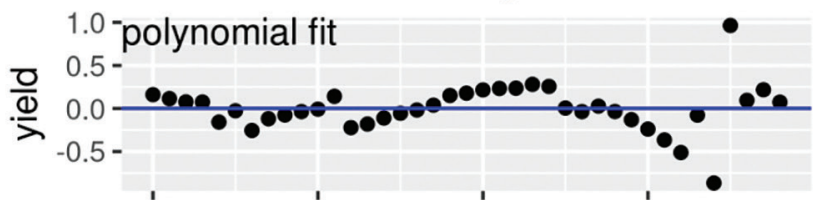

Polonnaruwa

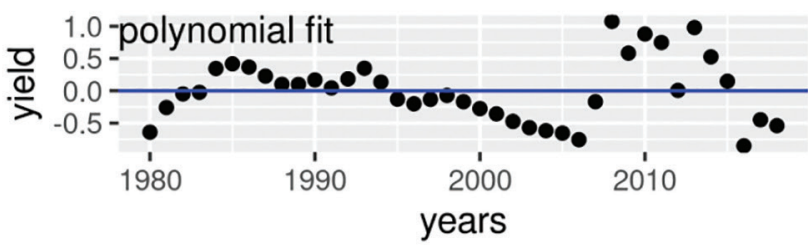

Anuradhapura

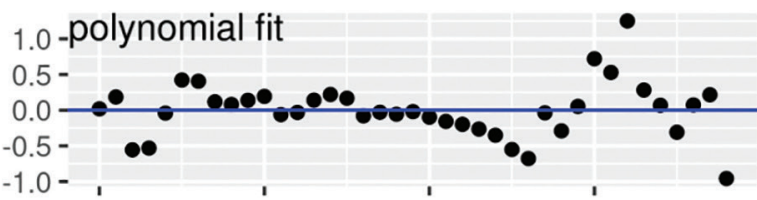

Moneragala

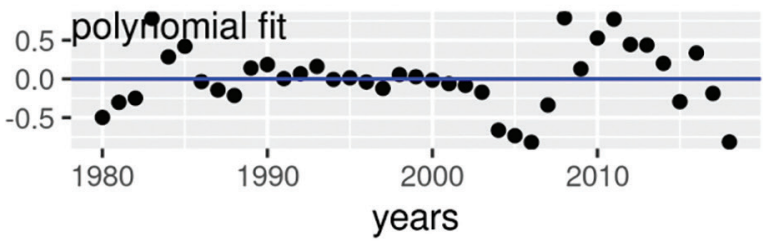

Figure A15. Maize yield anomaly (t/ha) - Yala season - Irrigated

Matale

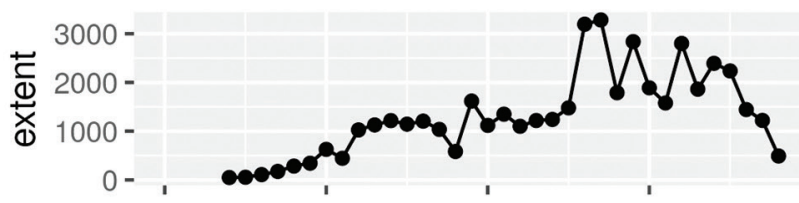

Polonnaruwa

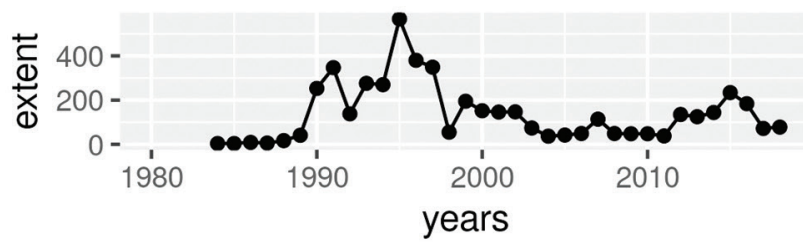

Anuradhapura

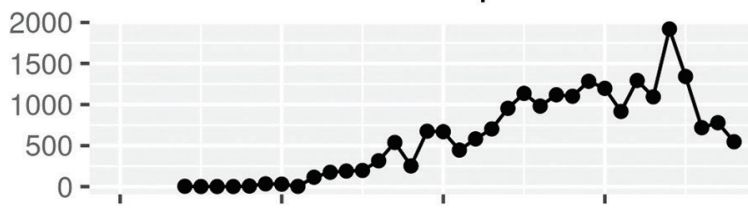

Kurunegala

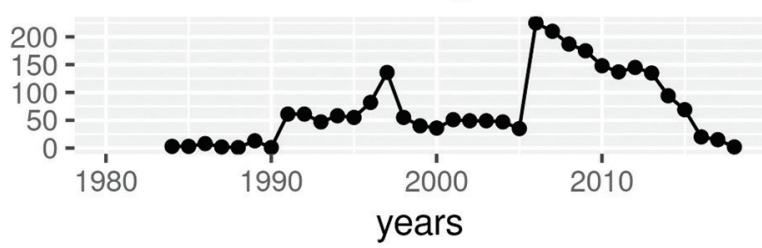

Figure A16. Big onion cultivated area (ha) - Yala season - Irrigated 
Matale

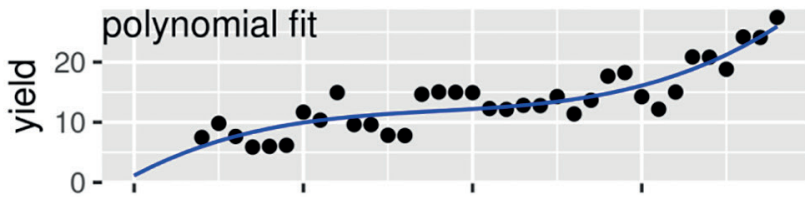

Polonnaruwa

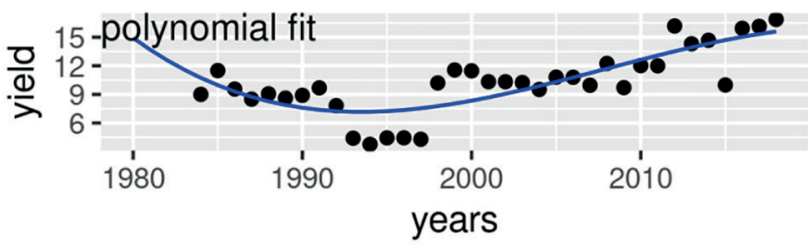

Anuradhapura

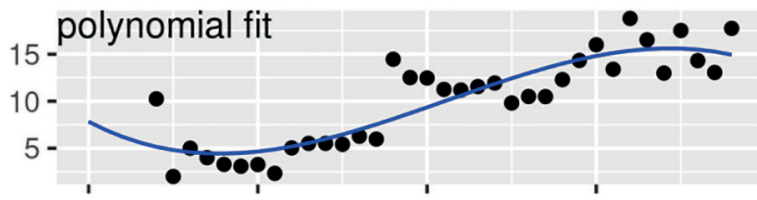

Kurunegala

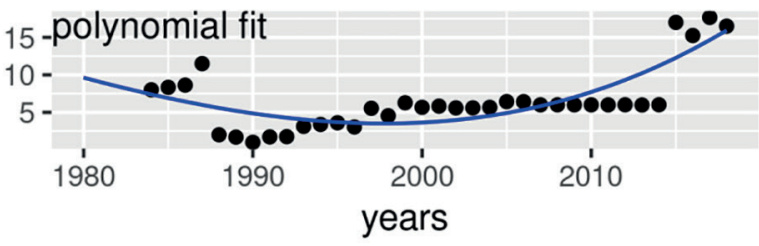

Figure A17. Big onion yield and trend line (t/ha) - Yala season - Irrigated

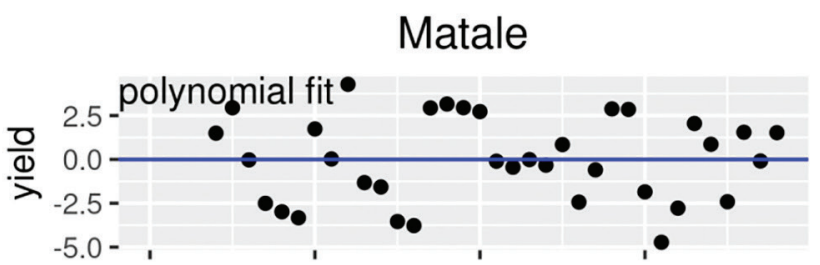

Anuradhapura

Polonnaruwa

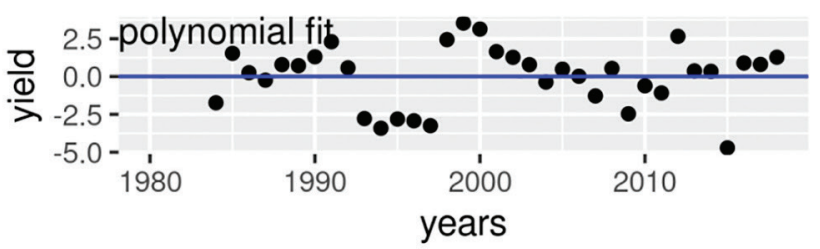

Kurunegala

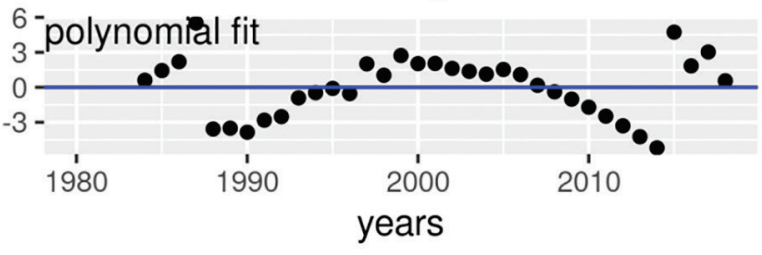

Figure A18. Big onion yield anomaly (t/ha) - Yala season - irrigated 

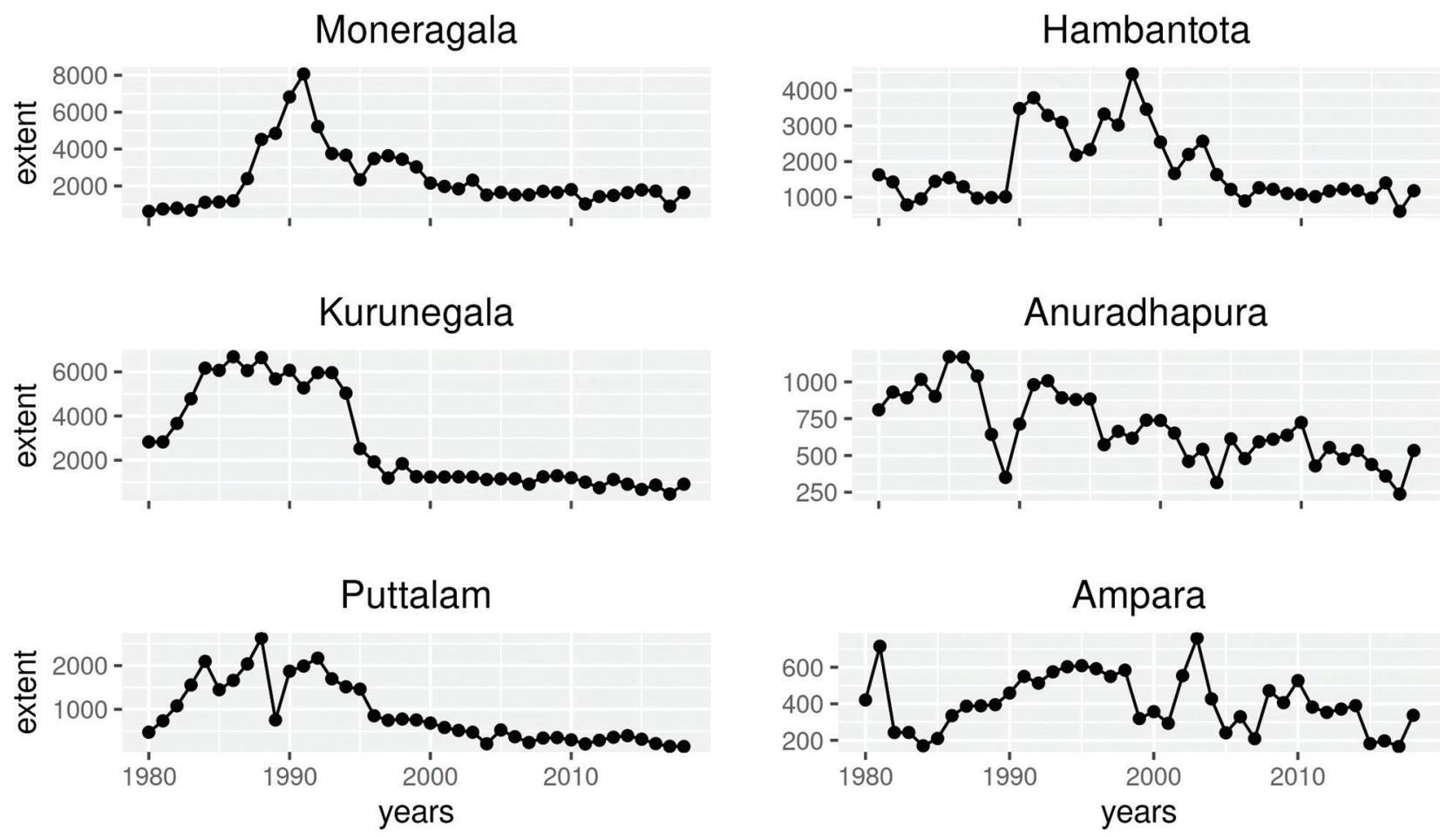

Figure A19. Green gram cultivated area (ha) - Maha season - Irrigated
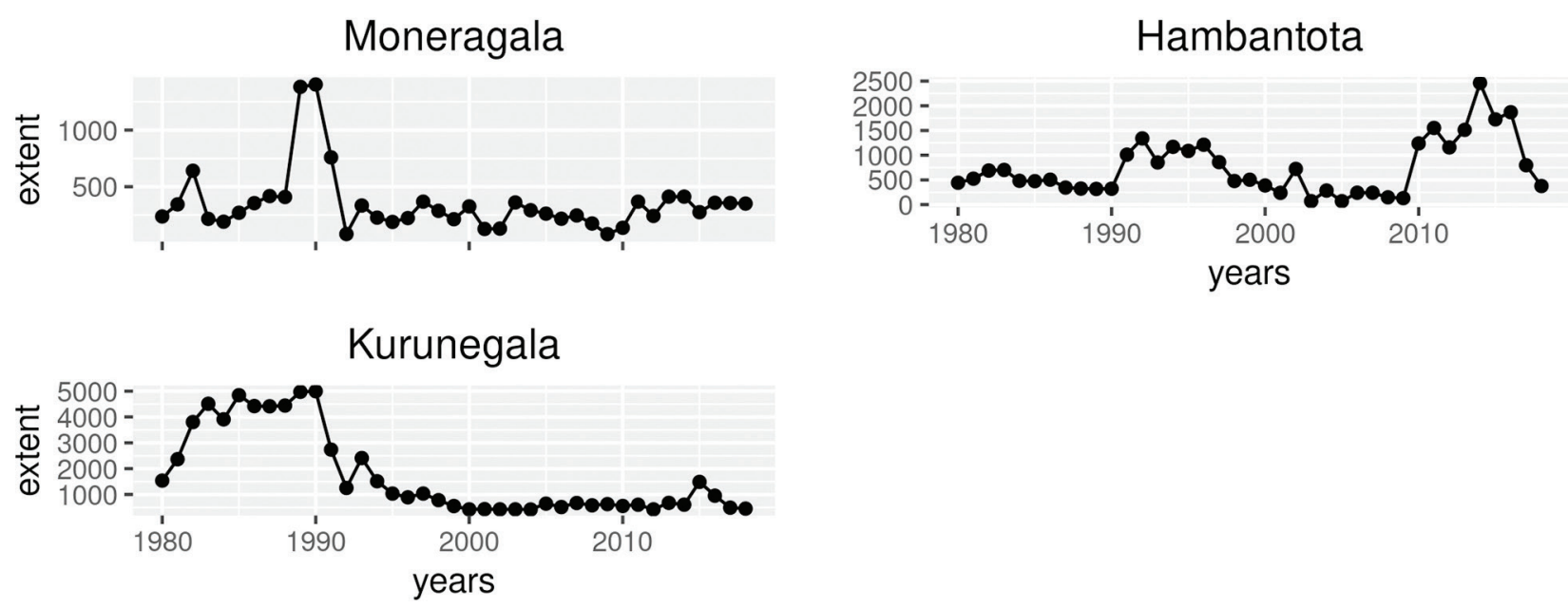

Figure A20. Green gram cultivated area (ha) - Yala season - irrigated 
Moneragala

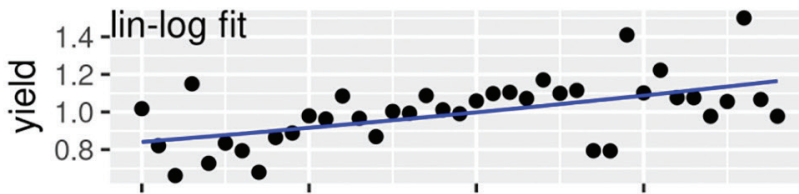

Kurunegala

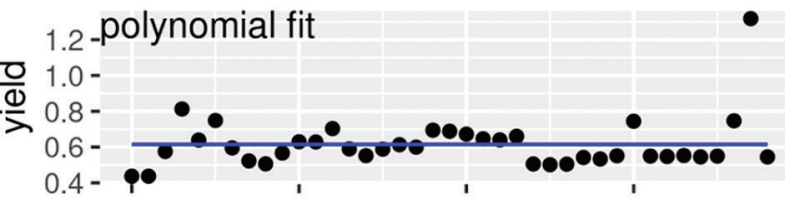

Puttalam

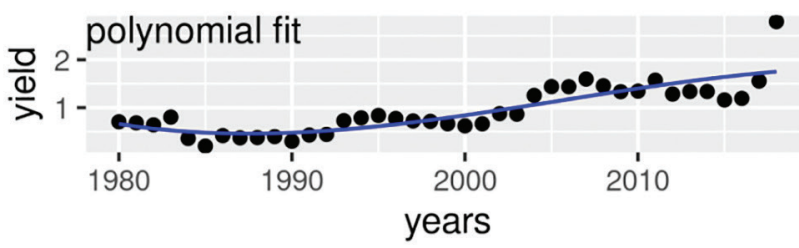

Hambantota

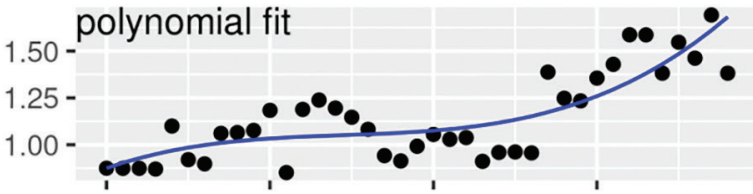

Anuradhapura

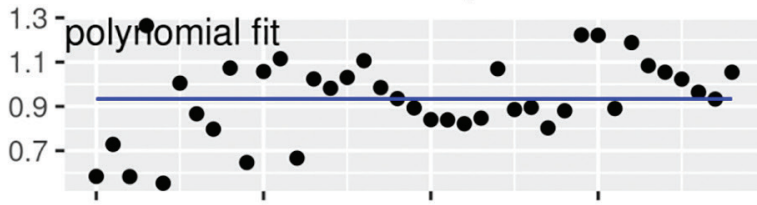

Ampara

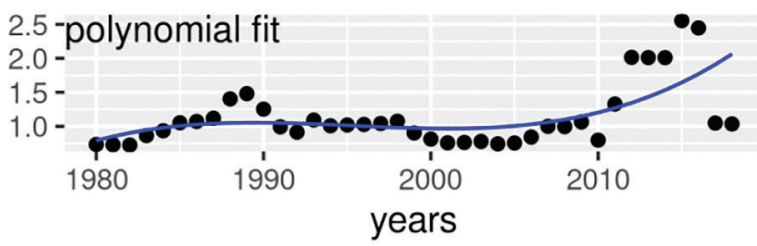

Figure A21. Green gram yield and trend line (t/ha) - Maha season - Irrigated
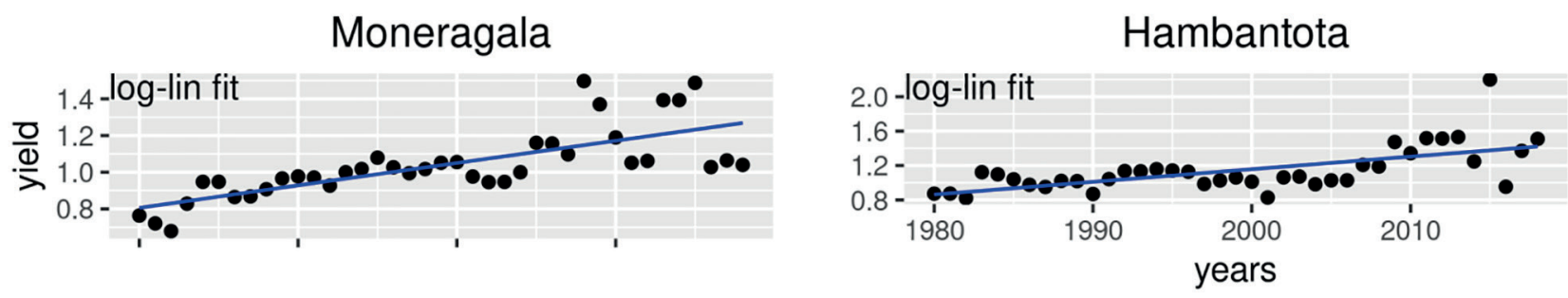

Kurunegala

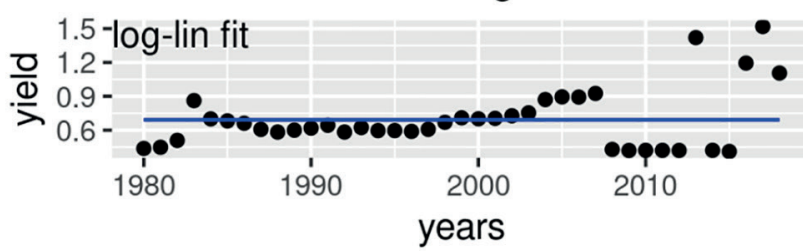

Figure A22. Green gram yield and trend line (t/ha) - Yala season - Irrigated 


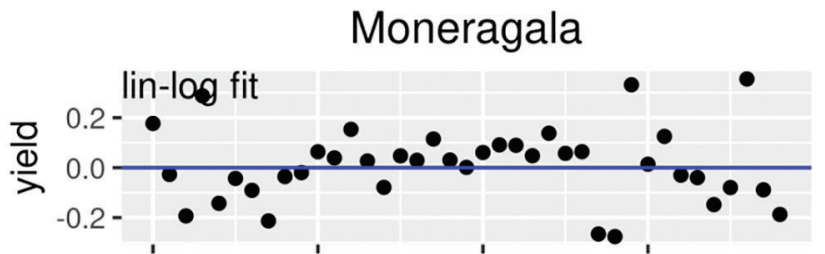

Kurunegala

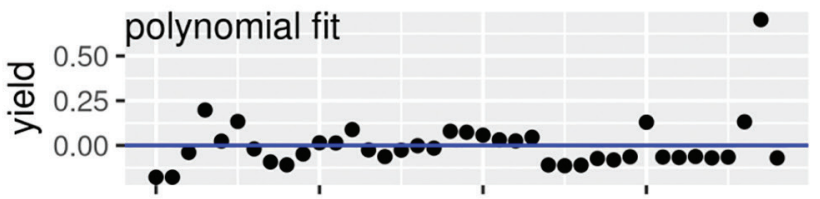

Puttalam

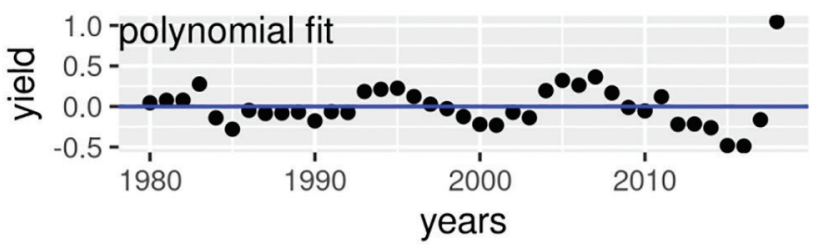

Hambantota

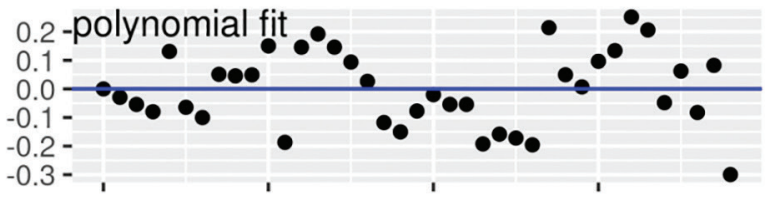

Anuradhapura

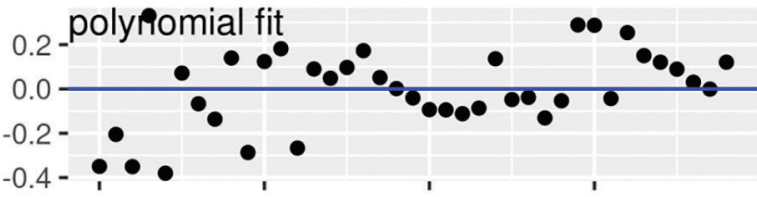

Ampara

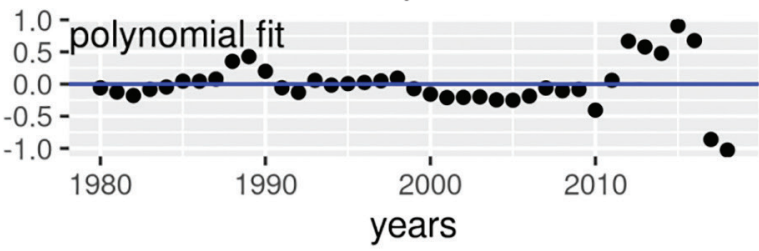

Figure A23. Green gram yield anomaly (t/ha) - Maha season - Irrigated
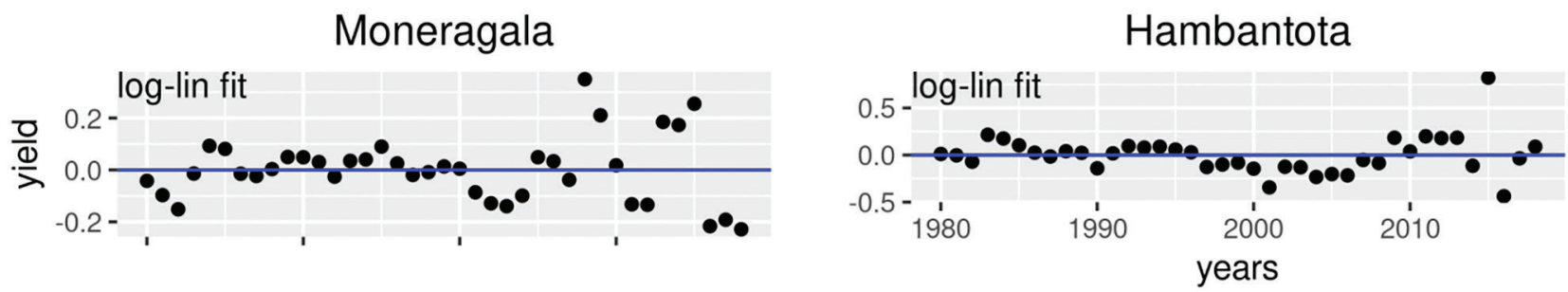

Kurunegala

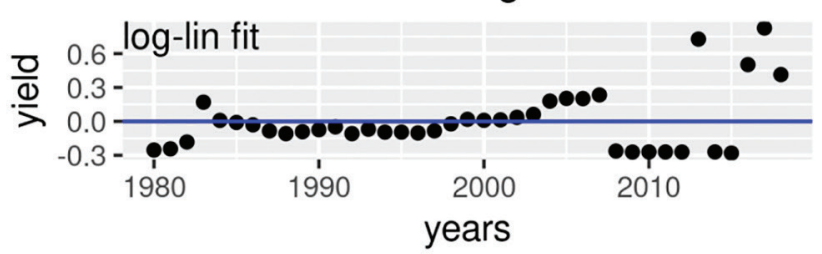

Figure A24. Green gram yield anomaly (t/ha) - Yala season - Irrigated 
Badulla

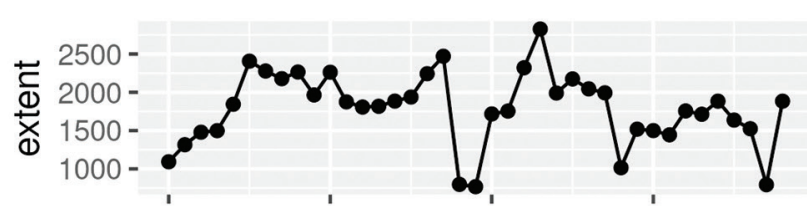

Nuwaraeliya

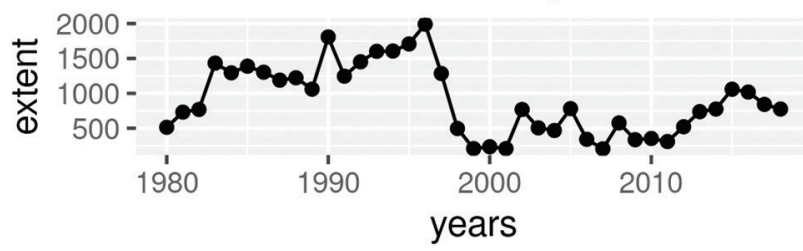

Jaffna

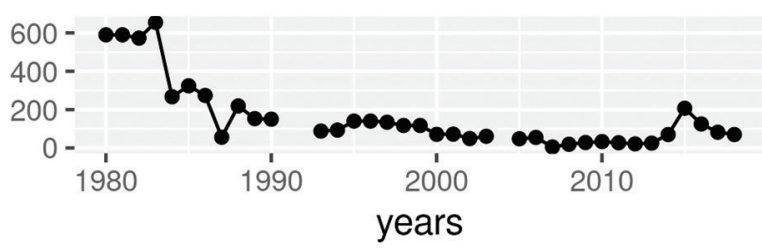

Figure A25. Potato cultivated area (ha) - Maha season - Irrigated

Figure A26. Potato cultivated area (ha) - Yala season - Irrigated
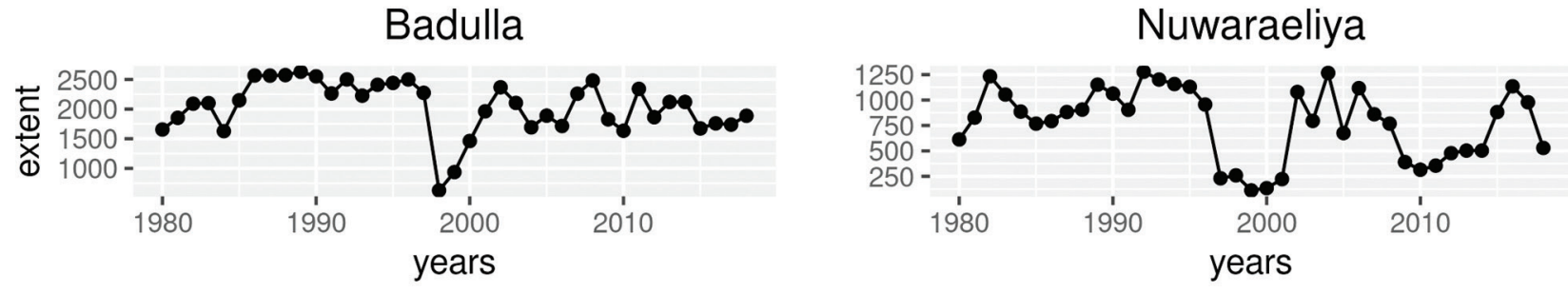

Badulla

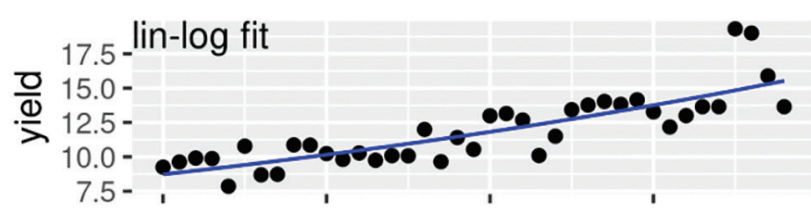

Nuwaraeliya

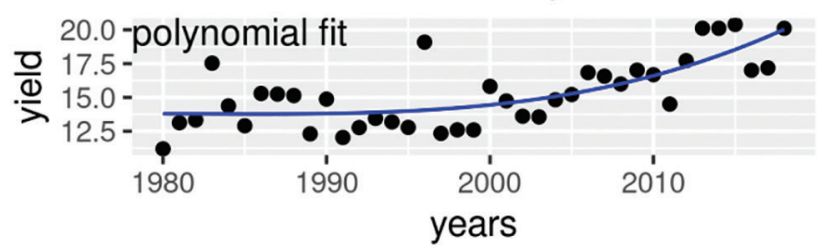

Jaffna

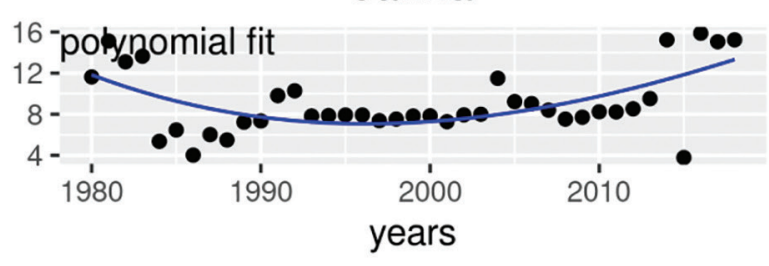


Badulla

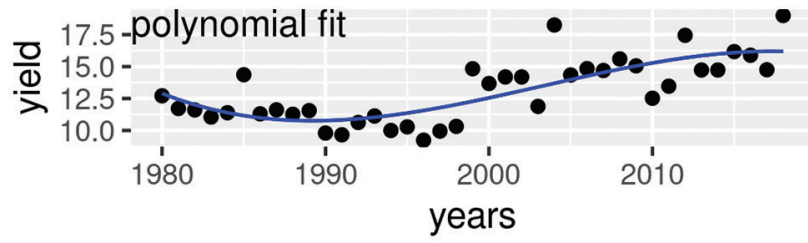

Nuwaraeliya

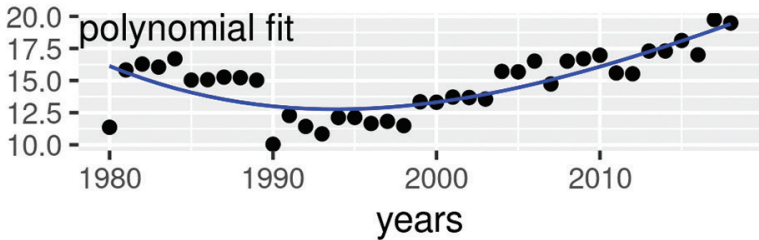

Figure A28. Potato yield and trend line (t/ha) - Yala season - Irrigated

Badulla

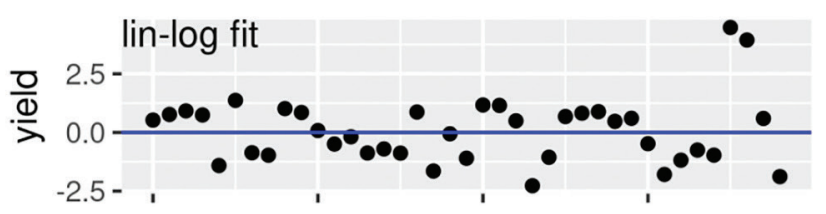

Nuwaraeliya

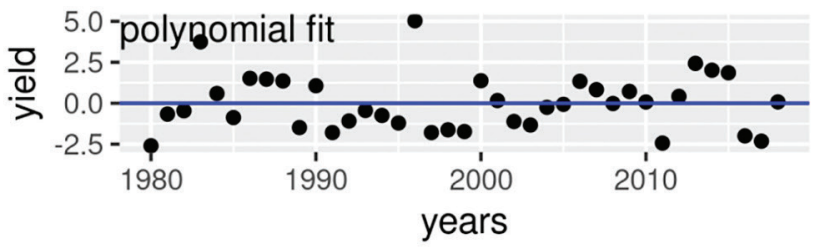

Jaffna

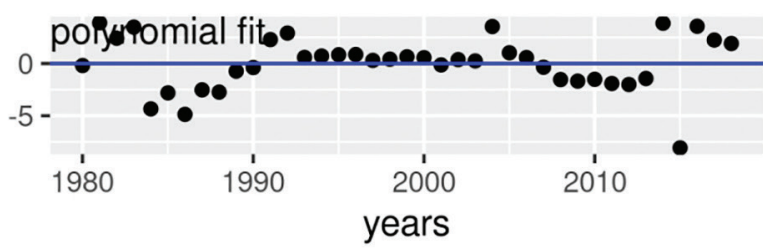

Figure A29. Potato yield anomaly (t/ha) - Maha season - Irrigated

Badulla

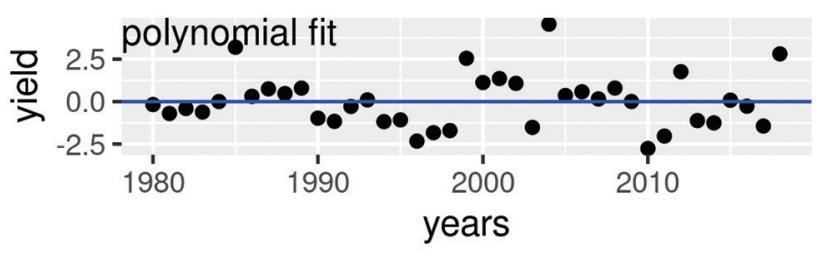

Nuwaraeliya

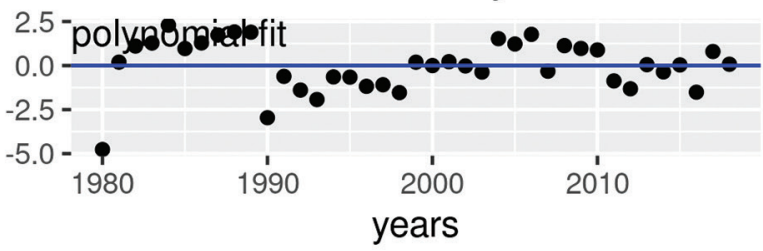

Figure A30. Potato yield anomaly (t/ha) - Yala season - Irrigated 
Anuradhapura

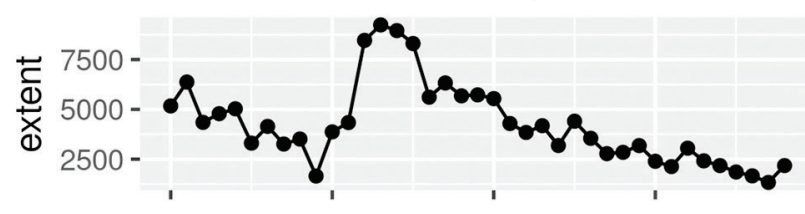

Kurunegala

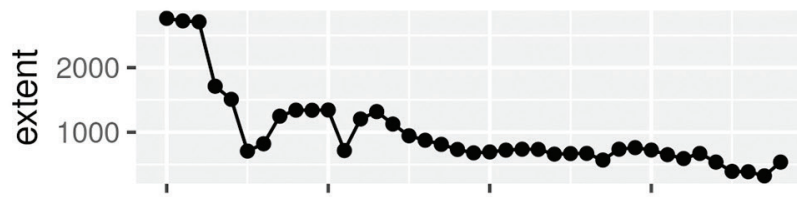

Moneragala

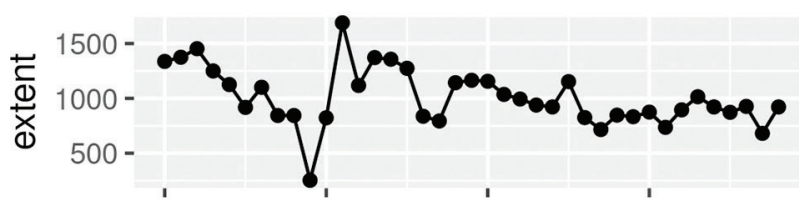

Ampara

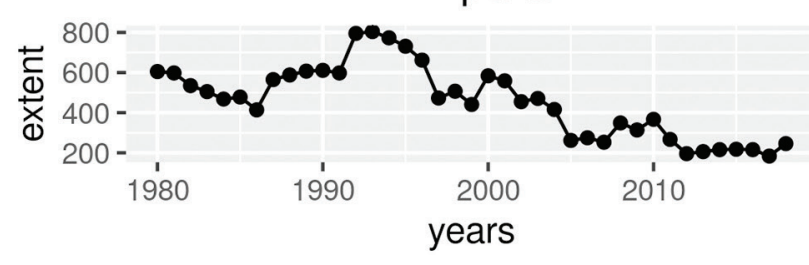

Jaffna

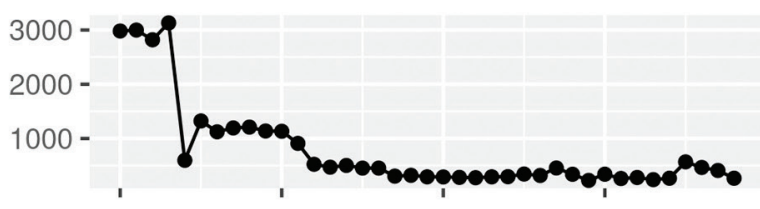

Badulla

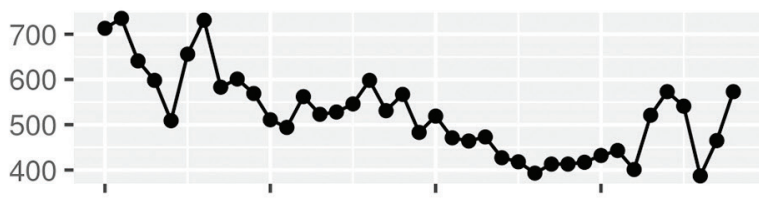

Hambantota

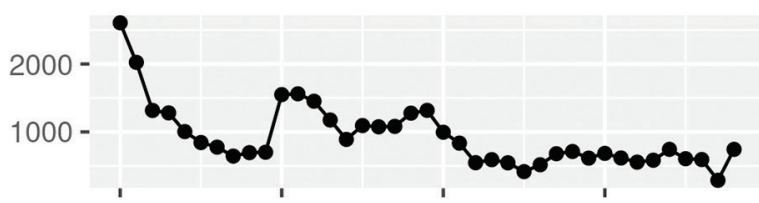

Puttalam

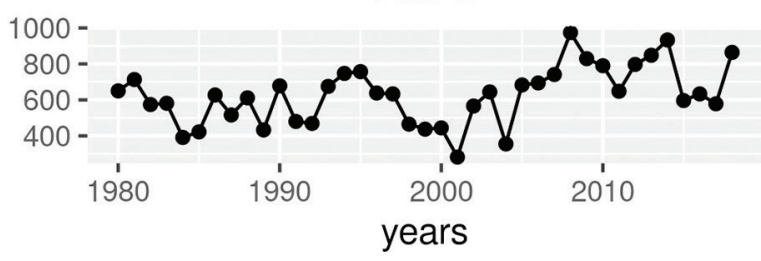

Figure A31. Chilli cultivated area (ha) - Maha season - Irrigated 
Puttalam

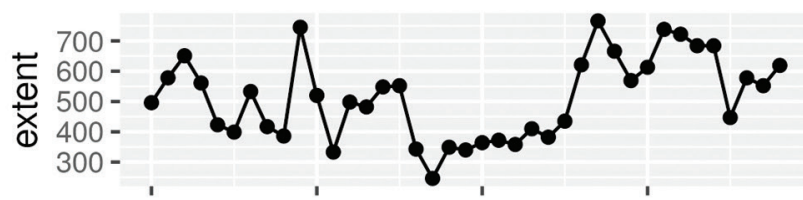

Matale

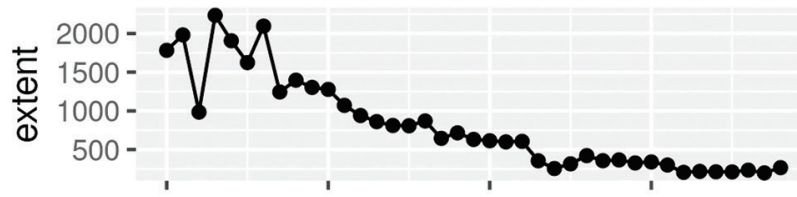

Jaffna

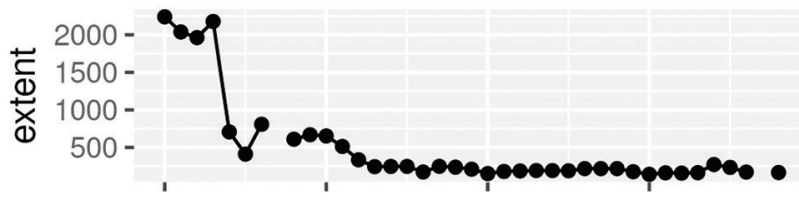

Hambantota

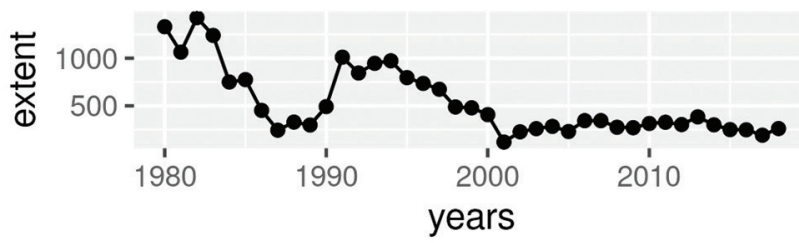

Anuradhapura

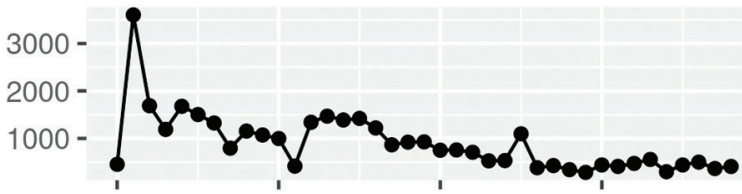

Kurunegala

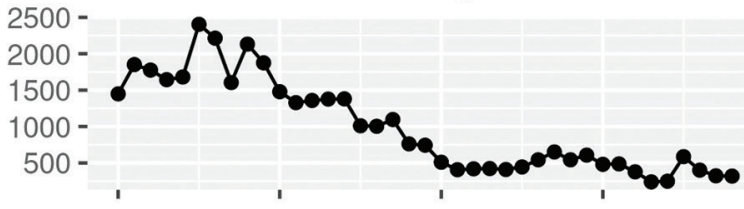

\section{Badulla}

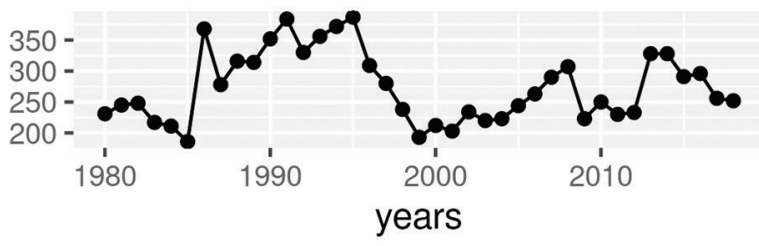

Figure A32. Chilli cultivated area (ha) - Yala season - Irrigated 
Anuradhapura

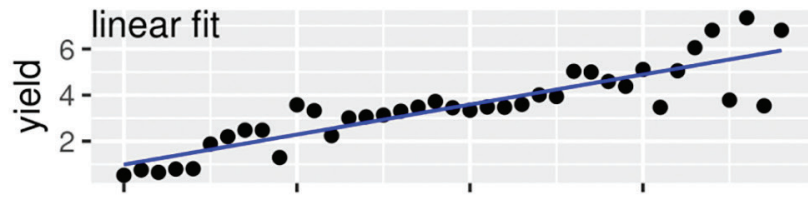

Kurunegala

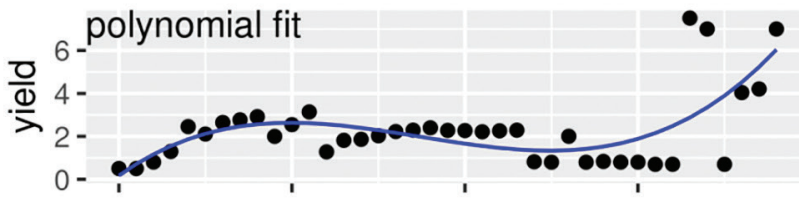

Moneragala

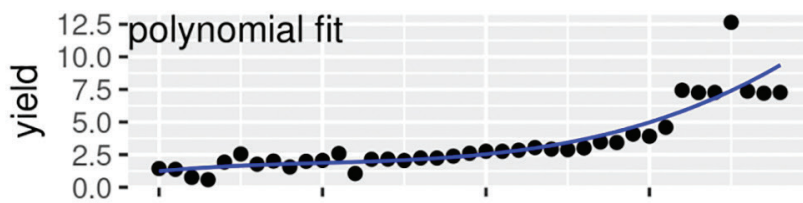

Ampara

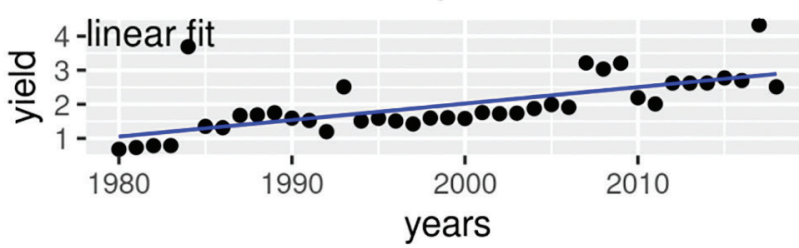

Jaffna

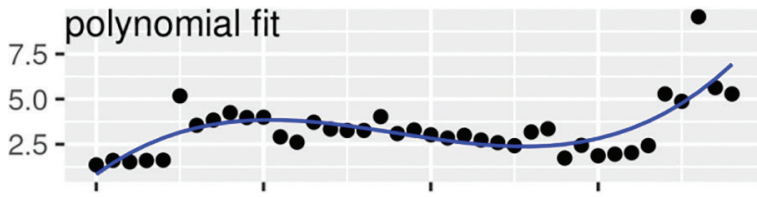

Badulla

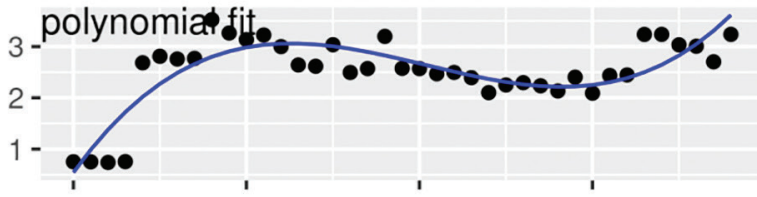

Hambantota

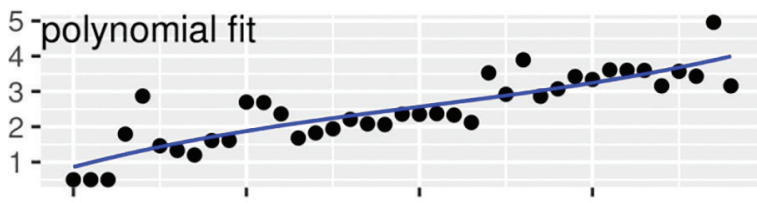

Puttalam

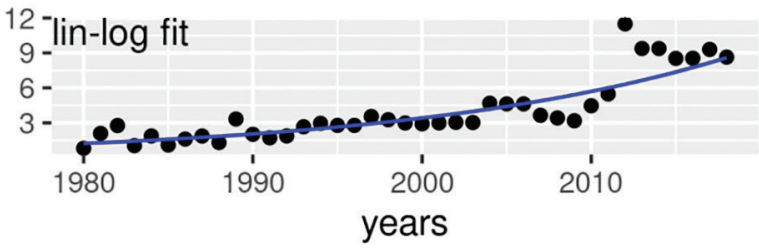

Figure A33. Chilli yield and trend line (t/ha) - Maha season - Irrigated 
Puttalam

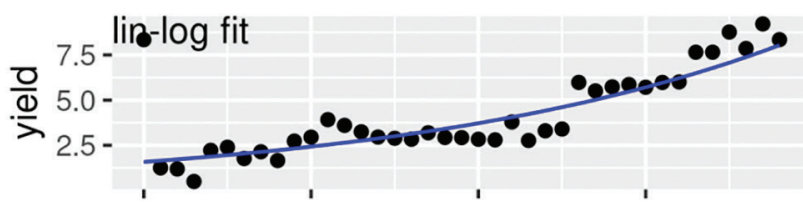

Matale

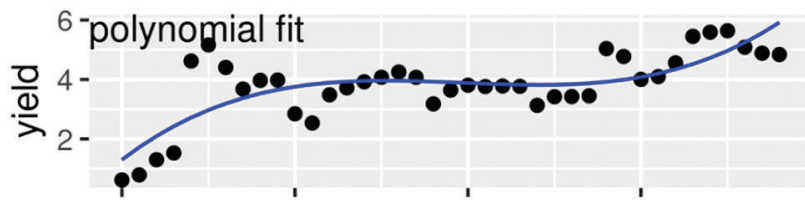

Jaffna

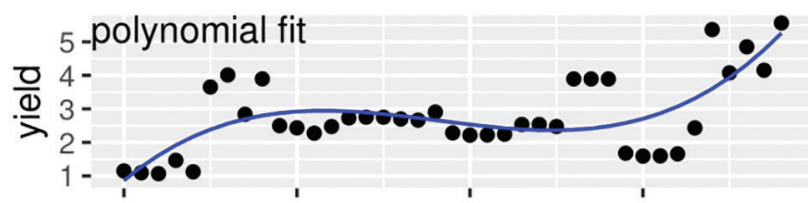

Hambantota

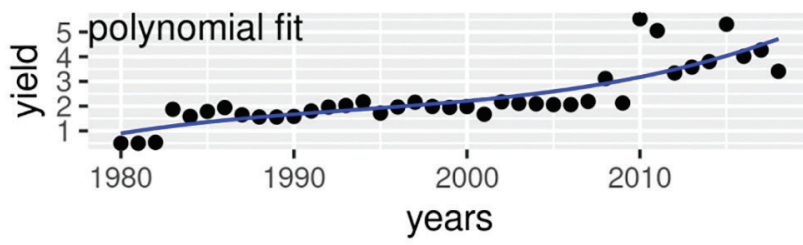

Anuradhapura

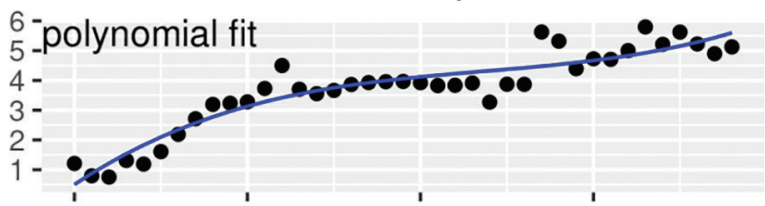

Kurunegala

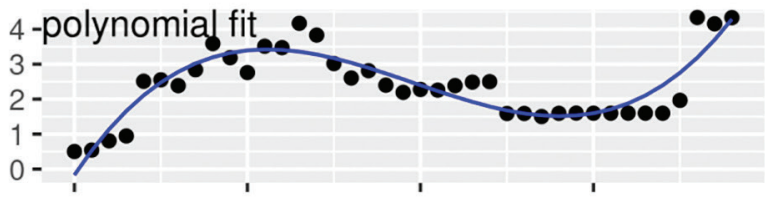

Badulla

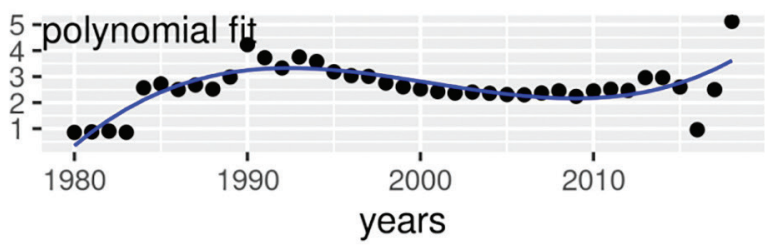

Figure A34. Chilli yield and trend line ( $t /$ ha) - Yala season - Irrigated 
Anuradhapura

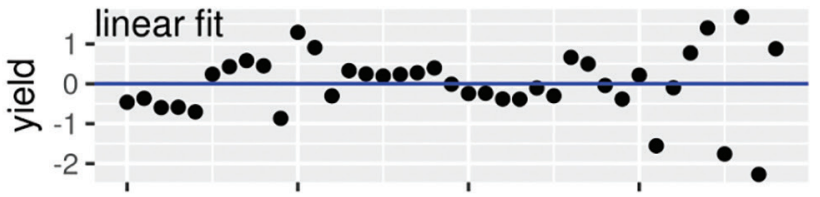

Kurunegala

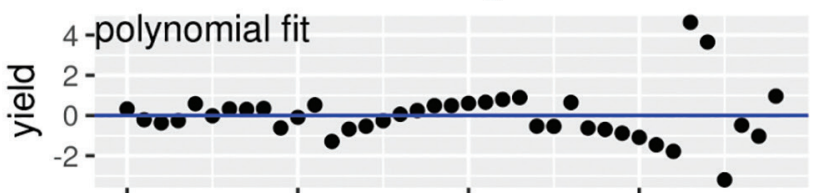

Moneragala

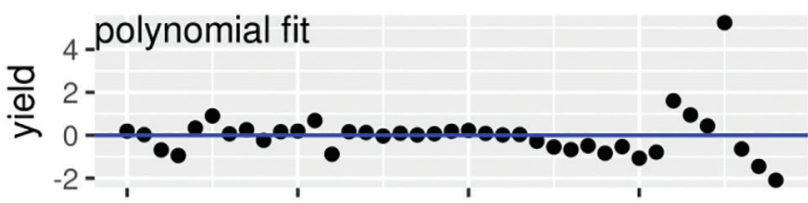

Ampara

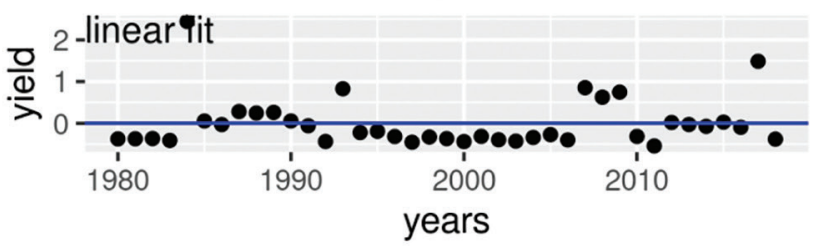

Jaffna

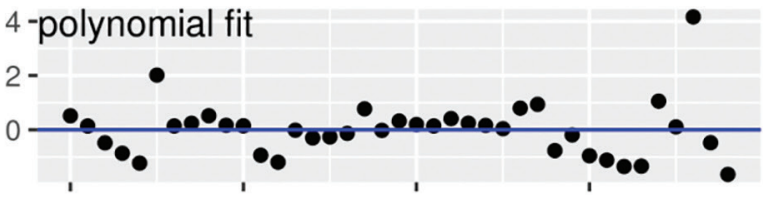

Badulla

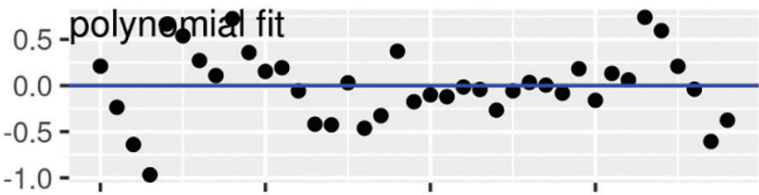

Hambantota

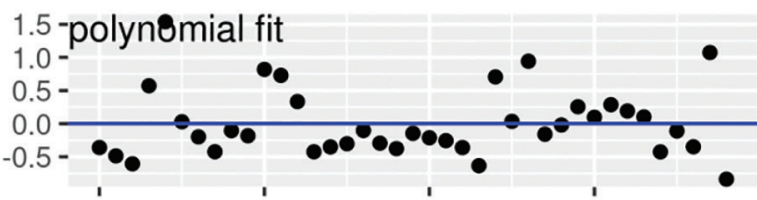

Puttalam

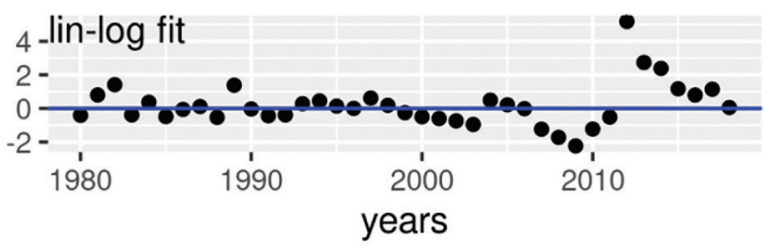

Figure A35. Chilli yield anomaly (t/ha) - Maha season - Irrigated 
Puttalam

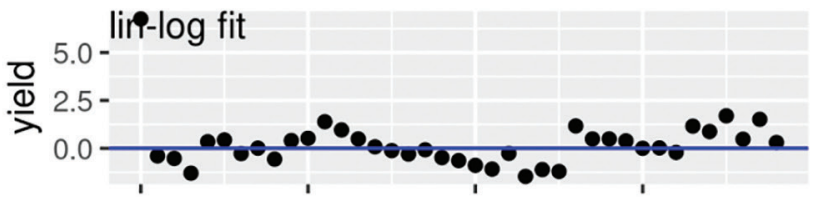

Matale

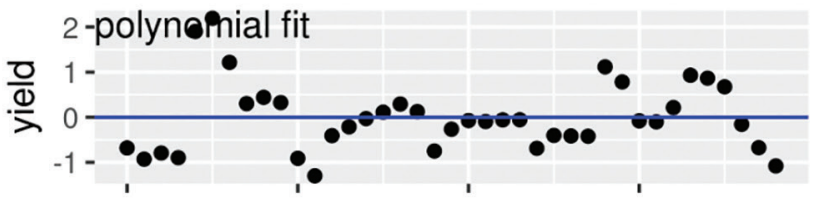

Jaffna

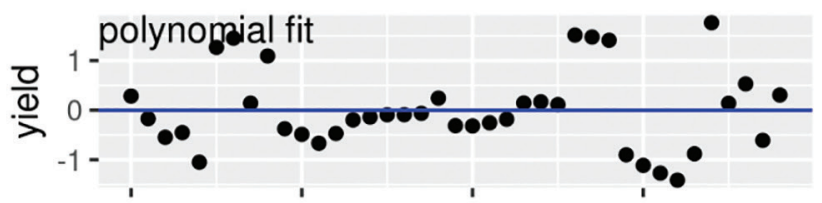

\section{Hambantota}

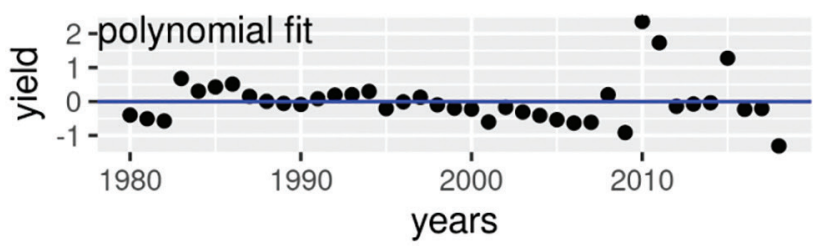

Anuradhapura

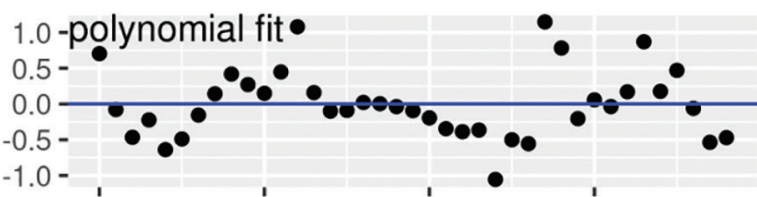

Kurunegala

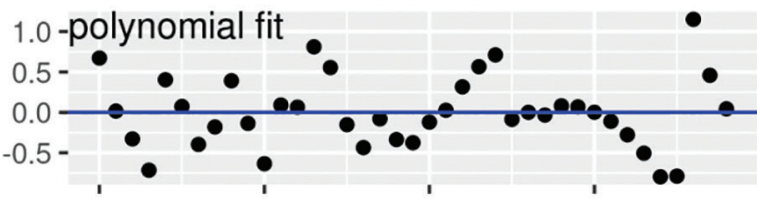

Badulla

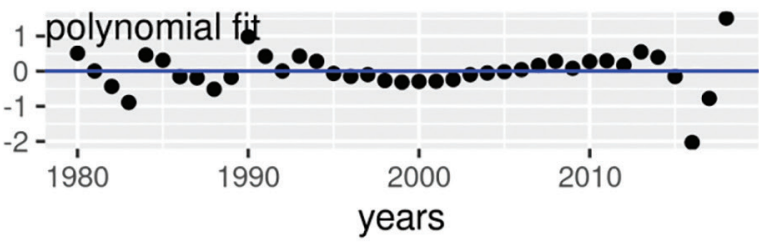

Figure A36. Chilli yield anomaly (t/ha) - Yala season - Irrigated 
The boundaries and names shown, and the designations used on this/these map(s) do not imply the expression of any opinion whatsoever on the part of FAO concerning the legal status of any country, territory, city or area or of its authorities, or concerning the delimitation of its frontiers and boundaries. Dashed lines on maps represent approximate border lines for which there may not yet be full agreement. 



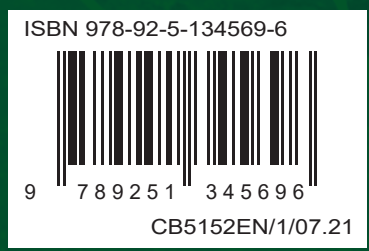

